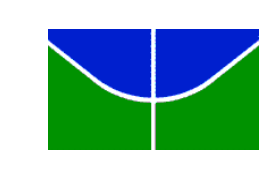

Universidade de Brasília

Instituto de Artes - Departamento de Música

Programa de Pós-Graduação em Música

JOSILAINE DE CASTRO GONÇALVES

“TODO MUNDO APRENDE, TODO MUNDO ENSINA": O PROJETO MULTIPLICADORES DO INSTITUTO BATUCAR 
JOSILAINE DE CASTRO GONÇALVES

\title{
“TODO MUNDO APRENDE, TODO MUNDO ENSINA": O PROJETO MULTIPLICADORES DO INSTITUTO BATUCAR
}

\begin{abstract}
Dissertação apresentada ao Programa de PósGraduação "Música em Contexto" do Instituto de Artes da Universidade de Brasília, na área de concentração, Concepções e Vivências no ensino e aprendizagem da música para obtenção do título de mestre.
\end{abstract}

Orientadora: Prof ${ }^{a}$. Dra. Maria Cristina de Carvalho Cascelli de Azevedo

\section{Brasília}


Josilaine de Castro Gonçalves

\title{
“TODO MUNDO APRENDE, TODO MUNDO ENSINA": O PROJETO MULTIPLICADORES DO INSTITUTO BATUCAR
}

\author{
Comissão examinadora \\ Prof ${ }^{a}$. Dra. Maria Cristina de Carvalho Cascelli de Azevedo- PPG/MUS/UnB \\ (Orientadora) \\ Prof $^{\mathrm{a}} \overline{\text { Dra. Delmary Vasconcelos de Abreu - PPG/MUS/UnB }}$
}

Prof $^{\text {a }}$. Dra. Cristiane Maria Galdino de Almeida - PPG/MUS/UFPE

Prof ${ }^{\mathrm{a}}$.Dra. Maria Isabel Montandon - PPG/MUS/UnB

(Suplente)

Brasília, 01 de dezembro de 2014. 


\section{AGRADECIMENTOS}

À minha prof ${ }^{a}$. Dra. Maria Cristina de Carvalho Cascelli de Azevedo, que com muita paciência, dedicação e profissionalismo me acompanhou em todo esse tempo. Agradeço as suas orientações e incentivo, pois foram valiosos e importantes e contribuíram significativamente para a realização dessa pesquisa.

A todos os professores do Departamento de Música da Universidade de Brasília (UnB). Aprendi muito nas disciplinas e nas convivências diárias com todos vocês.

A todos os colegas do mestrado, aos colegas do grupo de pesquisa: Larissa, Guilherme, Verônica, Lisette. À amiga Maria Deborah, pela amizade, companheirismo e conhecimentos compartilhados.

Aos funcionários do PPG/MUS que sempre se mostraram dispostos a me auxiliar

À CAPES, pelo apoio financeiro

Ao meu esposo Gleidistone Rodrigues, pela paciência, carinho e compreensão nas ausências necessárias para a dedicação a este trabalho

À minha mãe Antônia Selma, ao meu pai Sebastião Gonçalves, à minha avó Maria Eunice, à minha sogra Aldenora, às minhas cunhadas Gleidislane e Aline, que estiveram à disposição para cuidar do meu filho para que eu pudesse realizar essa pesquisa

Ao Instituto Batucar, que generosamente abriu as portas do seu espaço para a pesquisa.

Agradeço a Deus pela oportunidade de ter chegado até aqui, por ter me dado forças para continuar nos momentos mais difíceis e superar muitos obstáculos encontrados no caminho do mestrado. 
"Ninguém é tão grande que não possa aprender, nem tão pequeno que não possa ensinar"

(Esopo) 


\section{RESUMO}

Resumo: Os projetos sociais têm se constituído como espaço de práticas musicais e de ensino e aprendizagem da música. Neles, o aprender e o aprender a ensinar se confundem com o desenvolvimento musical dos sujeitos, com a sua formação e inclusão social. No Distrito Federal (Brasil), o Instituto Batucar é um exemplo de projeto social onde há o ensino e a aprendizagem musical e constitui o lócus desta pesquisa. Nesse contexto, esta dissertação visa compreender a atuação dos multiplicadores no projeto social Instituto Batucar. Descrever as práticas musicais desenvolvidas no Instituto; identificar as estratégias pedagógico-musicais dos multiplicadores e conhecer como eles percebem sua atuação no projeto são os objetivos específicos desta pesquisa. No Distrito Federal (DF), o Instituto Batucar visa à transformação e inclusão social por meio da prática musical, especificamente, a percussão corporal. A instituição desenvolve um projeto de multiplicadores que capacita os participantes do projeto como monitores e educadores. Nesse contexto, foram realizadas observações participantes, entrevistas semiestruturadas individuais e coletivas (como grupo focal) caracterizando um estudo de caso. A fundamentação teórica utiliza o conceito de educador social segundo Gohn (2010) e Freire (2011) para pensar a atuação do multiplicador no IB. O conceito de educação não formal, conforme Gohn (2010) e Gadotti (2005) orientam a reflexão sobre o processo educativo em projetos sociais. Na área da Educação Musical, Kleber (2006), Almeida (2005), Hikiji (2006) e Cruvinel (2005) complementam o diálogo com a literatura que discute projeto social e música. Com base na voz dos multiplicadores que atuam no Instituto Batucar, os resultados revelam que a sua atuação acontece na prática com o compartilhamento de experiências no projeto, em que o saber é construído, organizado e mediado por meio das interações sociais, sem desconsiderar as referências e influências adquiridas ao longo da trajetória dos jovens educadores.

Palavras-Chave: Projetos sociais; educação não formal, multiplicadores, práticas pedagógico- musicais. 


\begin{abstract}
Abstract: Social projects have become spaces for musical practices, as well as for teaching and learning music. Within these spaces, learning and learning how to teach are intertwined with the participants' musical development, with their training and social inclusion. In the Federal District (Brazil), the Batucar Institute is an example of a social project where teaching and musical learning occurs, and it is also the focus of this study. Within this context, this dissertation aims to understand the work of the "multiplying agents" as facilitators within the social project of the Batucar Institute, to describe and analyze musical practices developed at the Batucar Institute, to identify the multiplying agents' musicalpedagogical strategies and to discover how they perceive their actions within the project are the specific objectives of this study. In the Federal District (DF), the Batucar Institute aims to promote social transformation and inclusion throughout musical practice, more specifically through body percussion. The institution develops multiplying agents' project which trains the projects' participants enabling them to become teaching assistants and educators. In this context, participative observations were made, as well as individual and collective semi structured interviews (such as focal groups), characterizing this as a case study. The theoretical grounding uses concepts of the social educators Gohn (2010) and Freire (2011) to reflect upon the multiplying agents' role at the Batucar Institute. The concept of non-formal education, according to Gohn (2010) and Gadotti (2005), guide the reflexion concerning the educational process in social projects. In the field of musical education, Kleber (2006), Almeida (2005), Hikiji (2006) and Cruvinel (2005) are used to compliment the dialogue with the literature that discusses social projects and music. According to the multiplying agents' testimonials, the results reveal that their work occur in practice when they share experiences in the project, where knowledge is constructed, organized and mediated throughout social interactions, without disconsidering the references and influences acquired during the educators' experiences in their professional path.
\end{abstract}

Keywords: Social Projects; non-formal education, multiplying agents, pedagogical musical practices. 


\section{LISTA DE FIGURAS}

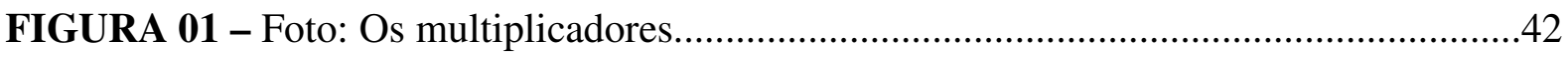

FIGURA 02 - Triângulo da Percussão Corporal.....................................................................64

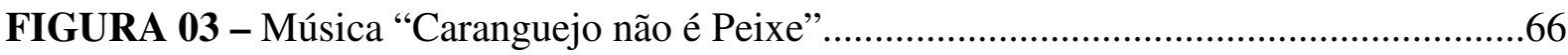

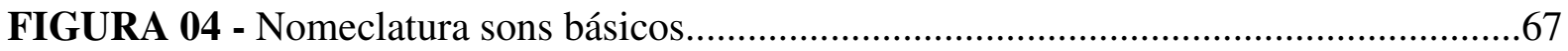

FIGURA 05 - Foto: A Roda de Percussão Corporal.................................................................68

FIGURA 06 - Foto: Aprendizado do acordes das aulas de teoria musical..............................76

FIGURA 07 - Sons corporais e sua representação musical....................................................79

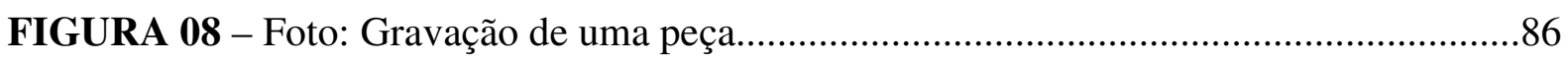




\section{LISTA DE QUADROS}

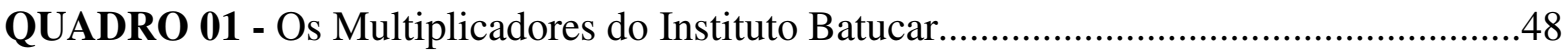

QUADRO 02 - Dias e duração das observações participantes ...............................................50

QUADRO 03 - Datas, participantes e duração das entrevistas.............................................53

QUADRO 04 - Datas, participantes e duração dos Grupos Focais .........................................53 


\section{LISTA DE ABREVIATURAS E SIGLAS}

CAPES - Coordenação de Aperfeiçoamento de Pessoal de Nível Superior.

CEF 113/Rec. Emas - Centro de Ensino Fundamental 113/Recanto das Emas.

DIEESE - Departamento Intersindical de Estatística e Estudos Socioeconômicos

ECA - Estatuto da Criança e do Adolescente

EMB - Escola de Música de Brasília

IB - Instituto Batucar

ONG - Organização Não Governamental

OSCIP - Organização da Sociedade Civil de Interesse Público

UNESCO - Organização das Nações Unidas para a Educação, a Ciência e a Cultura, em inglês "United Nations Educational, Scientific and Cultural Organization”

UNICEF - Fundo das Nações Unidas para a Infância, em inglês "United Nations Children's Fund" 


\section{SUMÁRIO}

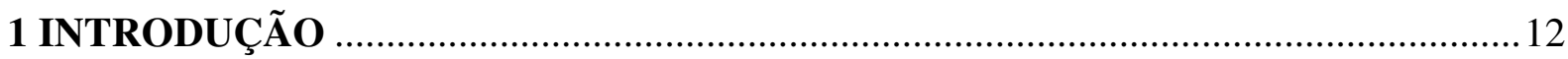

2 PROJETO SOCIAL E EDUCAÇÃO MUSICAL ....................................................... 18

2.1 PROJETO SOCIAL, ONGs e OSCIPs: UM CONCEITO COMUNITÁRIO E

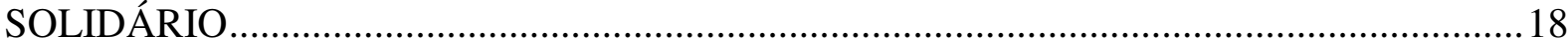

2.2 A MÚSICA EM PROJETOS SOCIAIS: AS PESQUISAS ….........................................22

3 EDUCAÇÃO NÃO FORMAL E O EDUCADOR SOCIAL ...................................... 31

3.1 EDUCAÇÃO NÃO FORMAL - UM CONCEITO EM CONSTRUÇÃO .........................31

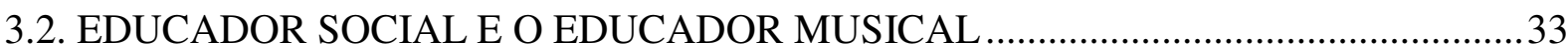

3.3 A DIVULGAÇÃO E SOCIALIZAÇÃO DE SABERES: O PAPEL DOS

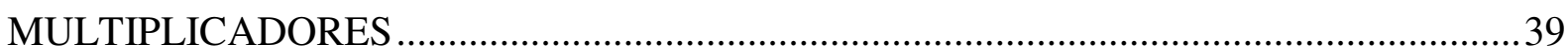

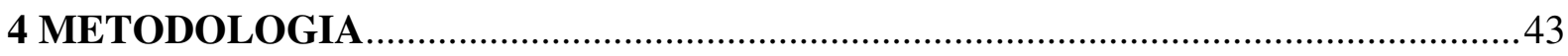

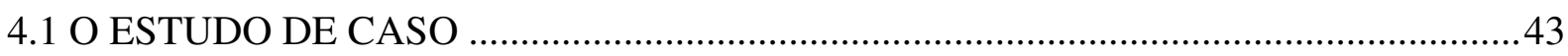

4.2 A EXPERIÊNCIA DE CAMPO NO BATUCAR.........................................................47

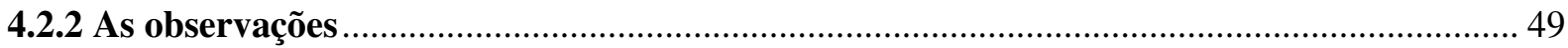

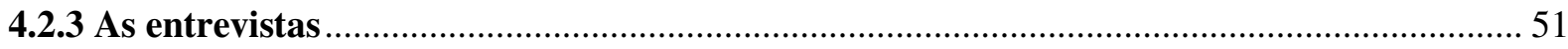

4.3 PROCEDIMENTOS DE ORGANIZAÇÃO E ANÁLISE DE DADOS ...........................54

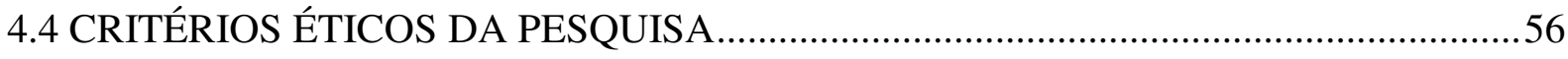

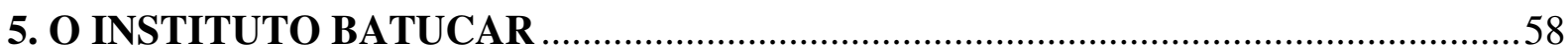

5.1 A INSTITUIÇÃO: A MÚSICA NO CORPO PARA TRANSFORMAR..........................58

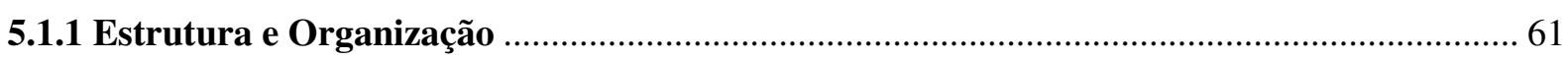

5.2 PRINCÍPIOS PEDAGÓGICO-MUSICAIS: CORPO, VOZ E MOVIMENTO ................63

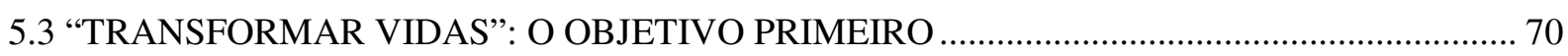

5.4 AUTOESTIMA: “ELES PODEM ESTAR ALI”........................................................ 71

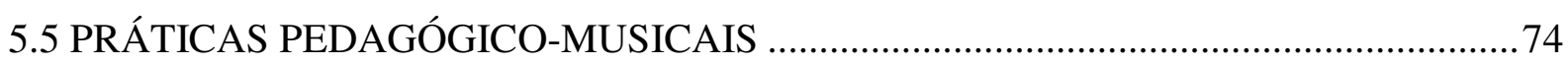

5.6 OS MULTIPLICADORES - APRENDER A SER EDUCADOR …................................. 81

5.6.1 “Ôxe aprende demais moço!”’: Aprender e ensinar na prática ................................ 83

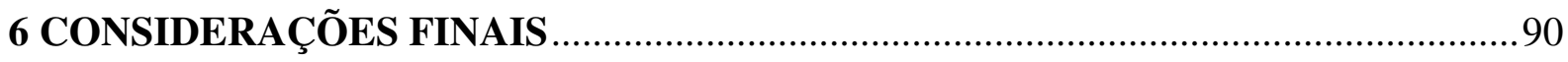

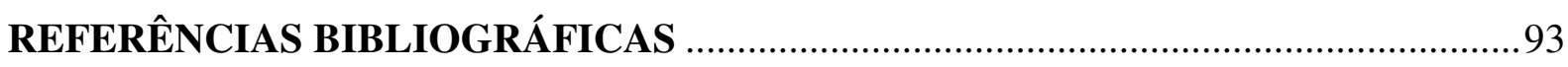

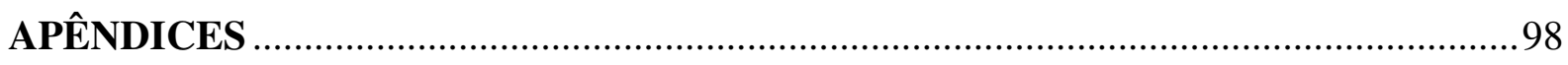

APÊNDICE A - Carta de apresentação de pesquisadora ..............................................99

APÊNDICE B - Carta de solicitação de autorização para observação e filmagem ....... 100

APÊNDICE C - Carta de cessão de direito ............................................................. 101

APÊNDICE D - Autorização de participação de menor em entrevista .......................... 102 
APÊNDICE E - Roteiro para entrevista (Coordenador) ............................................ 103

APÊNDICE F - Roteiro para entrevista (Coordenadora Pedagógica) ........................... 105

APÊNDICE G - Roteiro para entrevista (Administrador) ........................................... 107

APÊNDICE H - Roteiro para entrevista (Educadores de música) .............................. 108

APÊNDICE I - Roteiro para entrevista focal com os Multiplicadores do Instituto

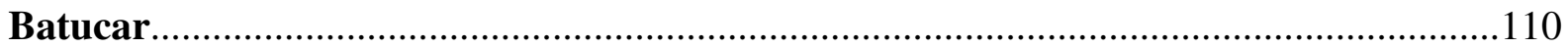




\section{INTRODUÇÃO}

$\mathrm{Na}$ atualidade, a música tem tido uma participação relevante no contexto da educação não formal, devido, principalmente, à sua dimensão social, à sua receptividade, às suas características de desenvolvimento pessoal e motivação e à sua interface com diferentes áreas da atuação social. Nesse espaço educacional, tenho atuado como profissional e refletido sobre os processos de ensino e aprendizagem musical e sobre a formação de educadores. Minhas experiências pessoais como instrutora socioeducativa nos projetos sociais Fenações (Instituição Social) e Projeto Ciranda (Universidade Católica de Brasília - UCB) convergem para essas questões. Esses projetos atendem crianças e adolescentes de risco e vulnerabilidade social e exploram a música como uma das atividades de formação e transformação social. Na minha experiência pessoal, a seleção de educadores é flexível e a formação acadêmica não é determinante. $\mathrm{O}$ educador pode ter formação de nível médio e, para atuar com música, é valorizada a prática musical, ou seja, saber tocar ou cantar. Portanto, é comum o educador não ter experiência pedagógica e sua formação ocorrer na prática. Nesse contexto, o primeiro contato é desafiador e a interação com os alunos é construída no dia a dia. Nesse sentido, ao atuar como educadora em projetos sociais, deparei-me com algumas situações inesperadas como: 1) diversidade do público-alvo em termos de faixa etária, formação e interesse; 2) grande rotatividade dos adolescentes e jovens nas atividades; 3) indisciplina e falta de formação de hábitos e atitudes; 4) diferenças sociais, culturais e de valores entre os profissionais e o público-alvo; 5) não formação do educador para atuar nesse contexto; 6) diversidade de atribuições que são exigidas dos educadores; 7) necessidade de desenvolver saberes e competências associados a relações interpessoais.

Tanto no projeto Fenações como no projeto Ciranda, trabalhei com crianças e adolescentes entre 06 e 15 anos de idade, oriundos do Recanto das Emas, localizado no Distrito Federal. Em algumas situações, essa diversidade de faixa etária ajudava, mas em outras, dificultava minha atuação como educadora. Sob tais circunstâncias, aprendi a ensinar com as dificuldades encontradas, a lidar com comportamentos diferenciados entre os alunos e a adequar interesses e atividades para uma criança de 06 anos ou para um adolescente, por exemplo. Entender os alunos de uma turma tão diferenciada levou-me a observar as situações e aprender com elas no cotidiano.

No Projeto Ciranda, a rotatividade dos alunos em música e em outras atividades oferecidas era frequente. Os alunos tinham aula de música em uma semana e, na outra, aula de informática, acompanhamento pedagógico ou esportes. Essa situação me obrigou a adaptar 
os conteúdos a serem ensinados ao tempo disponível, preocupando-me como o aluno poderia aprender em uma semana. Para tanto, desenvolvi algumas estratégias de ensino em que o aluno pudesse aprender em duas aulas alguma música ou algum exercício que seria simples, fácil e que ele pudesse desenvolver alguma habilidade em pouco tempo de prática.

Nos dois projetos encontrei alunos interessados em aprender música, alunos que estavam inscritos no projeto porque os pais os colocaram e outras crianças encaminhadas por meio de serviços sociais. Estas não tinham pais e eram moradoras de rua. A origem das crianças exigia a formação e a aprendizagem de hábitos antes de ensinar música: orientar sobre a higiene pessoal; mostrar como se comportar no projeto; orientar sobre atitudes e respeito aos educadores e aos colegas.

Nas aulas de música, eram também trabalhados os valores humanos por meio das rodas de conversas. Nelas se desenvolvia uma comunicação entre os alunos e eu percebia que eles precisavam desse momento, pois eles desejavam não apenas aprender algo, mas gostavam de conversar sobre sua vida, queriam ser mais próximos do educador e, assim, nesses momentos, foram surgindo temas como amizade, religião, drogas, sexo. A partir desses temas, comecei a selecionar e trazer para as aulas músicas que abordavam esses assuntos. Por meio dessa estratégia, comecei a perceber que os alunos passaram a se interessar mais pelas aulas de música, começaram a se expressar melhor e a se comportar de forma adequada ao local. Partindo do interesse dos alunos, comecei a ensaiá-los para apresentações no próprio projeto, a fim de que pudessem gostar ainda mais de estudar e fazer música. A ideia foi aprovada pela coordenação e pude desenvolver melhor um trabalho com esse público que, até então, estava ali, principalmente, para preencher o tempo ocioso.

Ao atuar como instrutora socioeducativa, percebi que, como eu, os educadores não são formados ou capacitados para atuar nos projetos sociais: a formação acontece na prática, no cotidiano, nas situações, nas dificuldades e soluções vivenciadas. A formação em contexto me fez aprender a encontrar soluções para os problemas e, principalmente, aprender com os alunos, que me mostraram os caminhos e a forma de educá-los.

Dentre as dificuldades encontradas, as atribuições confiadas a mim nos projetos eram variadas e desafiadoras: além de dar aula de música, muitas vezes, eu tinha que agendar passeios para os alunos, organizar eventos e atividades recreativas no projeto, coordenar, responsabilizar-me pela compra, entrada e saída de instrumentos e agendar salas. Algumas dessas atribuições eram constantes e as atividades administrativas pareciam mais importantes para o projeto do que a responsabilidade de ensinar música. Contudo, nessa experiência, 
compreendi que atuar em um projeto social envolve um comprometimento com a coletividade, o que vai além da atividade de ensinar música.

Ainda assim, para melhor desenvolver saberes e competências musicais e melhorar o desempenho dos alunos, comecei a criar e organizar oficinas de música em que somente os alunos que quisessem aprender música participassem. As oficinas começaram a acontecer e, com o tempo, se destacaram do grupo. Essa experiência comprovou o interesse musical de parte dos alunos e demonstrou a capacidade, o potencial e a possibilidade de se desenvolver a prática musical nesse contexto socioeducativo.

Portanto, a minha atuação como instrutora socioeducativa e as dificuldades e incertezas encontradas me levaram a refletir sobre a atuação de educadores/instrutores em um projeto social. Como é a atuação de educadores em projetos sociais? Ela é considerada ideal e necessária? Que práticas musicais são desenvolvidas? Que estratégias musicais são utilizadas? Como os educadores/instrutores percebem sua atuação?

Diante desses questionamentos, procurei conhecer projetos sociais bem sucedidos que desenvolvessem um trabalho musical no Distrito Federal. No Recanto das Emas, o Instituto Batucar (IB) apresenta uma proposta singular de educação musical. O projeto atende cerca de 100 crianças entre 06 e 17 anos, moradores da comunidade, e desenvolve aulas de música com foco na percussão corporal, além do ensino de canto e instrumentos como o violão, o violino e o violoncelo. No IB ainda há o projeto "Multiplicadores", ou seja, projeto com o objetivo de preparar alunos que se destacam como instrutores ou monitores, para atuar nas aulas de música e divulgar a percussão corporal. Nesse projeto, os alunos são incentivados a serem monitores nas aulas. Eles são responsáveis pela organização do espaço e dos instrumentos e pela aprendizagem de outros alunos no IB. Eles são convidados, semanalmente, depois das aulas, a participar das reuniões pedagógicas, chamadas de "mesa" e "gestão participativa", quando ocorre um momento de conversa que orienta a atuação dos multiplicadores. Nesse momento, por meio de conselhos e de orientações transmitidos pelo coordenador do IB, os próprios multiplicadores podem ser convidados a coordenar a reunião: há uma formação de liderança. O projeto "multiplicadores" promove a sustentabilidade da Instituição. A equipe de educadores do IB é composta por um coordenador, licenciado em música, uma coordenadora pedagógica, um administrador, uma pedagoga e um educador de música e 12 multiplicadores. É importante destacar que tanto o administrador, a pedagoga e o educador musical foram ex-alunos e multiplicadores do projeto. Eles desenvolvem atividades administrativas, pedagógico-musicais e atuam como músicos. O projeto social visa à promoção da transformação social por meio da música. Pelas características de sua proposta e 
do projeto multiplicadores, o IB foi escolhido como lócus desta pesquisa e a atuação dos multiplicadores no Instituto, como unidade de estudo.

Segundo o site da instituição, o IB é uma Organização não Governamental (ONG) registrada como Organização da Sociedade Civil de Interesse Público (OSCIP), com o objetivo de “[...] promover soluções de inclusão social através da arte, cultura e da educação, privilegiando os locais com baixo índice de desenvolvimento humano ${ }^{1}$." O projeto existe desde 2001, quando o coordenador foi convidado pela Igreja Presbiteriana de Brasília para ensinar música a crianças e adolescentes em situação de risco e vulnerabilidade social. O IB conta com parcerias públicas e privadas e desenvolve projetos visando a sua sustentabilidade e dos participantes. As atividades desenvolvidas no projeto social variam entre aulas de música, reuniões pedagógicas, ensaios para apresentações, grupo de performance e saraus préagendados. A qualidade e a originalidade do trabalho musical têm gerado a participação do grupo em apresentações culturais no Distrito Federal e em outros estados.

No âmbito do IB, a estrutura e a organização das atividades dependem da participação dos multiplicadores. O compromisso desses alunos com o projeto tem propiciado sua formação musical e sua iniciação profissional como músicos e educadores. Essa prática de compartilhamento de liderança e responsabilidades é uma característica do processo educativo na educação não formal. Segundo Gohn (2010), na educação não formal a metodologia é dinâmica e de caráter humanista, cujo objetivo é a formação da cidadania e o desenvolvimento da autonomia. Nesse sentido, é comum os participantes dos projetos se tornarem multiplicadores, monitores ou educadores, reproduzindo a metodologia aprendida.

Considerando a minha experiência formativa como instrutora socioeducativa e o projeto multiplicadores do IB, esta pesquisa tem como objetivo geral compreender a atuação dos multiplicadores no Instituto Batucar e, como objetivos específicos: descrever as práticas musicais desenvolvidas no Instituto Batucar; identificar as estratégias pedagógico-musicais dos multiplicadores e conhecer como os multiplicadores percebem sua atuação no projeto.

Para atingir os objetivos, foi realizado um estudo de caso com coleta de dados por meio de observações das práticas pedagógico-musicais e entrevistas semiestruturadas, individuais e coletivas, com os profissionais que atuam no IB (coordenadores e multiplicadores). Estas foram transcritas literalmente e analisadas por meio da interpretação das falas dos participantes.

\footnotetext{
${ }^{1}$ Disponível em: www.institutobatucar.com.br. Acesso em mar. 2013
} 
Esta pesquisa se insere no âmbito da Educação Musical não formal, especificamente na discussão sobre a Formação de Professores de Música para atuar em diferentes contextos. Nesse sentido, este estudo possibilitará conhecer e refletir, assim como criar subsídios para fomentar o debate sobre as práticas pedagógico-musicais em projetos sociais e sobre a atuação de educadores sociais, especialmente no Distrito Federal.

O primeiro capítulo constituiu-se desta introdução em que explico a origem e o interesse em pesquisar projetos sociais em que há o ensino da música. Apresento os objetivos, gerais e específicos, o lócus da pesquisa, o Instituto Batucar, e a metodologia utilizada.

No segundo capítulo apresento os conceitos de projeto social, ONGs e OSCIP, na concepção de Gohn (2010), Mckinsey \& Company Inc. (2001), Andrade (2002), Ferrarezi e Rezende (2001) e segundo a legislação brasileira, de 1999. O capítulo apresenta também o conceito de processo educativo na educação não formal e pesquisas realizadas sobre as práticas musicais em projetos com temáticas relacionadas a processos pedagógico-musicais e à formação do profissional de música.

Os processos pedagógico-musicais em projetos sociais trazem a perspectiva de Hikiji (2006) em que se reflete sobre a formação cidadã como um dos objetivos da educação musical. Essas práticas, ou processos, evidenciam a educação musical como fato social a partir das pesquisas de Kleber (2006), Torres (2008), Callegari (2008), Menezes (2009) e Medeiros (2009).

No terceiro capítulo, são abordados a educação não formal e o educador social, na concepção de Gohn (2010). Nesse capítulo, os conceitos de Gohn (2010) e Freire (2011) caracterizam o educador e a metodologia nos projetos sociais. Esse educador é entendido como aquele que intervém no mundo, um sujeito comprometido com os alunos (FREIRE, 2011). A educação não formal é definida por Gohn (2010) como aquela que acontece por meio do compartilhamento de experiências utilizando-se o diálogo como um fio condutor para a interação dos profissionais com os alunos. Para essa autora, a educação não formal é um conceito em construção e um processo em que se aprende a conviver nas vivências e nas interações entre educadores e alunos.

No quarto capítulo, apresento a metodologia desta investigação e a imersão no campo empírico: o Instituto Batucar. A metodologia de pesquisa adotada se fundamenta em uma abordagem qualitativa, do tipo estudo de caso em que a unidade de caso é a atuação dos multiplicadores, segundo André (2000) e Alves Mazzotti (2006). Como técnicas de investigação, utilizei entrevistas individuais (MONTANDON, 2008) e entrevista do tipo grupo focal com os multiplicadores (DIAS, 2002). Participei das atividades do Instituto 
Batucar como observadora participante (VALLADARES, 2007), quando planejei minhas visitas de acordo com os dias e horários disponibilizados pelo projeto (GIL, 2002). As entrevistas foram transcritas e analisadas, o que permitiu compreender a atuação dos multiplicadores por meio da fala dos próprios participantes da pesquisa (BOGDAN; BIKLEN, 1994; DUSILEK, 1986).

No quinto capítulo, apresento o local da pesquisa, o Instituto Batucar, sua origem, as atividades desenvolvidas, as parcerias do projeto, os princípios pedagógicos adotados pelo Instituto, os seus objetivos e a sua estrutura organizacional.

No sexto capítulo, apresento a atuação dos multiplicadores no Instituto Batucar como aprendizes e monitores, em que descrevo suas atividades: o ensino da música, a troca e o compartilhamento de saberes e práticas com os alunos. Sua atuação constitui a identidade do grupo. A interação entre os multiplicadores e os aprendizes reflete a natureza da música como um fato sociocultural e não há como separar a música da socialização, como aponta Souza (2004). A aprendizagem dos multiplicadores acontece também com o outro, ou seja, com o aluno, com outros multiplicadores e com a equipe do IB. Segundo Gohn (2010), para que esse aprendizado se desenvolva é necessária a adaptação do educador ao meio social e a construção de vínculos sociais com os aprendizes, o que facilita o aprendizado e o desenvolvimento dos alunos.

$\mathrm{Na}$ sua atuação, os multiplicadores trabalham valores humanos como o respeito e a amizade. Eles utilizam estratégias de ensino como o acompanhamento escolar e a roda de percussão corporal, enfatizando o prazer em aprender, característica essencial para o ensino e aprendizagem, como destaca Cortella (2002) e Morandi (2008). Sobre a formação de professores são citados os autores Azevedo (2007) e Garcia (2011), que enfatizam o saber da experiência vivenciado na prática de ensinar.

Nas considerações finais, respondo os objetivos gerais e específicos que nortearam a pesquisa realizada no Instituto Batucar, em que foi objeto de estudo a atuação dos multiplicadores. Apresento minhas conclusões no período em que foram realizadas as visitas no projeto, propondo algumas questões que podem ser pesquisadas futuramente. 


\title{
2 PROJETO SOCIAL E EDUCAÇÃO MUSICAL
}

Neste capítulo são apresentados o conceito de ONGs (Organizações Não Governamentais) no Brasil e pesquisas voltadas para a prática da música em projetos sociais. Essas pesquisas abordam temáticas relacionadas a processos pedagógico-musicais, à formação de educadores na educação não formal e aos significados atribuídos à música pelos participantes de projetos sociais.

\subsection{PROJETO SOCIAL, ONGs e OSCIPs: UM CONCEITO COMUNITÁRIO E SOLIDÁRIO}

Os projetos sociais estão inseridos no Terceiro Setor (ANDRADE, 2002; PEDROSO; ROCHA, 2010). O primeiro setor consiste no Estado, o segundo setor é o mercado e o terceiro setor surge com a necessidade de articular o público e o privado, ou seja, o primeiro e o segundo setor (PEDROSO; ROCHA, 2010, p. 03).

Segundo a Organização das Nações Unidas para a Educação, a Ciência e a Cultura, $\mathrm{UNESCO}^{2}$, o Brasil é reconhecido pelas desigualdades sociais e, para reverter esse quadro social, têm sido criados mecanismos como a participação social por meio de projetos sociais, que ostentam ações de transformações positivas. Sobre esse assunto a UNESCO afirma que,

\begin{abstract}
Apesar de possuir grande número de pessoas pobres, o Brasil não é um país pobre, mas tem que superar um quadro de injustiça social e desigualdade. As desigualdades sociais estão presentes em todo o país, o que se reflete em uma posição intermediária ocupada pelo Brasil no ranking de países do Índice de Desenvolvimento Humano (IDH). Isso significa que ainda há muitas dificuldades a serem superadas nas áreas de educação, assistência social, saúde, distribuição de renda e emprego (UNESCO, s/d, a).
\end{abstract}

Segundo a entidade mundial, a pobreza presente no país está relacionada às desigualdades sociais, à discriminação, à violência, à vulnerabilidade, à exclusão social e à distribuição de renda. Nesse cenário, os projetos sociais têm sido criados para reverter à desigualdade e elevar os índices do desenvolvimento humano. Na visão da UNESCO, as ações sociais mobilizadas pela sociedade, de forma direta ou indireta como projetos sociais, podem contribuir para "a promoção da cidadania" e "da igualdade" social (UNESCO, s/d, b). O mesmo é afirmado pelo $\mathrm{CENPEC}^{3} /$ Fundação Itaú Social $/ \mathrm{UNICEF}^{4}$ (2003, p. 35), ao

\footnotetext{
${ }^{2}$ UNESCO: United Nations, Educational, Scientific and Cultural Organization,

${ }^{3}$ Centro de Estudos e Pesquisas em Educação
} 
ressaltar que é preciso que os projetos construam alternativas de combate à exclusão social, portanto, é preciso que eles gerem uma transformação social, uma mudança, sob o ponto de vista das políticas públicas.

Os projetos sociais se estruturam e se efetivam por meio de ações intencionais promovidas por um grupo ou organização social, que são planejadas a partir do diagnóstico e da reflexão de uma situação problemática (STEPHANOU et al., 2003, p.01). Geralmente, nesses espaços são desenvolvidos processos de educação não formal, segundo a dinâmica de cada proposta, em que são oferecidas atividades ou oficinas educativas, culturais, de saúde, de formação cidadã e de lazer como: artesanato, esporte, música, dança, educação sexual e meio ambiente. Essas atividades podem variar conforme as demandas da comunidade, dos espaços e dos recursos disponíveis, dos profissionais e dos voluntários em atuação e da identidade das organizações ou grupos sociais.

O surgimento de projetos sociais é intensificado a partir dos anos 90, quando as ações sociais no Brasil aumentaram com o crescimento de projetos nas áreas de "educação, ciências naturais, ciências sociais, cultura, comunicação e informação" (UNESCO, s/d, c). Desde então, os projetos começaram a se articular com o governo e a sociedade civil.

No âmbito da sociedade civil, Gohn (2010, p. 75) relata que há, na atualidade, predominância de associativismo urbano tanto no Brasil quanto nos países latino-americanos, como a Argentina e o Chile. Esse associativismo impulsiona as organizações do terceiro setor que atuam via projetos sociais. O termo terceiro setor, na concepção de Ashoka Empreendimentos Sociais e McKinsey \& Company, Inc. (2001), é utilizado para "designar organizações da sociedade civil, sem fins lucrativos, criadas e mantidas com ênfase na participação voluntária que atuam na área social visando à solução de problemas” (p. 13). Elas podem ser estruturadas como Organizações Não Governamentais (ONGs), Organizações da Sociedade Civil de Interesse Público (OSCIPs), Fundações, Institutos e Associações.

As ONGs apareceram no Brasil nas décadas de 60 e 70, ligadas ao terceiro setor. (ANDRADE, 2002). O terceiro setor é apresentado por Gohn (2010) como uma organização social com diferentes possibilidades de agrupamento e caracterização. Em suas palavras:

O terceiro setor brasileiro é composto por inúmeras associações e entidades com perfis variados. Essas associações e entidades sobrevivem graças ao apoio financeiro e institucional que recebem de empresas, nacionais e internacionais, fundações também empresariais, bancos e outras entidades da sociedade civil. Este conjunto de entidades patrocina inúmeros projetos sociais, projetos formulados com premissas associativistas destinados a clientelas carentes, num universo multifacetado das

\footnotetext{
${ }^{4}$ UNICEF: United Nations Children's Fund
} 
experiências associativas, inscrevendo suas atuações no universo das políticas de responsabilidade social (GOHN, 2010, p. 76).

Dentro das políticas de responsabilidade social, as organizações no terceiro setor podem qualificar-se como OSCIPs. Uma instituição é assim denominada quando atende a pelo menos uma das finalidades propostas no artigo $3^{\circ}$ da Lei $n^{\circ} 9790$, de 23 de Março de 1999, que "dispõe sobre a qualificação de pessoas jurídicas de direito privado, sem fins lucrativos, como Organizações da Sociedade Civil de Interesse Público, institui e disciplina o Termo de Parceria, e dá outras providências" (BRASIL, 1999). O Art. $3^{\circ}$ contempla pessoas jurídicas de direito privado, sem fins lucrativos, que atendam a uma das seguintes finalidades: assistência social; promoção da cultura e preservação do patrimônio; promoção da educação, da saúde, da alimentação, da defesa e da preservação do meio ambiente visando a sustentabilidade; promoção de voluntariado, do desenvolvimento econômico e do combate à pobreza; experimentação de novos modelos sócio-produtivos de forma não lucrativa; construção de novos direitos e assessoria jurídica gratuita; promoção da ética, da cidadania, dos direitos e dos valores humanos (BRASIL, 1999).

Segundo Ferrarezi e Rezende (2001), a OSCIP tem por objetivo fortalecer o terceiro setor. Quanto a esses objetivos, os autores destacam a importância de qualificar esse tipo de oferta de serviço. Em suas palavras, é importante:

\footnotetext{
Qualificar as Organizações do Terceiro Setor por meio de critérios simples e transparentes, criando uma nova qualificação, qual seja, Organização da Sociedade Civil de Interesse Público/OSCIP.

i) Incentivar a parceria entre as OSCIPs e o Estado, por meio do Termo de Parceria, um novo instrumento jurídico criado para promover o fomento e a gestão das relações de parceria, permitindo a negociação de objetivos e metas e também o monitoramento e a avaliação dos resultados alcançados;

ii) Implementar mecanismos adequados de controle social e responsabilização das organizações com o objetivo de garantir que os recursos de origem estatal administrados pelas OSCIPs sejam, de fato, destinados a fins públicos (FERRAREZI; REZENDE, 2001, p. 20).
}

Dentre as atividades desenvolvidas pelas OSCIPs, no âmbito educacional, podem ser observados a oferta de acompanhamento pedagógico, aulas de informática, esportes, música, dança e teatro. Entretanto, essas atividades podem variar conforme as demandas e o interesse de cada comunidade.

Cortella (2002), ao discorrer sobre o trabalho no terceiro setor desenvolvido por ONGs ou OSCIPs, destaca o papel singular e relevante dessas instituições na formação de comunidade: 
[...] a ONG [e também as OSCIPs] não deve ser um local em que se aprende apenas de forma ocasional. Ela não pode abrir mão de passar adiante conteúdos fundamentais para o enfrentamento do mundo. E não se trata apenas de conteúdos científicos, mas também ligados à música, à estética, à religião, à sensibilidade (CORTELLA, 2002, p. 99-100).

Cortella (2002) alerta, portanto, a respeito da diversidade de temas ofertados pelo terceiro setor. Nele, o processo educativo é flexível e situado. Segundo Gohn (2010), a educação nesse setor é, predominantemente, não formal, ou seja, apresenta particularidades que a diferenciam da educação formal e informal, discussão que será aprofundada no capítulo 3. Contudo, cabe destacar o caráter formativo, social, dinâmico, heterogêneo, flexível e intencional que identifica a educação não formal. A educação não formal defendida por Gohn (2010) coloca em foco as práticas desenvolvidas nesses contextos, suas metodologias e seus agentes educacionais.

No Distrito Federal, por exemplo, os projetos sociais que adotam a prática musical, de modo geral, têm uma preocupação com as necessidades de formação sociocultural e de lazer de crianças e jovens de comunidades em situação de vulnerabilidade, ou seja, sujeitas à criminalidade, ao tráfico de drogas e à violência urbana. Nesse contexto, contudo, os coordenadores, supervisores e instrutores são profissionais familiarizados com a música, mas não são, necessariamente, educadores formados ou licenciados em música (ALMEIDA, 2005) ou preparados para trabalhar com o público denominado "de risco". O contato com os alunos, os desafios diários de interação e de ensino e aprendizagem, a falta de recursos e o dinamismo necessário em sala de aula fazem com que o profissional cresça e aprenda a ser educador social.

A realidade dos projetos sociais tem sido estudada e pesquisada por educadores musicais interessados nos processos pedagógico-musicais e no significado da música para essas comunidades. No tópico seguinte, são apresentadas algumas pesquisas sobre o ensino e a aprendizagem musical em projetos sociais em que a música é uma prática importante como atividade sociocultural. 


\title{
2.2 A MÚSICA EM PROJETOS SOCIAIS: AS PESQUISAS
}

$\mathrm{Na}$ atualidade, são muitos os espaços em que o educador musical pode atuar, dentre eles a educação não formal como afirma Penna, Barros e Mello (2012):

\begin{abstract}
Atualmente, são múltiplos os espaços de atuação para o educador musical, pela diversidade de contextos educativos, escolares ou extraescolares. Em espaços não formais - como organizações não governamentais (ONGs), projetos sociais, associações comunitárias - a música tem sido bastante valorizada em projetos voltados para a inserção social. Várias pesquisas têm analisado experiências que, através do desenvolvimento da prática musical, cumprem diversas funções de caráter social - como Kleber (2006), Hikiji (2006) ou Cançado (2006). (PENNA; BARROS; MELLO, 2012, p. 66).
\end{abstract}

A música nesses locais apontados por Penna, Barros e Mello (2012) é valorizada e é de caráter social. O aumento de ofertas de atividades musicais em projetos sociais, segundo Hikiji (2006), tem delimitado uma cultura de ensino e aprendizagem musical em que o ensino da música não é ministrado de forma técnica, visando formar um grande virtuoso no instrumento ou um profissional da música, mas é voltado para mudança de vida, ou seja, transformar a vida de jovens e adolescentes que não têm outra opção educativa, cultural ou ocupacional.

As oficinas, as aulas, os ensaios e as apresentações são atividades criadas, desenvolvidas e compartilhadas no contexto dos projetos sociais com características de educação não formal para a transformação social. Nesses espaços, o jovem tem liberdade para exercer sua cidadania como sujeito social em constante formação. Segundo Arroyo (2013), as práticas musicais são fundamentais na constituição das identidades juvenis e adulta. Ela afirma que "as práticas musicais participam ativamente das constituições juvenis ao mesmo tempo em que novas estéticas musicais são criadas a partir das ações dos jovens" (ARROYO, 2013, p. 14). Portanto, os projetos sociais têm se constituído em espaços singulares de valorização e de formação pessoal e social de crianças e jovens. Destacam-se nesse contexto o projeto Guri, os Meninos do Morumbi, em São Paulo, e o projeto Villa-Lobinhos no Rio, dentre outras experiências espalhadas pelo país.

O projeto Guri investigado por Hikiji (2006) desenvolve, principalmente, a formação musical por meio de prática orquestral e coral, quando o aluno tem contato tanto com o repertório erudito quanto com o popular. As aulas de instrumentos são em grupos, com ensaios para apresentações externas. O aluno tem duas aulas por semana, de coral ou de instrumentos, com duração de uma a duas horas/aula. As turmas variam entre dois e vinte 
alunos. O projeto separa os alunos por nível iniciante e avançado. $\mathrm{O}$ ensino de teoria musical ocorre durante as aulas de instrumento ou em aulas específicas com o maestro. A proposta educativa do Guri é formar instrumentistas em cerca de um mês no projeto, para atuarem nas orquestras.

Em seu estudo, Hikiji (2006) percebeu diferentes concepções entre o olhar da coordenação técnica e o olhar dos músicos que ministram as aulas. Numa das entrevistas realizadas, a coordenadora relatou que o Guri transforma a vida das pessoas. Isto porque ele se localiza onde as pessoas não têm acesso a aulas de instrumentos e nem podem adquirir seu próprio instrumento. Dessa forma, as crianças e os jovens entram no Guri para ter acesso a aulas de música e a um instrumento, participando de apresentações artísticas. As famílias dos participantes acompanham toda a trajetória dos filhos inseridos no projeto Guri. Esse momento é uma situação nova na vida dessas pessoas, pois elas talvez nunca tenham vivenciado um momento como esse em suas vidas, um momento em que o filho passa a ter aulas de música, ganha um instrumento para treinar e estudar e ainda participar de apresentações artísticas. O momento de apresentação é um momento de apreciação das famílias, uma forma de incentivo e gratidão dos alunos, tanto para com os pais como para com os educadores que estão presentes, um momento de realização pessoal para todos, alunos, professores e pais.

No Guri, os alunos aprendem música erudita, que, para a coordenadora do projeto, se torna popular pelo fato do próprio estilo chegar às classes de baixa renda, quando o acesso à música clássica é socializado e democratizado. Outro ponto destacado pela coordenadora do Guri é o desenvolvimento de habilidades extramusicais como a concentração e a responsabilidade dos alunos (HIKIJI, 2006, p.105).

O Guri é percebido como um projeto facilitador e disseminador do acesso a música. Em um dos polos do projeto Guri começaram aulas de instrumentos mais familiares ao público - músicas que utilizam instrumentos como o cavaquinho, o violão, a percussão. Depois, foram introduzidos instrumentos mais clássicos como o trombone, trompete, clarinete e outros (HIKIJI, 2006, p. 106). Há um entendimento de que há um estranhamento da música clássica não somente pela população pobre, mas também por todo brasileiro em geral (HIKIJI, 2006, p. 107).

Segundo a Presidente da Sociedade dos Amigos do Projeto Guri, o objetivo do projeto não é só exercer uma atividade musical, mas também formar músicos e ouvintes qualificados. Hikiji (2006) destaca que para o maestro da orquestra do polo Mazzaropi, todos os professores de música do Guri são profissionais (músicos) e, para eles, o maior prêmio será 
formar todos os alunos, para que também possam se tornar profissionais ou, se não, pelo menos que saiam do Guri sabendo ouvir música. Quanto ao objetivo do projeto, Hikiji (2006) acrescenta que "não é formar músicos, mas sim trabalhar autoestima, cidadania, tirar a criança da rua e mostrar para ela uma condição de vida melhor" (HIKIJI, 2006, p. 76).

A autora mostra que o estudo da música dentro do projeto é um meio de mostrar aos alunos que eles podem mudar e viver uma outra realidade por meio do estudo da música. Eles podem ter aulas e ensaios de música com repertórios eruditos e populares e podem estudar em casa ao invés de estar na rua expostos à criminalidade e ao tráfico de drogas. Podem, a partir da vivência no projeto Guri, ter outros objetivos de vida futura como ter um emprego, estudar e se profissionalizar, não necessariamente na música, mas também em outras áreas.

Outro ponto importante na valorização pessoal e social no Guri são as apresentações artísticas que os alunos realizam. Hikiji (2006) comenta sobre a "magia do palco" na identidade e na vida cotidiana dos participantes do projeto:

\begin{abstract}
A magia do palco é incorporada (uma vez que a música age nas vísceras) e carregada para a vida cotidiana dos jovens. As imagens de si construídas no jogo com a plateia, com o apresentador (e com a identidade que sua fala lhes atribui) farão parte das noções de pessoa ainda em construção. É inevitável, após uma apresentação, que se sintam importantes. Muitos passarão a ser respeitados pela família, que assistiu na TV (HIKIJI, 2006, p. 166-167).
\end{abstract}

A admiração e o respeito da família são importantes, assim como o reconhecimento do trabalho e da dedicação ao estudo musical na vida dos estudantes, pois eles se sentem valorizados pela plateia. Na pesquisa realizada por Hikiji (2006), verifica-se que os projetos sociais investem no resgate da autoestima, fazendo com que o jovem se sinta admirado pelos outros colegas, não porque possui uma arma, o que é normal na cidade em que vive, mas porque sabe tocar um instrumento, porque estuda música.

A autora ainda compara a prática social em projetos sociais de música aos programas esportivos oferecidos às comunidades de vulnerabilidade social nos anos de 1980. Nessa época, segundo a autora, o esporte tinha uma perspectiva "unificadora, higienista e cívica", [...] "o que coincidira com o programa musical de Villa-Lobos, se considerar as análises de Wisnik e Contier" (HIKIJI, 2006, p. 80). Programas como o "Priesps ${ }^{5}$, da Fundação Roberto Marinho, enfatizavam não a disciplina, mas a sociabilidade e o lúdico” (HIKIJI, 2006, p. 81).

Hikiji (2006) enfatiza que novas perspectivas formativas estão relacionadas aos objetivos e valores dos projetos sociais atualmente, que podem fazer surgir "novas pautas

\footnotetext{
${ }^{5}$ Priesps - Programa esportivo da Fundação Roberto Marinho. Citado por Hikiji, 2006.
} 
como cidadania, auto-estima e inclusão social" (HIKIJI, 2006, p. 81). Segundo a autora, os projetos sociais são voltados para a "[...] infância e adolescência em situação de risco" (HIKIJI, 2006, p. 82) e visam a sua transformação e não uma perspectiva ideológica e cívica. O significado do termo "situação de risco" na visão de Hikiji remete ao sentido de "perigo ou possibilidade de perigo", ou seja, ao usar essa expressão, a autora está falando do "perigo de ser criança e jovem, sobretudo de baixa renda, no Brasil" (HIKIJI, 2006, p. 82). Ela afirma que a concepção de rua vigente antigamente era de um espaço para brincadeiras, para reunir os amigos, para fazer amizades, mas agora, ela está associada ao perigo, ao lugar perigoso onde a criança e o jovem estão expostos ao mundo do crime, da marginalidade.

O Estatuto da Criança e do Adolescente (ECA), Lei federal $n^{0} 6.697$, de 10 de outubro de 1979, prevê a "proteção integral à criança e ao adolescente, independentemente de sua condição social". Para o ECA, crianças e adolescentes são "caracterizados como sujeitos de direito" (HIKIJI, 2006, p. 83) e a "situação de risco" é um conjunto de fatores que impedem o exercício dos direitos das crianças, como o direito à vida, ao lazer, ao respeito e à liberdade.

$\mathrm{O}$ ensino e a aprendizagem musical em projetos sociais têm garantido o exercício desses direitos, principalmente quando resgatam a autoestima e possibilitam alternativas de profissionalização e de inclusão social. A prática musical nesses contextos tem também merecido a atenção de outros pesquisadores da educação musical. Dentre os trabalhos se destacam as pesquisas de Almeida (2005), Kleber (2006a), Torres (2008), Callegari (2008), Menezes (2009) e Medeiros (2009).

Os projetos sociais Villa Lobinhos (RJ) e Associação Meninos do Morumbi (SP) foram pesquisados por Kleber (2006a). A autora considerou, na análise da sua pesquisa, quatro dimensões: institucional, histórico, sociocultural, de ensino e aprendizagem musical e aspectos pedagógico-musicais.

$\mathrm{Na}$ dimensão institucional a autora afirma que são consideradas nos projetos questões de natureza "burocrática, jurídica, disciplinar, morfológica" (KLEBER, 2011b, p. 39). A dimensão histórica considera o processo da história dos projetos construída a partir das falas dos participantes de sua pesquisa. A dimensão sociocultural considera os encontros, as interações dos participantes dos projetos. Na dimensão de ensino e aprendizagem musical, a autora foca "como, onde, por que, para que se aprende e se ensina música no contexto pesquisado" (KLEBER, 2011b, p. 40).

Em sua pesquisa Kleber fundamenta-se em Mauss (apud KLEBER, 2011b) ao considerar as práticas musicais nas ONGs como fato social total, ou seja, compreendê-las 
como um conjunto de fatores complexos que envolvem "os aspectos físicos, institucional e simbólico" das ações (p. 39). A partir de Mauss, Kleber (2006c) afirma que "o processo pedagógico-musical nas ONGs pode ser pensado como um fenômeno social envolvendo essas diferentes dimensões e contextos e, portanto, um fato social total, não se reduzindo a um processo de ensino e aprendizagem musical, ainda que este considerado na sua multiplicidade" (p.36).

Souza (2004) afirma que a música não pode ser descontextualizada da questão sociocultural, ou seja, não há como separar a música do fator social. A prática musical faz parte da cultura dos estudantes.

Situações pontuadas nas práticas musicais como convivência e interação, domínio de aula com gestão e desenvolvimento de habilidades para resolver diversas situações, estratégias mais criativas relacionadas ao ensino da música e a diversidade de demanda para o professor, são aspectos que precisam ser levados em conta para se aprender a ser professor nesse contexto. Ao considerar o fato social total em ONGs, Kleber (2006c) afirma que "é preciso que ele seja considerado também sob o ponto de vista da experiência individual em que se possa observar o comportamento de seres totais, e não divididos em faculdades" (p. $35)$.

Outra perspectiva que a autora destaca em relação à produção de conhecimentos musicais inseridos nas ONGs são suas análises a partir da teoria da práxis cognitiva, com fundamentação em Eyerman e Jamison (apud KLEBER, 2006a). Nessa perspectiva teórica, é analisada a produção sociomusical das ONGs. As dinâmicas do social e do conviver nesses espaços abrem novas possibilidades para produzir novas formas de conhecimento.

O Projeto Villa-Lobinhos (RJ), pesquisado por Kleber (2011b), atende crianças de 12 a 20 anos (p. 38). As turmas são organizadas com 27 alunos, 09 em cada turma. A proposta pedagógico-musical acentua-se na formação de instrumentistas, contudo a prática musical coletiva é valorizada, como afirma Kleber: "com aulas individuais, os processos coletivos ligados à prática musical prevalecem sobre os processos individuais" (KLEBER, 2006c, p. 109).

No projeto Associação dos Meninos do Morumbi (SP), são atendidos 3.500 crianças e adolescentes e a missão da ONG é promover a aprendizagem por meio da arte, ampliar a inclusão (KLEBER, 2006c, p. 179). A autora considera que o lúdico pode ser percebido no processo pedagógico-musical, pois os jovens expressam o prazer por estarem nesses espaços. A autora também considera que: 
[...] as performances dos grupos musicais das duas organizações selecionadas são entendidas aqui como fruto do processo pedagógico-musical. Constituem o repertório que eles tocam e gostam de tocar, construídos ao longo do trabalho realizado nos diferentes espaços como sala de aula, ensaios, apresentações, jogos musicais (KLEBER, 2006d, p. 135).

Nos diferentes espaços, entre aulas, ensaios e jogos musicais, são desenvolvidos os conhecimentos e as práticas musicais em sua dimensão sociocultural, em que estão presentes o coletivo e a interação entre os indivíduos. A pesquisa de Kleber contribui de forma significativa para a reflexão de práticas de ensino e aprendizagem musical nos movimentos e projetos sociais, locais onde se busca também a transformação social de alunos.

Em outro estudo, Kleber (2011b) aborda o significado de "redes de sociabilidade" a partir do Projeto Villa-Lobinhos, com a Escola de Música da Rocinha (EMR) e a Orquestra Grota do Surucucu, em Niterói. A pesquisadora analisa a dinâmica da rede de sociabilidade entre o Projeto Villa-Lobinhos e as outras organizações, a partir de uma visão sistêmica fundamentada.

Para sustentar o argumento de que as práticas musicais são fruto da experiência vivida de forma concreta, em múltiplos contextos, Shepherd e Wicke (apud Kleber, 2011b) se fundamentam no conceito de estrutura social, que defende a música como uma prática constituída social e culturalmente, segundo o conceito de fato social total de Marcel Mauss e a teoria sobre a produção do conhecimento sociomusical de Eyerman e Jamison (apud Kleber, 2011b).

Kleber (2011b) complementa suas ideias com o pensamento de John Blacking e Small (apud KLEBER, 2006a). A performance, segundo Blacking, é "um evento padronizado na interação do sistema social, cujo significado não pode ser entendido ou analisado isoladamente de outros eventos no sistema" (BLACKING apud KLEBER, 2011b, p. 39). De forma semelhante, para Small, a performance está associada ao "fazer musical" e ao "senso de musicalidade" das pessoas como resultados da interação interpessoal (SMALL apud KLEBER, 2011, p. 39).

Mas o que é então essa "rede de sociabilidade?" Para a autora, as conexões entre o Projeto Villa-Lobinhos e as demais ONGs apresentou-se multidirecional, com diversos elos ligados pelas esferas cultural, artística, institucional e pessoal no Rio de Janeiro. A atuação forte das ONGs no Rio de Janeiro transformou o lugar em um laboratório social que inspirou outros projetos no país conforme também afirma Novais (apud KLEBER, 2011b).

Kleber (2011b) considera que os valores e os objetivos caracterizam a identidade da rede. Ela relata que a rede entre o Projeto Villa-Lobinhos e o projeto localizado na favela 
Grota do Surucucu, coordenado pelo Instituto Reciclarte, otimizou as propostas musicais de ambos os projetos sociais. Os alunos da Grota aprenderam muito com os alunos do Projeto Villa-Lobinhos e vice-versa, pois houve uma troca de experiências musicais.

O fator pedagógico-musical foi interpretado e enfatizado por Kleber (2011) como um fato social, pois valores simbólicos e materiais foram ligados às práticas musicais. As redes de sociabilidade musical são mobilizadas pelas motivações internas e coletivas através de um convívio sócio-musical. Os resultados de sua pesquisa revelam que a performance musical é um condutor dos processos de ensino e aprendizagem e as práticas educativas, o lazer e o cuidado com o instrumento são partes do contexto do processo pedagógico-musical (p. 46).

O saber nas ONGs pode articular novos interesses e visões de mundo. As pessoas estão em constante movimento, seja por meio de lugares, onde podem conhecer outras pessoas de culturas diferentes, seja em sua própria comunidade, criando novas ideias juntamente com pessoas de sua mesma cultura. Essas ideias podem gerar outras formas e outros propósitos, ou seja, podem gerar outras formas de fazer música. As pessoas podem até mesmo criar a sua própria música, da sua maneira, do seu jeito a partir de uma técnica aprendida, compreendida e estudada.

Essa maneira de fazer música é observada também no processo pedagógico-musical investigado pela Medeiros (2009) que, ao analisar as aulas de música em um presídio, utilizou como principais referências Kleber e Mauss (MEDEIROS, 2009). Medeiros teve como objetivo geral de sua pesquisa a relação dos presidiários com o processo pedagógico-musical, seu cotidiano e compreensão da cultura local.

A autora considera o presídio um local pouco explorado por pesquisadores, sendo um ambiente que pode contribuir com o campo da educação musical. O estudo trata de um fenômeno social complexo em que a música pode ser analisada como fato social.

Ao realizar uma pesquisa na ONG Corpo Cidadão, em Belo Horizonte, Minas Gerais, Menezes (2009) investigou o processo pedagógico-musical na Organização. Para o autor, as práticas musicais acontecem de forma coletiva e interativa e têm como condução do ensino e da aprendizagem musical a performance de crianças e adolescentes que vivem em situação de risco e vulnerabilidade social.

Com temática distinta dos trabalhos anteriores, Callegari (2008) investiga a relação indivíduo-música no projeto Cantadores do Vento da ONG EMCANTAR. Ela analisou os significados intersônicos e delineados atribuídos pelos participantes de um projeto social à música a partir da proposta teórica de Lucy Green. Os resultados revelam que os significados musicais estão presentes nas atividades do projeto, desde o ensaio à performance 
desenvolvida pelos participantes. Esses significados podem ser observados na cena "ensaio só da música", e na música "Beira Mar", observados pela pesquisadora. Os resultados revelam que há evidências de que os significados atribuídos à música estão associados com as relações apresentadas na cena.

Sobre a atuação de educadores inseridos nos projetos sociais, Almeida (2005) pesquisou as práticas de oficineiros em projetos sociais, identificou os profissionais atuantes nas oficinas de música e analisou as concepções desses profissionais em relação à educação musical nos projetos. Para a pesquisa foram considerados os espaços de educação não formal onde se ensina e aprende música no projeto Descentralização, projeto da Secretaria Municipal de Cultura, da Prefeitura de Porto Alegre.

O principal objetivo da autora foi caracterizar o ensino da música no projeto Descentralização. Nele foram analisadas as dimensões pedagógicas presentes nas práticas do ensino da música e nas oficinas. A partir desse objetivo, Almeida (2005) identificou a atuação e a formação dos profissionais atuantes no projeto. A pesquisa se fundamentou nos teóricos da educação não formal, autores da pedagogia e da educação musical.

A autora realizou um Survey em 19 oficinas de música e analisou as experiências dos oficineiros a partir de entrevistas. Dentre seus resultados, Almeida (2005) destaca que tais profissionais são selecionados a partir dos currículos e não é exigido conhecimento pedagógico na área em que irão atuar, ou seja, o conhecimento prático já é suficiente. Segundo a autora, os oficineiros apesar de possuírem, em sua maioria, formação prática como autodidatas, possuem uma visão de educação musical mais tradicional associada a aulas particulares e individuais. Os profissionais entrevistados por Almeida (2005), apesar de trabalharem com aula em grupo, procuram realizar atendimento individual aos alunos, para priorizar a técnica. Ela cita ainda as dificuldades e a falta de recursos como carência de instrumentos musicais para dar aulas de música. Quanto à formação dos profissionais que atuam nos projetos, Almeida (2005) afirma que, nesses espaços, ainda são muito poucos os licenciados em música. Dos 14 oficineiros entrevistados pela pesquisadora, apenas um concluiu a Licenciatura em Música. Os resultados revelam ainda que os locais onde acontece a educação não formal ainda são pouco reconhecidos como espaços de atuação profissional de graduados licenciados.

A autora considera que sua pesquisa contribui para ampliar as discussões acerca da educação musical não formal e suas relações com a formação de professores de música em cursos de licenciatura, podendo também contribuir para o reconhecimento da educação não formal como espaço para a atuação de licenciados da educação musical dos cursos de música. 
As pesquisas demonstram que o terceiro setor tem se mostrado como um espaço propício e relevante para o ensino e aprendizagem musical. Nele se observam deferentes tipos de práticas musicais em que as pesquisas apontam o fazer musical como um fato social total e onde são desenvolvidos saberes e valores musicais, de sociabilidade, de interação e de autoestima. 


\section{EDUCAÇÃO NÃO FORMAL E O EDUCADOR SOCIAL}

Neste capítulo são discutidos os conceitos de educação não formal e educador social a partir de Freire (2011) e Gohn (2010). O conceito de educador social, na concepção de Gohn, está associado à atuação do profissional na educação não formal. Gohn (2010) caracteriza a educação não formal e os educadores que atuam nesses espaços como aprendizes no cotidiano, como sujeitos críticos que sabem construir o ensino e a aprendizagem a partir da prática de seus conhecimentos junto com os alunos.

O capítulo está dividido em duas partes: 1) educação não formal - um conceito em construção, em que é apresentado o conceito de educação não formal utilizado nesta pesquisa e as características dessa modalidade educativa; 2) educador social e o educador musical, em que é discutido o conceito de educador social, suas características, atitudes e saberes.

\subsection{EDUCAÇÃO NÃO FORMAL - UM CONCEITO EM CONSTRUÇÃO}

Gohn (2010, p. 16), ao definir e delimitar o conceito de educação não formal, destaca a necessidade de defini-la a partir de suas características particulares e não a partir de definições que a diferenciam ou a comparam com a educação formal e informal, ou seja, a autora critica a definição a partir do que ela não é. Nessa perspectiva, a educação não formal ainda é um conceito em construção, mas que vem sendo consolidado nas práticas não formais, especialmente, em projetos sociais. Esse processo não acontece naturalmente, pois há uma intenção na própria educação não formal, como afirma Gohn (2010).

Ao caracterizar a educação não formal, Gohn (2010, p. 44-45) lista algumas características e apresenta seus objetivos e metas: o aprender a conviver com as pessoas e sua diversidade, assim como socializar, respeitando uns aos outros; a adaptação a diferentes culturas presentes no grupo; o construir uma identidade coletiva do grupo; a unificação de regras relativas às condutas sociais de um grupo (GOHN, 2010, p. 44).

A primeira característica apontada por Gohn (2010), o aprender a conviver, é base para a consolidação das demais características, pois consiste nas vivências e no relacionamento entre aluno e professor, ou seja, entre o educador social e o aprendiz. Esse convívio social constitui uma construção de uma realidade na qual todos se adaptam e constroem sua própria identidade no grupo, onde são trabalhados os valores humanos como o respeito e a amizade por meio das aulas, dos jogos pedagógicos e das brincadeiras. 
Assim, a autora considera a educação não formal um processo em construção e intencional. Segundo Gohn (2010), a intencionalidade no processo de ensino está atrelada à atuação do educador que determina metas e constrói objetivos que são decisivos na seleção, organização e administração dos conteúdos e do currículo. Tais metas e objetivos representam o que o grupo acha que é mais importante para o aprendizado do aluno. Em suas palavras

Contrariamente, a educação não formal não é nativa, ela é construída por escolhas ou sob certas condicionalidades, há intencionalidades no seu desenvolvimento, o aprendizado não é espontâneo, não é dado por características da natureza, não é algo naturalizado (GOHN, 2010. p. 16).

A construção do processo educativo envolve as metodologias desenvolvidas a partir da cultura dos grupos de indivíduos. O processo educativo nasce a partir de um problema do cotidiano e os conteúdos aparecem a partir de temas vividos no dia a dia, como necessidades e carências dos grupos. Portanto, os conteúdos não são estabelecidos, mas são construídos durante o processo (GOHN, 2010, p. 47).

Nesse sentido, o educador social não precisa ter, necessariamente, uma formação para educar na educação não formal, mas Gohn (2010) aponta a falta de uma "formação específica dos educadores" bem como a falta de definições das funções e dos objetivos na educação não formal e a ausência de metodologias sistematizadas.

O processo educativo é construído, portanto, com uma maior liberdade e flexibilidade quando o assunto é metodologia nas aulas. Sobre esse assunto, Gohn (2010) considera que a metodologia "é um dos pontos mais polêmicos na educação não formal". Por ela ser flexível, nas palavras da pesquisadora, "muitos autores dizem que ela não tem métodos ou metodologias" (GOHN, 2010, p. 46). Para ela e outros autores, a presença de método descaracteriza o processo educativo não formal. Gohn concorda com Trilla ao afirmar que "a educação não formal não é um método ou uma metodologia”, mas sua sistematização “depende do processo em curso" (TRILLA apud GOHN, 2010, p. 46). A autora destaca que se a aprendizagem tem como sujeito alvo o meio ambiente ou a aprendizagem de instrumentos musicais ou outras aprendizagens geradas nos espaços educativos, as metodologias são diferenciadas (GOHN, 2010, p. 46).

A intencionalidade na educação não formal não é o diferencial entre a educação formal e a educação não formal, pois, segundo Gohn, ela existe nas duas modalidades educativas e é ela que "demarca um objetivo específico na educação não formal - formar para a cidadania" (GOHN, 2010, p. 34). 
Por outro lado, Gadotti (2005) defende que na educação não formal são muitos os espaços educativos, podendo esta ocorrer em igrejas e associações situadas em bairros. $\mathrm{O}$ autor enfatiza que o tempo é tão importante quanto o espaço na delimitação do conceito. $\mathrm{O}$ tempo de aprendizagem do indivíduo é flexível e essa flexibilidade é uma das características dessa modalidade educativa em que se respeita o tempo e as capacidades dos educandos.

Portanto, Gohn (2010) reforça a necessidade da educação não formal ser definida pelo que ela é, não pelo que ela não é. Ela deve ser reconhecida como um espaço onde ocorrem as aprendizagens que envolvem o plano social e emocional das pessoas e suas habilidades para a cidadania, como afirma a autora:

[...] um espaço concreto de formação com a aprendizagem de saberes para a vida em coletivos, para a cidadania. Esta formação envolve aprendizagens tanto de ordem subjetiva - relativa ao plano emocional e cognitivo das pessoas -, como aprendizagem de habilidades corporais, técnicas, manuais etc. que capacitam para o desenvolvimento de uma atividade de criação, resultando um produto como fruto do trabalho realizado. (GOHN, 2010, p. 40).

A autora defende a ideia de que o campo da educação não formal seja complementar à educação formal, não para fazer o que a "escola deveria fazer" (GOHN, 2010, p. 40), mas para complementar os campos de aprendizagem e saberes e atuar juntamente com a escola.

\subsection{EDUCADOR SOCIAL E O EDUCADOR MUSICAL}

Em alguns espaços, como as ONGs, onde se desenvolvem atividades esportivas, artísticas e de outra natureza, o profissional é muitas vezes denominado "educador social", pois atua com ações que promovem a cidadania e a transformação social de crianças e adolescentes em situação de risco e de vulnerabilidade social.

Nesse contexto, em que predomina a educação não formal, segundo Gohn (2010), o educador não deixa de ser um educador social. A autora destaca que o educador é o "outro", aquele com quem os aprendizes interagem e se integram, pode ser um instrutor ou o colega. Gohn (2010) afirma que ele ajuda na construção do próprio trabalho no local de trabalho. As forças sociais são construídas no processo por meio das relações compartilhadas entre os indivíduos.

Sobre o papel do educador na educação não formal, Gohn (2010), afirma que 
apoios ou qualquer outra denominação que se dê para os indivíduos que trabalham com grupos organizados ou não. Eles são fundamentais na marcação de referenciais no ato de aprendizagem, eles carregam visões de mundo, projetos societários, ideologias, propostas, conhecimentos acumulados etc. Eles se confrontarão com os outros participantes do processo educativo, estabelecerão diálogos, conflitos, ações solidárias etc. Eles se destacam no conjunto e por meio deles podemos conhecer o projeto socioeducativo do grupo, a visão de mundo que estão construindo, os valores defendidos e os que são rejeitados (GOHN, 2010, p. 47-48).

O educador social, segundo a autora, é importante no processo da educação não formal, pois traz uma bagagem de vivências e concepções, de conhecimentos adquiridos que é compartilhada com o grupo de indivíduos aprendizes. Isso acontece na sala de aula: uma troca de saberes, um compartilhamento de experiências por parte do educador social. Ele é mais que um "animador cultural" (GOHN, 2010, p. 50), pois exerce um papel de interação entre os indivíduos do grupo e desafia os participantes. Além disso, o educador social é dinâmico e desenvolve a construção de um processo participativo entre os integrantes do grupo. É aquele que dialoga, e isso, segundo a autora, não é somente um bate-papo entre aluno e professor, mas um fio condutor da formação dos indivíduos no processo.

Nesse sentido, o dinamismo no diálogo proporciona momentos em que o convívio do educador com o aluno se torna agradável, criando um ambiente de respeito entre ambos e momentos de aprendizagem e de convivência.

O educador nesse contexto é caracterizado, segundo Gohn (2010), como um aprendiz, e sua aprendizagem acontece via mão-dupla, ou seja, o educador aprende ao mesmo tempo que ensina e o diálogo é o seu meio de comunicação. O educador atua numa proposta socioeducativa em que há produção de saberes a partir da própria cultura dos indivíduos, que podem reconstruir e ressignificar valores existentes na cultura local.

Gadotti esclarece que o educador atuante na educação não formal é mais que um mediador dos conhecimentos. Ele é um organizador do conhecimento e da aprendizagem, um aprendiz permanente. Em suas palavras, ele "é aquele que cuida da aprendizagem" Gadotti, (2005, p. 03). O autor destaca que a aprendizagem do aluno depende de saber organizar o seu conhecimento, saber ser autodisciplinado e se sentir motivado.

Na concepção de Freire (1987), o profissional que ensina não é somente o educador, mas torna-se também um educando, ao aprender com os próprios alunos. Ele é educado enquanto educa, enquanto dialoga com seus alunos. Todos são parte no mesmo processo de ensino e aprendizagem. Freire (2011) ainda discute o papel do educador para a transformação social, a sua prática docente, suas atitudes e responsabilidades diante do processo de ensino e aprendizagem, suas vivências com os alunos envolvendo toda a prática educativa, ou seja, o 
pedagogo apresenta um novo olhar para o professor, como ser humano, como aquele que não só aprende, mas também ensina. Entende-se, assim, que a prática educativa envolve o contato com o ser humano de uma forma simples, mas responsável, em que professor e aluno são sujeitos que aprendem e ensinam.

Freire (2011) defende o aluno como sujeito "da produção do saber” (p. 24). Nesse caso, o ensinar não é apenas transferir conhecimento, mas um momento em que o docente cria possibilidades para construir e produzir conhecimento. Esses momentos tornam-se aprendizado tanto para os alunos como para os professores e contribuem para a construção de novos saberes, novas escolhas e temas geradores (FREIRE, 1987). É no diálogo, segundo Freire (1987), que acontece o aprendizado entre professor e aluno e entre aluno e professor. Nos momentos em que estão juntos, educadores e alunos, numa roda de conversa, acontece o processo educativo e todos tornam-se educadores e aprendizes. São momentos importantes que têm o seu valor pedagógico, de forma a contribuir para o crescimento dos sujeitos no processo de ensino-aprendizagem.

Ser professor é, pois, ser uma intervenção no mundo, é saber estar consciente da sua capacitação profissional. Para ensinar, Freire (2011) afirma que é necessário que o professor seja seguro, competente, generoso e comprometido, sempre respeitando os seus alunos. Freire (2011) aponta algumas características necessárias ao professor para ensinar, dentre elas destacam-se: (1) rigorosidade metódica; (2) sempre reforçar a capacidade crítica do aluno; (3) pesquisar, sempre buscar fontes de informações enquanto ensina; (4) respeitar os saberes dos educandos, inclusive os saberes construídos socialmente na educação não formal, aproveitando as experiências que os alunos trazem consigo; (5) criticidade e curiosidade; (6) estética e ética; (7) a corporificação das palavras pelo exemplo; (8) ensinar os alunos a pensar certo; (9) predisposição a correr riscos, aceitação do novo e rejeição a qualquer forma de discriminação; (10) reflexão sobre a prática; (11) reconhecimento e assunção da identidade cultural; (12) consciência do inacabamento e do condicionamento do processo educativo; (13) respeito à autonomia do ser do educando, bom-senso; (14) humildade, tolerância e luta em defesa dos direitos dos educadores; (15) apreensão da realidade; (16) alegria e esperança, convicção de que a mudança é possível. Enfim, ensinar exige curiosidade, disposição e comunicação.

Dessa forma, Freire (2011) destaca as responsabilidades do professor e aponta tipos distintos de professores que, segundo o autor, marcam de certa forma alunos que por eles passaram no processo educativo: 
O professor autoritário, o professor licencioso, o professor competente, sério, o professor incompetente, irresponsável, o professor amoroso da vida e das gentes, o professor mal-amado, sempre com raiva do mundo e das pessoas, frio, burocrático, racionalista, nenhum desses passa pelos alunos sem deixar a sua marca (FREIRE, 2011, p. 64).

Nesse sentido, o profissional é responsável por suas atitudes e modos de ser. Assim, suas qualidades e defeitos, suas maneiras de se relacionar com os seus alunos e com as situações ao seu redor, deixam um pouco de si na vida de quem passa por ele, ou seja, o aluno. O professor é lembrado por seus alunos das mais variadas formas: ele pode ser aquele que se transforma a cada dia ao ver as dificuldades e desafios, por falta de recursos, por exemplo, e responde de forma criativa às diversidades da prática docente ou pode ser aquele que se torna passivo e não se mobiliza para tentar amenizar as situações encontradas. O perfil de educador defendido por Freire deve ser criativo, dinâmico, e disposto a encontrar possibilidades para ensinar de forma lúdica e prazerosa, levando os alunos a mostrar mais interesse nas aulas. Nas palavras de Freire, sua aula é motivadora:

\footnotetext{
Sua aula é assim um desafio e não uma "cantiga de ninar". Seus alunos não cansam, não dormem. Cansam porque acompanham as idas e vindas de seu pensamento, surpreendem suas pausas, suas dúvidas, suas incertezas (FREIRE, 2011, p. 83-84).
}

Sua aula é aquela em que os alunos têm interesse. É uma aula produtiva e os alunos têm a oportunidade de desenvolver suas habilidades, construir novos conhecimentos, acompanhar as ideias do professor e assimilar os saberes que são mediados por ele. A aula, segundo Freire (2011), não deixa de ser um desafio. Ela é repleta de desafios, com os quais alunos e professores se deparam constantemente.

Para Freire (2011), educar exige respeito aos saberes dos educandos, pois eles são "socialmente construídos na prática comunitária" (FREIRE, 2011, p. 31). Ele defende a importância de discutir com os alunos a sua própria realidade, para refletir sobre o presente vivido por eles. $\mathrm{O}$ educador, portanto, em qualquer contexto educativo, deve agir como um professor curioso. O professor curioso é aquele que busca informações para formar-se e formar os seus alunos. Segundo o autor, sem a curiosidade no processo de ensino e aprendizagem, o professor nem aprende e nem ensina. O professor curioso é também aprendiz, aquele que dialoga com seus alunos e vê o diálogo como algo importante, mostrando-se, dessa forma, um professor aberto a ideias. Assim afirma, Freire (1987): 
assim, se tornam sujeitos do processo em que crescem juntos e em que os "argumentos de autoridade" já não valem (FREIRE, 1987, p. 39).

Freire (1987) valoriza o diálogo no aprendizado. Ele destaca que educador e educando são sujeitos do mesmo processo: ambos se educam ao educar. A figura do professor não é mais uma autoridade que o separa, que o distancia do aluno, mas se mistura e se confunde no processo educativo. São conhecimentos que crescem juntos, são construídos por meio do diálogo que permite que ambos conheçam-se e respeitem-se como sujeitos aprendizes.

Ser um educador social em projetos sociais envolve mais do que o processo de transmissão de conteúdo, é trabalhar para a cidadania e a transformação social dos alunos e reconhecer que seu papel vai além de ensinar conteúdos, mas ajudar os alunos a conviver uns com os outros, a compreender as condições existentes para aprender com suas experiências e desenvolver autonomia. Exige querer bem aos educandos, é não ter medo de expressar a sua afetividade de um modo que não interfira no seu comportamento ético.

Ser educador é ser professor e estar aberto ao diálogo com os alunos ou, como afirma Hikiji (2006), saber explorar o seu lado humano. A autora destaca o comportamento dos educadores observados em sua pesquisa no projeto Guri. Eles trabalham a autoestima dos alunos por meio da música e dialogam com eles, incentivando-os e valorizando o talento de todos para a música, como uma forma de demonstrar que são importantes e únicos. A música devolve aos alunos algo bom, resgata sua humanidade. $\mathrm{O}$ educador tem um papel muito importante nessa formação, pois, como afirma Hikiji (2006):

\footnotetext{
Em geral, o professor de música que é contratado pelo Projeto Guri sabe que não irá somente ensinar música, mas como lembra o maestro no início deste capítulo, irá conversar, dar atenção e trocar experiências com crianças e jovens que nem sempre "ouviram um bom dia ao sair de casa" (HIKIJI, 2006, p. 136).
}

O professor torna-se um conselheiro e cria um clima favorável para o diálogo. Hikiji (2006, p. 133), ao pesquisar um centro de internação de jovens infratores, também observa o educador como o conselheiro que orienta e que procura conscientizá-los para um caminho melhor distante do caminho do crime.

A educação de atitudes e comportamento também é destacada por Cruvinel (2005, p. 155), que, ao realizar uma intervenção-aula no Centro Especializado em Atendimento à Criança e ao Adolescente (CEACA), constatou que além de trabalhar a educação musical nesse lugar, ela teria que trabalhar também a educação geral, pois os alunos eram 
indisciplinados e tinham dificuldades de concentração. Ao ensinar música ela percebeu que, primeiramente, teria que trabalhar a disciplina dos alunos, ou seja, conversar, ensiná-los a se comportarem e a se concentrarem na aula. O diálogo foi a estratégia utilizada para educar e aprender. Durante as aulas de música, a autora realizava alguns momentos de roda de conversa, em que eram discutidos assuntos voltados ao comportamento social na instituição.

As situações de conflito também são relatadas por Almeida (2005, p. 76), que destaca o desenvolvimento do conhecimento prático do oficineiro na resolução de problemas. Esse conhecimento é construído no dia a dia com os alunos e as situações que envolvem disciplina e discussões sobre temas relacionados a "sexo, drogas, violência, família, consciência de vida, religião e relacionamentos [...]” (ALMEIDA, 2005, p. 68). A autora destaca a importância de se trabalhar com a "autoestima" e a "inclusão social". Em suas palavras, percebe-se o aprendizado prático dos oficineiros associado à disciplina e à transformação de comportamentos:

\footnotetext{
Jogo de cintura é também um dos termos utilizados pelas professoras de música investigadas por Beneike (2000, p. 153) para designar as tomadas de decisões necessárias em situações inesperadas em sala de aula, como resolver brigas entre colegas. E isso está sendo um grande aprendizado para o oficineiro na condução da oficina, pois as crianças não têm o mesmo nível de concentração dos adolescentes, e estes, que no princípio o testavam, agora procuram ajudar na disciplina. (ALMEIDA, 2005, p. 76).
}

Portando, autoestima e disciplina são conteúdos trabalhados pelos educadores sociais. Geralmente, eles encontram alunos oriundos de experiência de exclusão e de carência afetiva. Muitas vezes, eles são moradores de rua, sem uma estrutura familiar, o que pode fazer com que desenvolvam uma baixa autoestima. Isso normalmente desafia o educador em sala de aula e o faz criar condições favoráveis ao diálogo em momentos de convivência com os alunos, momentos de conscientização a respeito da realidade que vivem e da possibilidade de conquistarem uma vida melhor em sociedade e exercerem seus direitos como cidadãos.

Hikiji (2006), Cruvinel (2005) e Almeida (2005) compartilham a concepção de que o ensino de música nos contextos não formais visa, principalmente, a transformação social e o educador tem o grande desafio de conduzir e promover essa transformação. Nesses contextos, os próprios alunos se tornam agentes de transformação ao se tornarem multiplicadores no projeto. Os multiplicadores são formados pelos próprios professores de música em ONGs e desenvolvem habilidades musicais e de liderança.

O capítulo apresentou as características da educação não formal no contexto dos projetos sociais em que os mediadores, facilitadores, multiplicadores, tutores, monitores são 
educadores sociais que atuam como parte da construção, da mediação e da organização das metodologias, construídas a partir de um problema identificado juntamente com intencionalidade de cada projeto. O convívio social e o diálogo são vistos como importantes na interação dos educadores com os alunos, pois neles os planos sociais e emocionais, segundo Gohn (2010), ocorrem nas aprendizagens cotidianas. Assim o educador musical como educador social deve ensinar não somente a técnica instrumental como instrutor, mas deve intervir no mundo, como recomenda Freire (2011). O educador musical como educador social deve promover a cidadania e a transformação social, desenvolvendo a autonomia dos educandos e aprendendo a ensinar, nesses locais, a partir de suas próprias experiências e interações.

\subsection{A DIVULGAÇÃO E SOCIALIZAÇÃO DE SABERES: O PAPEL DOS MULTIPLICADORES}

Os multiplicadores como mediadores e replicadores de saberes e práticas estão associados às práticas educativas em diversas áreas do conhecimento, como saúde, informática, meio ambiente, psicologia, arte educação e cidadania. Seu papel é a replicação do que é aprendido, do que é projetado, do que deve ser ensinado expandindo as informações e criando subsídios para que elas sobrevivam e permaneçam vigentes por mais tempo.

$\mathrm{Na}$ área de saúde, por exemplo, multiplicadores, são formados para a prevenção de doenças. Moskovics e Calvetti, (2008) desenvolveram um trabalho em uma universidade espanhola voltado para a educação preventiva das pessoas. $\mathrm{O}$ trabalho foi realizado, visando à mudança de comportamento das pessoas em relação a $\operatorname{DSTs}^{6}$ como a $\operatorname{AIDS}^{7}$, por exemplo (MOSKOVICS; CALVETTI, 2008, p. 213). Nesse trabalho de prevenção, o papel do multiplicador é ampliar a discussão sobre $\operatorname{HIV}^{8}$ /AIDS para pessoas que estão vulneráveis psicologicamente e socialmente.

$\mathrm{Na}$ área turística, Barbosa (2002) identifica o multiplicador como um dos conceitos econômicos utilizados para a tomada de decisões no desenvolvimento de setores. Fletcher (apud BARBOSA, 2002) afirma que "o conceito do 'multiplicador' é baseado no reconhecimento de que as vendas de uma firma levam-na a comprar produtos e serviços de

\footnotetext{
${ }^{6}$ DSTs: Doenças Sexualmente TransmitidasAIDS: Síndrome da Imunodeficiência Adquirida, em inglês Acquired Immunodeficiency Syndrome.

${ }^{7}$ AIDS: Síndrome da Imunodeficiência Adquirida, em inglês Acquired Immunodeficiency Syndrome.

${ }^{8}$ Vírus da Imunodeficiência Humana. Em inglês: Human Immunodeficiency Virus.
} 
outras, dentro da economia local, ou seja, os setores econômicos são interdependentes" (BARBOSA, 2002, p. 04).

Segundo Marra (2005, p. 14), o multiplicador é aquele que interage e reflete ao se deparar com situações tanto de ordem como desordem, organização ou desorganização da comunidade em que atua vivendo assim situações de imprevisibilidade, característica dos projetos com o objetivo de transformação social. A autora defende a ideia de que o conhecimento do multiplicador é construído na prática, em suas experiências na comunidade, com o compromisso social.

Marra (2005) afirma que é possível formar e capacitar pessoas para serem multiplicadores, aptos a elaborar e executar um projeto na área da saúde mental. A autora afirma que o multiplicador é um construtor e reconstrutor, pois compartilha com todos a visão de um problema identificado, além de possuir competência transformadora. A sua atuação, não segue um modelo único de intervenção, pois o multiplicador se adequa a vários aspectos da verdade que se manifesta em um determinado grupo. Sua ação está alicerçada na proposta de que aquele que cuida nem sempre deve ser formado, especialista para atuar como multiplicador (MARRA, 2005, p. 12-13).

$\mathrm{Na}$ área da educação musical, Kleber (2006d, p. 209) afirma que o multiplicador é o monitor que aprende, por meio de ações pedagógicas dos educadores, a ensinar música para os alunos de uma determinada ONG pesquisada pela autora. Esse multiplicador aprendeu a dar aulas de música na prática, no contexto da ONG, afirma Kleber (2006d, p. 209). Um educador da ONG prepara o multiplicador orientando para a prática.

O exercício de ser multiplicador, envolve alguns elementos, como o prazer em ensinar e aprender. Esse exercício incentiva tanto o multiplicador como o aluno que está iniciando. Ambos sentem prazer em estudar. Sobre isso, Cortella (2002) afirma que:

\footnotetext{
O segredo está no prazer. O que não pode haver na escola e na ONG é a tristeza, porque não há conhecimento que venha a partir do desprazer. O desprazer gera sofrimento, podendo levar o aprendizado ao famoso "aprender na marra" (CORTELLA, 2002, p. 96).
}

Segundo o autor, o prazer está associado ao aprendizado, à alegria, e eles caminham junto com o trabalho dos multiplicadores que promovem a cidadania e a transformação social em uma determinada ONG. Esse trabalho para a transformação social não é realizado somente na ONG, mas na escola também. Cortella afirma que há dois tipos de aprendizagem: a ocasional, que ocorre no decorrer da vida, e a intencional, que se dá na escola ou em ONGs. 
$\mathrm{O}$ autor posiciona os educadores na parte intencional e alerta que eles correm o risco de serem artificiais, tanto na escola como em ONGs. Mas também destaca a vantagem de sua eficácia. O aprendizado acontece mais rápido, pois é planejado e metódico. A vantagem da aprendizagem ocasional é sua "maior significação". Para Cortella, uma boa aprendizagem é aquela que inclui esses dois tipos de aprendizagem: a ocasional e a intencional.

A ONG não deve ser um local em que se aprende apenas de forma ocasional. Ela não pode abrir mão de passar adiante conteúdos fundamentais para o enfrentamento do mundo. E não se trata apenas de conteúdos científicos, mas também ligados à música, à estética, à religião e à sensibilidade (CORTELLA 2002, p. 99-100).

O autor afirma que a escola não é a única instituição que pode lidar com a educação e é falso falar que ela está sendo desvalorizada. O fortalecimento da escola também fortalece a ONG. Cortella enfatiza a aprendizagem eficaz no seu sentido prático e ressalta a qualidade total que a educação ligada ao fato social pode gerar. A eficácia que Cortella defende diz respeito a algo que deve ser pensado socialmente. Então ele explica que não é algo que é pensado individualmente, mas em conjunto, em que o objetivo da educação seja fortalecer a vida no e do outro.

A finalidade central da educação é fazer com que sejamos, todas e todos, capazes de permitir que o outro e a outra sejam mais fortes para existir. Mede-se eficácia por isso. Todas às vezes, numa escola ou numa $\mathrm{ONG}$, em que meu trabalho diminui a capacidade vital de alguém estou sendo menos eficaz (CORTELLA, 2002, p. 100).

O autor ressalta o caráter social dessa eficácia e afirma que ela se mede pela capacidade de fortalecer a vida. É importante que o educador se avalie para que possa identificar o que pode ser melhorado. Cortella diz que os homens e as mulheres precisam melhorar no campo intencional e na eficácia social. O autor apresenta a palavra Sinergia, que vem do grego e significa "força junto". Para Cortella, deve haver essa "força junto", que funciona quando acompanhada de sintonia e simpatia, ou seja, "desta forma, a primeira relação simpática é a capacidade de olhar o outro como outro, e não como um estranho" (CORTELLA, 2002, p.101).

Segundo o autor, na atualidade há uma tendência à separação, ou seja, colocar ONGs de um lado e a escola de outro, como se fosse possível separá-las. Segundo o autor, essa separação contribui para a exploração econômica do Estado, o que gera a violência urbana.

Isso só pode ser combatido se percebermos a necessidade de trabalhar de forma articulada. Saber permutar nossas experiências, ser capaz de olhar o outro como outro, 
de ter humildade pedagógica, de aprender com o outro e ensinar o outro (CORTELLA, 2002, p. 101).

Para o autor, aprender na ONG e na escola significa que queremos fazer melhor. Tanto a ONG quanto a escola precisam aprender uma com a outra. Quando mais se aprende, mais se adquire a eficácia social.

Nos projetos, o professor constata que o aluno realmente aprendeu quando a aprendizagem acontece de forma prazerosa, com alegria, no convívio social. Os que não querem aprender dificilmente terão prazer e alegria em fazer um acorde no violão ou uma nota numa flauta doce.

No Instituto Batucar, o "projeto multiplicadores" conta com alunos, aprendizes que estão dispostos a dar continuidade ao ensino e à aprendizagem da música no IB. São crianças e adolescentes que ensinam e aprendem, na prática do dia a dia, a ser multiplicador. Eles são formados e orientados pelos educadores do IB. Seu papel principal é multiplicar, facilitar o aprendizado dos alunos, promover a cidadania e a transformação social, levar a cultura local para a região e sustentar a cultura local promovendo a continuidade dos trabalhos como educadores musicais.

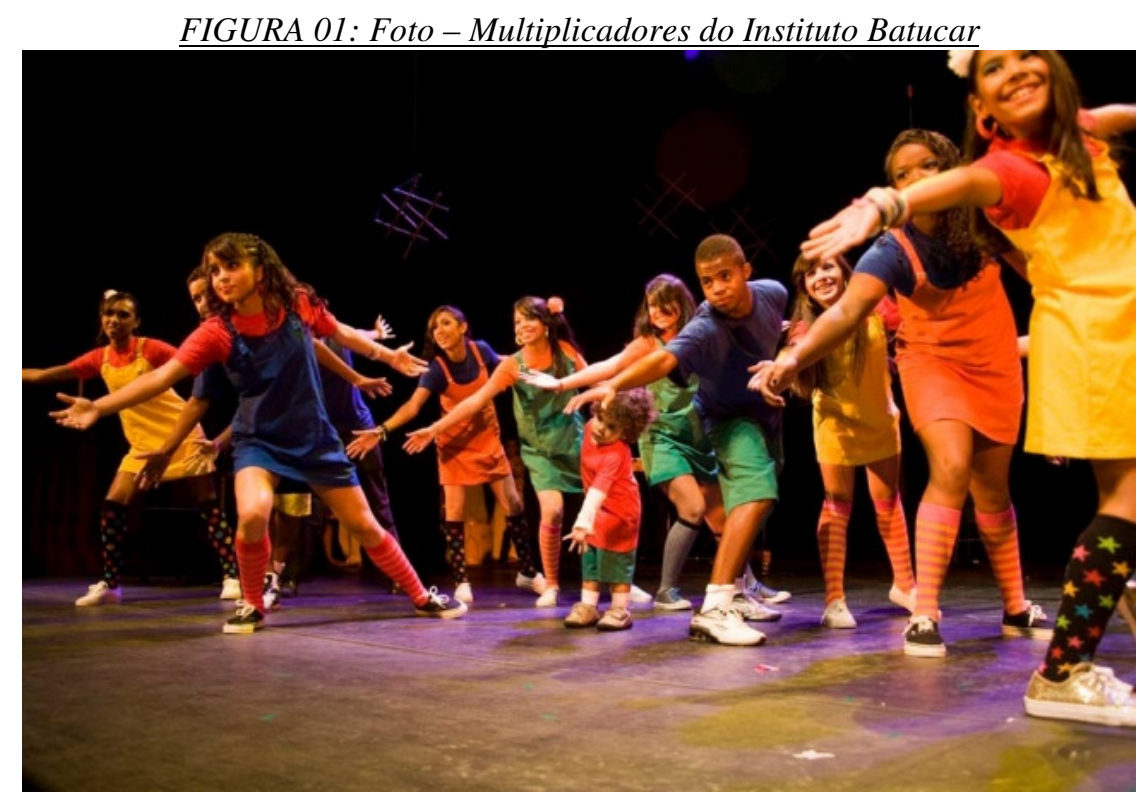

Fonte: Google imagens 


\section{METODOLOGIA}

Compreender a atuação dos multiplicadores no projeto social Instituto Batucar (IB), descrever as práticas musicais desenvolvidas; identificar as estratégias pedagógico-musicais dos multiplicadores e conhecer como eles percebem sua atuação no projeto são objetivos que exigem um contato direto e contínuo com a OSCIP. Nesse sentido, esta investigação se caracteriza como um estudo qualitativo do tipo estudo de caso em que a unidade de estudo é a atuação dos multiplicadores.

\subsection{O ESTUDO DE CASO}

Para Gil (2002, p. 54), o estudo de caso era considerado, antigamente, como um método pouco rigoroso, utilizado somente para estudos de natureza exploratória. Hoje, ele é utilizado para investigação de fenômenos contemporâneos. Segundo esse autor, o estudo de caso é utilizado em áreas como as ciências biomédicas e sociais e pode caracterizar um estudo piloto, exploratório, para identificar as questões da pesquisa. As questões e os resultados, de um modo geral, são mostrados em aberto, não como conclusões, mas como hipóteses. Gil (2002, p. 54) afirma que a utilização desse método se dá a partir de diferentes propósitos como:

\footnotetext{
a) explorar situações da vida real cujos limites não estão claramente definidos;

b) preservar o caráter unitário do objeto estudado;

c) descrever a situação do contexto em que está sendo feita determinada investigação;

d) formular hipóteses ou desenvolver teorias; e

e) explicar as variáveis causais de determinado fenômeno em situações muito complexas que não possibilitam a utilização de levantamentos e experimentos.
}

Esses propósitos são bastante utilizados em pesquisas nas ciências sociais. No entanto, há muitas objeções à metodologia do estudo de caso. Uma delas, destacada anteriormente, é a "falta de rigor metodológico" (GIL, 2002, p. 54). Isto porque o estudo de caso investiga o particular e não viabiliza a generalização para outros contextos, como ocorre com estudos quantitativos.

A pesquisa utilizando o estudo de caso é um tipo de pesquisa considerada "fácil", pelo fato de lidar com poucas unidades, segundo Alves-Mazzoti (2006). A autora o caracteriza como um estudo que focaliza: 
[...] apenas uma unidade: um indivíduo (como os "casos clínicos" descritos por Freud), um pequeno grupo (como o estudo de Paul Willis sobre um grupo de rapazes da classe trabalhadora inglesa), uma instituição (como uma escola, um hospital), um programa (como o Bolsa Família), ou um evento (a eleição do diretor de uma escola) (ALVES-MAZZOTTI, 2006, p. 640).

Ao estudar uma unidade ou indivíduo, a autora afirma que há possibilidades do mesmo estudo de caso ser estudo de casos múltiplos em que vários estudos são conduzidos simultaneamente como, por exemplo, um estudo de caso com vários indivíduos ou várias instituições que desenvolvem vários projetos dentro do mesmo local (ALVES-MAZZOTTI, 2006, p. 640-641). Assim, os estudos de caso podem ser únicos ou múltiplos.

$\mathrm{Na}$ mesma linha investigativa, André (2000) afirma que o pesquisador, ao selecionar uma unidade de caso, a delimita para compreendê-la como unidade a ser estudada. A autora destaca que é importante que o estudo de caso:

[...] seja um sistema bem delimitado, isto é, uma unidade com limites bem definidos, tal como uma pessoa, um programa, uma instância de uma classe ou porque é por si mesmo interessante. De qualquer maneira o estudo de caso enfatiza o conhecimento do particular. $\mathrm{O}$ interesse do pesquisador ao selecionar uma determinada unidade é compreendê-la como uma unidade. Isso não impede, no entanto, que ele esteja atento ao seu contexto e às suas inter-relações como um todo orgânico, e à sua dinâmica como um processo, uma unidade em ação (ANDRÉ, 2000, p. 31).

Segundo André (2000), o interesse de pesquisadores e estudiosos ao coletar dados de determinado grupo social tem seu fim na compreensão do processo educativo. A autora aponta algumas características importantes da pesquisa qualitativa que utiliza o estudo de caso. São elas: "ênfase no processo, naquilo que está ocorrendo e não no produto ou nos resultados finais"; "preocupação com o significado, com a maneira própria com que as pessoas veem a si mesmas, as suas experiências e o mundo que as cerca”. Outra característica da pesquisa com estudo de caso se refere ao contato direto com o objeto de estudo, ou seja, “envolve um trabalho de campo" (ANDRÉ, 2000, p. 29). Por fim, a autora afirma que essa modalidade de pesquisa "busca a formulação de hipóteses, conceitos, abstrações, teorias e não sua testagem" (ANDRÉ, 2000, p. 31).

Portanto, esta pesquisa se caracteriza como estudo de caso por que apresenta as seguintes características: 1) imersão no campo de pesquisa; 2) observação natural e participante; 3) contato direto com os participantes da pesquisa e interação por meio de entrevistas; 4) análise interpretativa das falas dos participantes da pesquisa e 5) preocupação com os sentidos e significados que eles atribuem às suas vivências. Como técnicas de 
pesquisa, este estudo envolveu observação participante, entrevista semiestruturada individual e coletiva (grupo focal) e análise de documentos e do site do IB.

Com relação às entrevistas, ao abordar a entrevista individual numa pesquisa qualitativa, Montandon (2008) afirma que essa técnica em educação musical é recorrente. A autora destaca que por meio desse instrumento podem-se desenvolver duas estratégias de investigação: 1) como uma metodologia de pesquisa ou 2) como uma técnica dentro de outros métodos para buscar dados na pesquisa. Para a pesquisadora a entrevista é uma importante ferramenta em que são obtidos dados para produzir novos conhecimentos.

André (2000) também destaca a importância dessa técnica para aprofundar a interação e as informações sobre a unidade de estudo:

\footnotetext{
As entrevistas têm a finalidade de aprofundar as questões e esclarecer os problemas observados. Os documentos são usados no sentido de contextualizar o fenômeno, explicar suas vinculações mais profundas e completar as informações coletadas através de outras fontes (ANDRÉ, 2000, p. 29).
}

A outra técnica de entrevista utilizada nesta pesquisa foi a entrevista com grupo focal. Segundo Dias (2002), o objetivo geral do grupo focal é identificar algumas atitudes como a percepção e os sentimentos dos participantes a respeito de um assunto determinado pelo pesquisador. As especificações e diferenciações de estratégias nesse instrumento podem variar conforme a abordagem metodológica que a pesquisa segue. A autora ainda afirma que, quando aplicado em pesquisas exploratórias, seu objetivo é gerar novas hipóteses e ideias, o que favorece o estímulo do pensamento do pesquisador.

Sobre o número de entrevistados e a organização do ambiente, Bauer e Gaskell (2011) afirmam:

O grupo focal tradicional compreende seis a oito pessoas desconhecidas anteriormente, que se encontram em um ambiente confortável por um tempo entre uma a duas horas. Os participantes e o moderador sentam num círculo, de tal modo que possa haver um contato frente a frente entre cada um. Quando as pessoas se sentam, a primeira tarefa do moderador é apresentar a si próprio, o assunto e a ideia de uma discussão grupal (BAUER; GASKELL, 2011, p. 79).

Na visão de Dias (2002), o grupo focal pode ser constituído de seis a oito pessoas selecionadas e relacionadas com o tema a ser discutido pelo pesquisador. A discussão do grupo dura aproximadamente duas horas e é conduzida por um moderador que pode ser o pesquisador. Segunda a autora, o discurso à vista dos participantes é flexível, sem uma estrutura. Sob o ponto de vista do moderador, a discussão é estruturada e não é tão flexível, 
pois há um planejamento prévio por parte do moderador, considerando os objetivos da pesquisa. Dias (2002) afirma que a função do moderador no grupo focal é direcionar todo o discurso. Caso haja, na reunião, um desvio do assunto que está sendo tratado, ele deve agir sem interromper de forma brusca o participante.

Bauer e Gaskell (2011) também destacam a importância do moderador no grupo focal. Para eles "o moderador encoraja ativamente todos os participantes a falar e a responder aos comentários e observações dos outros membros do grupo" (BAUER; GASKELL, 2011, p. 79).

A outra técnica investigativa utilizada nesta pesquisa foi a observação participante. Sobre essa estratégia, André (2000) afirma que "a observação é chamada participante porque parte do princípio de que o pesquisador tem sempre um grau de interação com a situação estudada, afetando-a e sendo por ela afetado" (ANDRÉ, 2000, p. 29).

Segundo Valladares (2007), esse tipo de técnica requer um tempo longo e é uma fase exploratória. A observação participante, segundo a autora, exige tempo para que o pesquisador observe e compreenda os comportamentos das pessoas de um determinado grupo, o que não ocorre em uma única observação. Nesse tipo de observação, a autora afirma que o pesquisador cai de "paraquedas" no campo a ser pesquisado e, muitas vezes, não é esperado pelo grupo visitado. Valladares (2007) ressalta também, como André (2000), que esse tipo de técnica de pesquisa supõe uma interação entre pesquisador e pesquisado. A presença do pesquisador deve ser justificada, pois sobre ele permeia a curiosidade, quando não a desconfiança. No campo de pesquisa, o pesquisador deve se mostrar diferente das pessoas que estão sendo pesquisadas e sua observação participante não se realiza sem um documento, uma autorização do campo a ser pesquisado.

No trabalho de observador participante, o pesquisador também é observado e esse fato é, algumas vezes, ignorado pelo pesquisador no campo, que quase desconhece sua imagem junto aos membros pesquisados. Ainda segundo Valladares (2007), a observação participante aliada à técnica de entrevistas implica saber ouvir, observar, perguntar na hora certa, calar e utilizar todos os sentidos de observação e escuta.

No estudo de caso, é importante que o pesquisador organize uma rotina de campo. Elementos como anotações no diário de campo são importantes para o desenvolvimento da autodisciplina durante a pesquisa. A presença constante do pesquisador no campo aumenta a confiança dos participantes em relação ao seu trabalho. Contudo, alguns erros podem ser cometidos durante a realização de uma pesquisa. Assim, a autora afirma que o pesquisador aprende com os erros, pois eles trazem uma reflexão sobre o porquê de uma recusa ou de um 
acontecimento. Ele também é cobrado pela devolução da pesquisa e, dos resultados obtidos por parte dos pesquisados.

\subsection{A EXPERIÊNCIA DE CAMPO NO BATUCAR}

O trabalho de campo envolve mais o aprofundamento das questões de pesquisa do que as características de uma comunidade. Por isso, segundo Gil (2002), o planejamento no estudo de campo é flexível e pode ocorrer, inclusive, para que os objetivos sejam construídos durante a pesquisa. Segundo o autor, nessa técnica, observa-se "[...] um único grupo ou comunidade em termos de sua estrutura social, ou seja, ressaltando a interação entre seus componentes. Dessa forma, o estudo de campo tende a utilizar muito mais técnicas de observação do que de interrogação" (GIL, 2002, p. 53). O autor explica que o trabalho de campo envolve o estudo de uma comunidade, em que as técnicas de observação prevalecem e orientam outras técnicas de pesquisa como as entrevistas, por exemplo. A seguir apresento os participantes desta investigação e os procedimentos desenvolvidos na pesquisa no Instituto Batucar (IB).

\subsubsection{Os participantes da pesquisa: a equipe do Instituto Batucar}

Atualmente, no Instituto Batucar o idealizador e coordenador do projeto é o professor de música Roberto Ricardo Santos de Amorim, 48 anos, que é Licenciado em Educação Artística- Música pela Universidade de Brasília. Ele iniciou seus estudos de violão na Escola de Música de Brasília (CEP-EMB), entre 1988 e 1990. Logo depois, ingressou no Conservatório de Música Popular Brasileira (MPB) de Curitiba onde estudou arranjo instrumental, harmonia e improvisação, solfejo e rítmica, no período de 1997 a 1999. A Percussão Corporal entrou em sua formação quando fez um curso com o grupo Barbatuques, em 1999, na cidade de São Paulo. Ricardo criou o grupo de performance Batucadeiros aos 35 anos e há 13 anos é responsável pelas atividades pedagógico-musicais no Instituto Batucar.

Patrícia Carvalho de Amorim é a coordenadora pedagógica do IB. Atualmente com, 42 anos, ela começou aos 29 anos, ao lado de Ricardo, o projeto Batucar. Na sua formação musical, entre 1998 a 2002, estudou flauta transversal na Escola de Música de Brasília. No Instituto ela cuida da parte dos agendamentos das atividades pedagógico-musicais e das apresentações artísticas dos Batucadeiros. 
O administrador do IB é o ex-aluno Alceu Avelar de Araújo. Ele ingressou no Instituto Batucar aos 17 anos, estudou violão e percussão corporal no Instituto Batucar e foi monitor. Hoje aos 30 anos, é formado em administração, com o apoio do IB e cuida de toda a parte administrativa do Instituto.

André Soares dos Santos entrou no Instituto Batucar aos 14 anos, foi aluno, multiplicador e hoje, é educador musical. Ele ministra aulas de violão e percussão corporal, orienta os multiplicadores em suas atividades e colabora nas aulas de orquestra. $\mathrm{O}$ educador que tem 28 anos de idade, está no Instituto Batucar há 13 anos. Dos 14 aos 25 anos, estudou no próprio IB: violão, guitarra, teclado, contrabaixo elétrico, violino, viola de arco, violoncelo e percussão corporal. Há um ano estuda violoncelo na EMB e atualmente está no $3^{\circ}$ semestre do curso de Licenciatura em Música da UnB.

Da mesma forma que André e Alceu, Giselle Luisa Galdino Pereira entrou no IB aos 20 anos e há 13 anos colabora com o Instituto. Hoje com 33 anos, ela é formada em pedagogia com o apoio do IB e desenvolve acompanhamento pedagógico com os alunos do projeto que têm dificuldades escolares, além de ensinar percussão corporal no IB e no CEF113/Recanto das Emas. Ela estudou violão, violoncelo e percussão corporal no IB e há 2 anos estuda violoncelo na EMB.

Os participantes autorizaram revelar seus nomes, assim como suas falas por meio formal e carta de consentimento esclarecido de pesquisa. Os multiplicadores receberam autorização de seus pais para participar da pesquisa por meio de uma carta de autorização, mas seus nomes são fictícios para preservar a identidade dos menores.

Os multiplicadores participantes desta pesquisa são 12 jovens, com idades entre $13 \mathrm{e}$ 17 anos, moradores do Recanto das Emas. De modo geral, eles frequentam o Instituto Batucar entre 4 meses a 8 anos. Na instituição eles aprendem percussão corporal, violão, violoncelo e desenvolvem um trabalho de monitoria, motivo pelo qual são conhecidos como multiplicadores. Nesta pesquisa seus nomes são fictícios por serem menores e para preservar suas identidades.

No quadro a seguir é apresentado os multiplicadores, seus nomes fictícios, idade e tempo de vivência no Instituto Batucar:

Quadro 1- Os Multiplicadores do Instituto Batucar

\begin{tabular}{|l|l|c|}
\hline \multicolumn{1}{|c|}{ PARTICIPANTES } & \multicolumn{1}{c|}{ IDADE } & TEMPO NO INSTITUTO BATUCAR \\
\hline ÉMILE & 15 anos & 8 anos \\
\hline RAÍSSA & 14 anos & 8 anos \\
\hline HENRIQUE & 14 anos & 8 anos \\
\hline
\end{tabular}


$\underline{\text { (continuação) }}$

Quadro 1- Os Multiplicadores do Instituto Batucar

\begin{tabular}{|l|l|c|}
\hline DIOGO & 16 anos & 4 meses \\
\hline LUCIANA & 13 anos & 2 anos \\
\hline PAULO & 13 anos & 7 anos \\
\hline LEONARDO & 17 anos & 6 anos \\
\hline ROSELI & 16 anos & 6 anos \\
\hline MATHEUS & 17 anos & 5 anos \\
\hline MILENA & 15 anos & 5 anos \\
\hline VÂNIA & 15 anos & 8 meses \\
\hline PLÍNIO & 15 anos & . \\
\hline
\end{tabular}

\subsubsection{As observações}

Iniciei as observações no IB em fevereiro de 2013, quando visitei o Instituto pela primeira vez. Nesta ocasião, fui convidada a entrar e percebi que todos os participantes estavam em reunião. O coordenador do Instituto me recebeu e todos se apresentaram, contando resumidamente sobre sua atuação no IB. Eu me apresentei e expliquei como seria o estudo de campo naquele local. Conversamos durante dez minutos e, nesse encontro, percebi que o IB estava de portas abertas para a realização desta pesquisa. Em seguida, fui convidada para uma reunião de pais que aconteceria no dia 24 de fevereiro de 2013. Aceitei o convite e tratei de providenciar uma autorização formal por meio de uma carta da Universidade de Brasília - UnB ${ }^{9}$, formalizando a minha pesquisa no IB. A reunião de pais ocorreu na tenda de atividades do projeto, espaço onde ocorrem também as aulas de percussão corporal. A partir desse primeiro contato, comecei a participar das atividades do projeto uma vez por semana, com os alunos nas aulas de percussão corporal e de violão. Em prosseguimento às atividades de observação, acompanhei as atividades que o IB realiza na Educação Básica, Centro de Ensino Fundamental 113 - Recanto das Emas (CEF 113), escola pública local, como atividade extracurricular no projeto Mais Educação, projeto de educação integral.

No início das observações, percebi um estranhamento por parte dos profissionais e alunos, por eu estar ali. Mas, aos poucos, com o passar dos dias, todos foram se acostumando com a minha presença e cultivamos uma amizade. A partir desse momento, a comunidade aceitou minha presença com mais naturalidade, principalmente os alunos.

O Quadro 02 a seguir mostra os dias das observações participantes que aconteceram no IB durante o ano de 2013, totalizando 43 horas de trabalho de campo.

\footnotetext{
${ }^{9}$ Apêndice A, encontrado na página 99.
} 
Quadro 02 - Dias e duração das observações participantes no Instituto Batucar

\begin{tabular}{|c|c|c|}
\hline $\begin{array}{l}\text { INSTITUTO } \\
\text { BATUCAR/ } \\
\text { C.E.F. } 113- \\
\text { DATAS }\end{array}$ & ATIVIDADES NO CAMPO & $\begin{array}{l}\text { DURAÇÃO } \\
\text { E } \\
\text { TOTAL: } \\
\text { 50h20min }\end{array}$ \\
\hline $18 / 02 / 13$ & Primeiro contato com o IB. & $10 \mathrm{~min}$ \\
\hline $24 / 02 / 13$ & Reunião de pais & $2 \mathrm{~h} 30 \mathrm{~min}$ \\
\hline $05 / 03 / 13$ & Aula de solfejo com a música "Berimbau" & $1 \mathrm{~h} 40 \mathrm{~min}$ \\
\hline $19 / 03 / 13$ & Aula de canto com a música "Berimbau" & $1 \mathrm{~h} 40 \mathrm{~min}$ \\
\hline $12 / 03 / 13$ & Solfejo com as notas da música "Aquarela" & 1h40min \\
\hline $26 / 03 / 13$ & Aula de técnica vocal, percussão corporal e violão & $1 \mathrm{~h} 40 \mathrm{~min}$ \\
\hline $02 / 04 / 13$ & Aula de técnica vocal e violão & $1 \mathrm{~h} 40 \mathrm{~min}$ \\
\hline $09 / 04 / 13$ & Aula de técnica vocal & $1 \mathrm{~h} 40 \mathrm{~min}$ \\
\hline $16 / 04 / 14$ & Aula de percussão corporal & $1 \mathrm{~h} 40 \mathrm{~min}$ \\
\hline $23 / 04 / 13$ & $\begin{array}{l}\text { Aula de percussão corporal, jogos com a percussão em que os alunos eram } \\
\text { separados por grupos. }\end{array}$ & 1h40min \\
\hline $30 / 04 / 13$ & $\begin{array}{l}\text { Aula de percussão corporal, aquecimento do corpo, repetição de exercícios } \\
\text { propostos pelo educador, "o passo". }\end{array}$ & 1h40min \\
\hline $07 / 05 / 13$ & $\begin{array}{l}\text { Aula de percussão corporal, percussão com a música “Escravos de Jó”. } \\
\text { Ensaio com instrumentos ministrados pelos multiplicadores. }\end{array}$ & $1 \mathrm{~h} 40 \mathrm{~min}$ \\
\hline $21 / 05 / 13$ & Agendamento das entrevistas & $30 \mathrm{~min}$ \\
\hline $27 / 05 / 13$ & Aula de percussão corporal no C.E.F.113/Rec.Emas & $1 \mathrm{~h} 30 \mathrm{~min}$ \\
\hline 03/06/13 & Aula de percussão corporal com o exercício "pergunta e resposta" & 1h30min \\
\hline $11 / 06 / 13$ & $\begin{array}{l}\text { Aula percussão corporal, como o exercício "pergunta e resposta”, exercícios } \\
\text { propostos com a imitação dos alunos. Aula de violão com acordes sem e } \\
\text { com pestana de uma música evangélica /Reunião pedagógica - Discussão } \\
\text { sobre as aulas de música no IB com os multiplicadores e incentivo à gestão } \\
\text { colaborativa. }\end{array}$ & $\begin{array}{l}\text { 1h40min }+ \\
1 \mathrm{~h} 20 \mathrm{~min}\end{array}$ \\
\hline $13 / 06 / 13$ & Aula de percussão corporal e entrevista & $\begin{array}{l}1 \mathrm{~h} 40 \mathrm{~min} \\
1 \mathrm{~h}\end{array}$ \\
\hline $24 / 06 / 13$ & Aula de violão, ensino de acordes da música "Pais e Filhos". & 1h30min \\
\hline $01 / 07 / 13$ & Aula de percussão corporal & $1 \mathrm{~h} 40 \mathrm{~min}$ \\
\hline $09 / 07 / 13$ & $\begin{array}{l}\text { Aula de percussão corporal/Reunião pedagógica sobre as aulas no IB e na } \\
\text { escola pública. }\end{array}$ & 1h40min \\
\hline $20 / 08 / 13$ & $\begin{array}{l}\text { Aula de percussão corporal e reunião pedagógica em que foi discutido } \\
\text { agenda do IB. }\end{array}$ & $\begin{array}{l}1 \mathrm{~h} 40 \mathrm{~min}+ \\
1 \mathrm{~h} 20 \mathrm{~min}\end{array}$ \\
\hline $09 / 10 / 13$ & $\begin{array}{l}\text { Percussão corporal: Alongamento do corpo, "pergunta e resposta", "flecha", } \\
\text { "o passo", percussão corporal e canto da música "Penedo vai, penedo } \\
\text { vem"/Ensaio com os multiplicadores. }\end{array}$ & $\begin{array}{l}\text { 1h40min }+ \\
1 \mathrm{~h} 20 \mathrm{~min}\end{array}$ \\
\hline $11 / 10 / 13$ & $\begin{array}{l}\text { Aula de percussão corporal: massagem no colega do lado, exercício de } \\
\text { relaxamento chamado de "Karatê". Exercício "pianinho" que consiste em } \\
\text { tocar apenas com a ponta dos dedos no ombro do outro, massageando. } \\
\text { Exercícios da "Flexa", da "pergunta e resposta", percussão usando as partes } \\
\text { do corpo: peito, palma, barriga, pés e sons com a boca. }\end{array}$ & \\
\hline $15 / 10 / 13$ & Não houve aula & $\begin{array}{l}10 \mathrm{~min}(\mathrm{de} \\
\text { espera })\end{array}$ \\
\hline $18 / 10 / 13$ & $\begin{array}{l}\text { Aula de orquestra com violinos, exercícios de ritmos } 2 / 4 \text { e } 4 / 4 \text { para violino } \\
\text { na partitura e melodias executadas a duas e três vozes para violinos. }\end{array}$ & 1h40min \\
\hline $21 / 10 / 13$ & $\begin{array}{l}\text { Aula de percussão corporal no C.E.F.113/Rec.Emas. Alongamento do corpo, } \\
\text { exercícios de imitação, percussão corporal da música "Caranguejo não é } \\
\text { peixe" e "Ciranda Cirandinha". Dança das cadeiras com percussão corporal. }\end{array}$ & $1 \mathrm{~h} 30 \mathrm{~min}$ \\
\hline $22 / 10 / 13$ & $\begin{array}{l}\text { Aula de percussão corporal com "pergunta e resposta", percussão com as } \\
\text { partes do corpo, batuque da música "Caranguejo não é peixe”, solfejo da } \\
\text { percussão corporal: "tum tum Tum Tum Tum Tum tcha tcha...", aula de } \\
\text { violão com uma música gospel. }\end{array}$ & 02:00 \\
\hline $25 / 10 / 13$ & Aula percussão corporal com alongamentos do corpo e solfejo da percussão, & 1h40min \\
\hline
\end{tabular}




\begin{tabular}{|c|l|c|}
\hline & $\begin{array}{l}\text { roda de percussão com instrumentos violino, violoncelo e violão com a } \\
\text { música “Caranguejo não é peixe". }\end{array}$ & $\begin{array}{c}1 \mathrm{~h} 40 \mathrm{~min}+ \\
1 \mathrm{~h} 20 \mathrm{~min}\end{array}$ \\
\hline $12 / 11 / 13$ & $\begin{array}{l}\text { Aula percussão corporal, com aquecimento do corpo, "pergunta e } \\
\text { resposta"/Bordado para os pais }\end{array}$ & $1 \mathrm{~h} 40 \mathrm{~min}$ \\
\hline $19 / 11 / 13$ & Aula percussão corporal com a roda & $1 \mathrm{~h} 40 \mathrm{~min}$ \\
\hline $26 / 11 / 13$ & $\begin{array}{l}\text { Aula de percussão corporal, técnica barbatuques / Filmagem de alguns } \\
\text { trechos da aula. }\end{array}$ & $2 \mathrm{~h}$ \\
\hline $29 / 11 / 13$ & $\begin{array}{l}\text { Apresentação artística dos alunos dos multiplicadores do IB no } \\
\text { C.E.F.113/Rec. Emas, com a apresentação de um grupo de violões, com a } \\
\text { música "Pais e Filhos" - Legião Urbana. }\end{array}$ & $3 \mathrm{~h}$ \\
\hline $07 / 12 / 13$ & $\begin{array}{l}\text { Sarau. Apresentação musical de todos os alunos do IB, percussão corporal e } \\
\text { instrumentos de orquestra. }\end{array}$ \\
\hline
\end{tabular}

Fonte: Anotações do Caderno de Campo

Nas atividades de música do IB, eram frequentes as rodas de percussão corporal em que se percebia a alegria dos alunos por estarem naquele local aprendendo. Nessas rodas, os multiplicadores aprendem a serem líderes e se tornam responsáveis pelo ensino e aprendizagem de iniciantes. Os multiplicadores representam a autonomia e a sustentabilidade do projeto e possibilitam a continuidade das práticas musicais, especialmente a percussão corporal.

Os dados das observações foram transcritos em um caderno de campo. Todas as aulas foram registradas para que nenhum fato fosse esquecido, pois com o passar do tempo, os registros não escritos se perdem e se torna difícil relembrar os detalhes da observação em campo (COHEN; MANION, 1997, p. 112). O trabalho de campo foi fundamental para descrever e compreender as práticas musicais no IB e a atuação dos multiplicadores.

\subsubsection{As entrevistas}

Ao selecionar como unidade de caso os multiplicadores do IB, para que fosse compreendida a atuação dos multiplicadores naquele Instituto, foi fundamental o contato direto com todos os membros do projeto que atuavam nas aulas de música. Esse contato, como já mencionado, aconteceu de forma participante, segundo orientação de André (2000, p. 37). Ela afirma que o pesquisador, "através basicamente da observação participante [...] vai procurar entender essa cultura”, ou seja, a cultura local, onde estão os atores da pesquisa. Assim, nesta pesquisa, a atuação dos multiplicadores do Instituto Batucar envolve todo o projeto de sustentabilidade do IB e a equipe do Instituto. Todos eles participantes da pesquisa.

Como parte da coleta de dados e para compreender o contexto de atuação dos multiplicadores, realizei entrevistas iniciais com o coordenador do IB, a coordenadora pedagógica, o administrador do IB, uma pedagoga e um "educador" de música, os três 
últimos ex-alunos e multiplicadores no próprio IB. Nesse momento, utilizei a entrevista individual a fim de conhecer e aprofundar as informações sobre o Instituto, sua origem, organização, objetivos, práticas musicais e projeto multiplicadores. Também foi necessária uma entrevista focal com os 12 multiplicadores-alunos do IB, para conhecer como percebiam a sua atuação. Todas as entrevistas individuais foram gravadas com a permissão de todos os participantes. Sobre esse assunto Bauer e Gaskell (2011) afirmam:

\footnotetext{
A entrevista individual ou de profundidade é uma conversação que dura normalmente entre uma hora e uma hora e meia. Antes da entrevista, o pesquisador terá preparado um tópico guia, cobrindo os temas centrais e os problemas da pesquisa. A entrevista começa com alguns comentários introdutórios sobre a pesquisa, uma palavra de agradecimento ao entrevistado por ter concordado em falar, e um pedido para gravar a sessão (BAUER; GASKELL, 2011, p. 82).
}

As recomendações de Bauer e Gaskell (2011) foram observadas, mas as entrevistas individuais tiveram uma duração aproximada de vinte e nove minutos a duas horas e dez minutos, conforme o Quadro 2. Elas aconteceram no próprio Instituto, assim como as entrevistas focais com os multiplicadores, que tiveram duração de trinta e sete minutos a uma hora e dezessete minutos. Foram entrevistados dois grupos, de quatro a oito participantes cada, em dias diferentes conforme o Quadro 3.

As entrevistas individuais foram agendadas com a coordenadora pedagógica, de acordo com a disponibilidade dos participantes, sem prejudicar o andamento das atividades realizadas no IB. As entrevistas de grupo focal com os multiplicadores também foram agendadas e os participantes, menores de dezoito anos, foram autorizados pelos pais a participar. Elas, duas ao todo, ocorreram no IB, no horário em que os alunos são atendidos. Os participantes sentiram-se à vontade para falar e se mostravam muito felizes ao relatar sua vivência no Instituto, o que transparecia em seus rostos. Muito entusiasmados, falaram com muito amor, respeito e admiração por pertencerem ao IB.

Todas as entrevistas totalizaram nove horas e trinta e um minutos de duração e foram transcritas literalmente e organizadas em um caderno de entrevistas. Abaixo, nos Quadros 3 e 4, está a relação de entrevistas com seus participantes e o tempo de cada uma. 
Quadro 3 - Datas, participantes e duração das entrevistas

\begin{tabular}{|c|l|c|}
\hline DATAS ENTREVISTAS/IB & PARTICIPANTES/DURAÇÃO & OTAL DE 7h67min66s \\
\hline $04 / 06 / 13$ & Coordenador & $1 \mathrm{~h} 53 \mathrm{~min}$ \\
\hline $13 / 06 / 13$ & Coordenador & $2 \mathrm{~h} 10 \mathrm{~min} 33 \mathrm{~s}$ \\
\hline $19 / 06 / 13$ & Coordenadora pedagógica & $2 \mathrm{~h} 10 \mathrm{~min} 33 \mathrm{~s}$ \\
\hline $21 / 06 / 13$ & Administrador & $58 \mathrm{~min}$ \\
\hline $27 / 06 / 13$ & "Professor" de música & $1 \mathrm{~h} 36 \mathrm{~min} 58 \mathrm{~s}$ \\
\hline $09 / 07 / 13$ & Pedagoga & $29 \mathrm{~h} 36 \mathrm{~min}$ \\
\hline
\end{tabular}

Fonte: Anotações Diário de Campo

O quadro abaixo mostra os dois grupos focais com os entrevistados e a duração de cada entrevista. A entrevista filmada foi transcrita literalmente para a análise dos dados.

Quadro 4-Datas, participantes e duração dos Grupos Focais:

\begin{tabular}{|c|l|c|}
\hline ENTREVISTAS & PARTICIPANTES & DURAÇÃO TOTAL 1h54min26s \\
\hline $27 / 11 / 13$ & GRUPO FOCAL 1 & $1 \mathrm{~h} 17 \mathrm{~min} 54 \mathrm{~s}$ \\
\hline $28 / 11 / 13$ & GRUPO FOCAL 2 & $37 \mathrm{~min} 26 \mathrm{~s}$ \\
\hline
\end{tabular}

Fonte: Anotações do Diário de Campo

As entrevistas de grupo focal com os multiplicadores foram interessantes e relevantes para a pesquisa. No dia marcado para a primeira entrevista, cheguei ao Instituto por volta de 15h30min. Na tenda, o "educador" de música estava com quatro adolescentes, treinando e tocando no violão algumas músicas sertanejas. Os multiplicadores e uma professora estavam com grupos de alunos em salas específicas e a educadora pedagoga Giselle estava administrando o tempo das aulas, enquanto passava nas salas onde os multiplicadores estavam atuando. Ao chegar ao IB, fui recebida pela pedagoga e esperei que os multiplicadores terminassem a aula para começarmos a entrevista.

Três minutos antes do início da entrevista de grupo focal, organizei juntamente com os multiplicadores as cadeiras em um semicírculo, para que todos os alunos pudessem se olhar e coloquei minha cadeira à frente. Eu me apresentei novamente para todos e expliquei como seria a entrevista, o porquê dela e como se desenvolveria todo o seu processo. $\mathrm{Na}$ entrevista, os multiplicadores ficaram bem à vontade, alguns mais tímidos, outros mais extrovertidos. Durante a entrevista, alegraram-se ao falar e ao dar exemplos de percussão corporal. Ao referir-se aos "professores", falavam com carinho e respeito. Quanto à aprendizagem no IB, a maioria considera o local como um laboratório de aprendizagem, tanto para os alunos como para os multiplicadores. A entrevista focal foi filmada para registro das expressões e exemplos de percussão corporal. 
A primeira entrevista contou com 08 multiplicadores, mas iniciou-se com 07. Um deles chegou atrasado, pegou uma cadeira, se sentou e contribuiu com a entrevista. Durante toda a entrevista os multiplicadores, de um modo geral, estavam alegres, riram muito, estavam bastantes extrovertidos e deram exemplos de percussão corporal, ao falar em batucar.

No início, perguntei o nome de cada um dos multiplicadores e há quanto tempo estavam no Instituto. A primeira parte do vídeo durou dezessete minutos e cinquenta e quatro segundos, quando Giselle me falou que a filmagem havia parado. Fui verificar e, como estava tudo normal, coloquei para filmar novamente e a segunda parte durou cerca de uma hora. No final da entrevista agradeci a participação de todos. Eles sorriram e aplaudiram. Pareciam ter aprendido e conhecido mais uns aos outros durante a entrevista. Mostraram-se bastante entusiasmados e bem confortáveis durante toda a nossa conversa. A entrevista durou uma hora, dezessete minutos e cinquenta e quatro segundos. Foi entregue aos participantes uma carta de concessão de imagem e áudio. Durante toda a entrevista, o educador musical André ficou observando a atividade.

A segunda entrevista se desenvolveu de forma semelhante e ocorreu no dia 28 de novembro de 2013. Ao chegar ao Instituto, encontrei o educador André e mais dois multiplicadores vendo seu próprio vídeo no YouTube. Para essa entrevista, a pedagoga Giselle juntou 04 multiplicadores e os organizou. Enquanto isso acontecia, eu coloquei o aparelho para a filmagem na janela, fixo, para que o filme não saísse com movimentos. Como na primeira entrevista, perguntei, para iniciar, o nome dos multiplicadores e o tempo de cada um no instituto. A entrevista durou trinta e sete minutos e vinte e seis segundos. De forma semelhante à outra turma, foi entregue aos participantes uma carta de concessão de imagem e áudio. Durante toda a entrevista o André ficou observando. Tanto as entrevistas individuais como as entrevistas de grupo focal foram transcritas. Foi criado um caderno com todas as transcrições das entrevistas e as falas dos participantes foram interpretadas e analisadas.

\subsection{PROCEDIMENTOS DE ORGANIZAÇÃO E ANÁLISE DE DADOS}

Para que a análise dos dados aconteça, Bogdan e Biklen (1994) afirmam que eles devem refletir as perspectivas, vivências, concepções, crenças e opiniões dos entrevistados:

Os dados recolhidos são designados por qualitativos, o que significa ricos em pormenores descritivos relativamente a pessoas, locais e conversas, e de complexo tratamento estatístico. As questões a investigar não se estabelecem mediante a operacionalização de variáveis, sendo, outrossim, formuladas com o objetivo de investigar os fenômenos em toda a sua complexidade e em contexto natural. Ainda 
que os indivíduos que fazem investigação qualitativa possam vir a seleccionar questões específicas à medida que recolhem os dados, a abordagem à investigação não é feita com o objetivo de responder a questões prévias ou de testar hipóteses. Privilegiam, essencialmente, a compreensão dos comportamentos a partir da perspectiva dos sujeitos da investigação (BOGDAN; BIKLEN, 1994, p. 16).

Todas as falas das entrevistas, transcritas literalmente, organizadas em cadernos, foram analisadas à "exaustão" e separadas por categorias. As categorias permitem ao pesquisador identificar ideias, pensamentos, concepções e visão de mundo dos participantes da pesquisa e assim responder aos seus objetivos. Sobre as categorias das entrevistas, Moroz e Gianfaldoni (2006) destacam o processo de exaustão das categorias e o rigor metodológico. Eles afirmam que:

\footnotetext{
Vale lembrar que as boas categorias devem apresentar como qualidades: a) a exaustão: deve permitir a inclusão de todos os dados coletados relativos a um determinado tema; b) a exclusão mútua: deve permitir que cada dado seja classificado em apenas uma categoria; c) a objetividade: as diferentes partes do material devem ser codificados do mesmo modo, ainda que submetidas a análises em momentos - ou por pesquisadores - diferentes, significando que além de ter uma boa definição, a categoria deve tornar precisos os índices que determinam a inclusão de cada elemento (MOROZ; GIANFALDONI, 2006, p. 87-88).
}

As entrevistas foram organizadas em um caderno, contendo os roteiros e as transcrições das entrevistas conforme a seguinte ordem: 1) roteiro do coordenador e em seguida sua entrevista; 2) roteiro da coordenadora pedagógica e em seguida sua entrevista; 3 ) roteiro do administrador do projeto e em seguida sua entrevista; 4) roteiro do "professor" de música e em seguida sua entrevista; 5) roteiro da pedagoga e em seguida sua entrevista; 6) roteiro dos multiplicadores, do grupo 1 e em seguida sua entrevista e 7) roteiro dos multiplicadores do grupo 2 (o mesmo do grupo 1) e em seguida suas entrevistas transcritas. $\mathrm{O}$ caderno foi numerado a partir de dados como o local da entrevista, a data, a duração, o nome do participante seguido do roteiro e das transcrições o que gerou um único volume de 193 páginas.

As falas dos participantes foram organizadas por códigos, siglas, apresentadas como códigos para que fossem organizadas a fim de que a análise das falas no processo de categorização fosse realizada. São elas: (C.R.,p.) Coordenador Ricardo, página; (C.P.P., p.) Coordenadora Pedagógica Patrícia, página; (A.A., p.) Administrador Alceu, página; (P.M.A, p.) "Professor" de Música André, página; (P.G., p.) Pedagoga Giselle, página; (M.L.,p.) Multiplicador Leonardo, página. Nesta dissertação foi utilizado os nomes reais dos educadores do IB (Ricardo, Patrícia, Alceu, André e Giselle) e nomes fíctícios dos 
multiplicadores para preservar sua identidade, pois são menores. Seus nomes fictícios nesta dissertação são: Luciana, Paulo, Milena, Leonardo, Vânia, Émile, Raíssa, Ana e Roseli. Nas falas tanto dos educadores como dos multiplicadores, foi necessário fazer uma intervenção com o colchete [ ] em alguns casos com o acréscimo de palavras, sem comprometer a informação, para esclarecer melhor as falas para o leitor.

Em uma primeira categorização, destacamos as seguintes categorias, organizadas em duas grandes categorias: 1) Instituto Batucar e 2) Multiplicadores. Com relação ao Instituto Batucar, foram relacionadas as seguintes subcategorias: instituição, estrutura e organização, princípios pedagógicos, objetivos, autoestima, práticas musicais, aulas de música. $\mathrm{Na}$ categoria Multiplicadores, observamos as seguintes subcategorias: formação, concepções, desafios.

No IB, especificamente, ao apresentar as categorias resultantes da coleta de dados, percebe-se que elas refletem as situações de aulas constatadas durante as observações e por meio das falas dos participantes nas entrevistas. As categorias passam por um processo de redução até que se tenham alcançando expressões e termos que expressem a percepção dos multiplicadores sobre seu processo de tornarem-se educadores. As categorias emergiram das entrevistas, realizadas individualmente com os participantes do IB e com grupo focal, no caso, com os multiplicadores.

A partir do caderno de entrevistas foi feito um caderno de redução de dados das falas dos participantes, contendo 65 páginas, onde foram registradas falas organizadas por categorias, que foram numeradas e encontradas através das falas dos participantes, o que permitiu encontrar as categorias. Foram feitas várias releituras das falas dos participantes e as categorias surgiram com os temas mais fortes encontrados nas entrevistas.

\subsection{CRITÉRIOS ÉTICOS DA PESQUISA}

A organização dos dados coletados numa pesquisa passa primeiramente por uma análise, seguida de um processo de leitura e releitura, passando assim para a fase de teorização, como explicam Ludke e André (1986). Segundo as autoras, o pesquisador deve se ater não somente à análise das descrições encontradas, mas ir mais além, saltar adiante, procurar novos esclarecimentos e conceitos. E, a partir desse pressuposto, questões éticas devem ser preservadas, como a ética envolvida entre pesquisador e as pessoas do campo pesquisado, o sigilo das informações conhecidas pelo pesquisador, o problema da 
subjetividade do pesquisador, no caso de sua interferência na coleta de dados e a fidedignidade ligada ao que foi dito anteriormente.

A permissão para a pesquisa no campo, no IB, ocorreu por meio de um primeiro contato com os participantes do projeto seguido de uma carta de concessão, que foi entregue ao coordenador do projeto. Assim ocorreu também com as entrevistas: cada entrevistado recebeu uma carta permitindo a gravação do áudio e a sua transcrição. O mesmo ocorreu com os multiplicadores: a carta foi enviada para seus pais assinarem, por serem menores de 18 anos, permitindo a gravação da entrevista em áudio e vídeo. Uma carta também foi feita para as observações realizadas nas aulas dos multiplicadores no Centro de Ensino Fundamental 113 - Recanto das Emas (C.E.F.113/Rec. Emas). Dois momentos foram filmados: uma aula de violão e uma apresentação artística. Os alunos também receberam as cartas para a permissão dos pais.

Nesta pesquisa, portanto, as entrevistas permitiram um conhecimento mais profundo das ideias, das concepções de atuação dos multiplicadores no projeto, assim como as suas práticas pedagógicas musicais. É importante destacar que os participantes respeitam os alunos, admiram os professores, sentem-se privilegiados em estar nesse espaço de aprendizagem considerado por todos como um laboratório de aprendizagem, onde os multiplicadores se apropriam do espaço e aprendem também a ensinar música na sua prática cotidiana. 


\section{O INSTITUTO BATUCAR}

Este capítulo apresenta o Instituto Batucar (IB), a sua localidade, o perfil da comunidade atendida pelo Instituto, os recursos utilizados pelo projeto para obter a sustentabilidade e as parcerias que o auxiliam. A estrutura e organização são apresentadas para o conhecimento das estruturas administrativas e pedagógicas. Os princípios pedagógicos mostram como o Instituto prioriza a cidadania e a transformação social dos atendidos por meio da música, estreitando a distância entre a música e o ser humano. O aprender a ensinar se dá por meio da observação, da imitação, da escuta e das orientações dos educadores, ou seja, a partir das experiências no IB na própria oficina de música.

\subsection{A INSTITUIÇÃO: A MÚSICA NO CORPO PARA TRANSFORMAR}

O Instituto Batucar se localiza no Recanto das Emas, XV Região Administrativa (XV RA) do Distrito Federal. A região tem uma população estimada de 110.462 habitantes, com um número de domicílios de aproximadamente 29.552 residências e um índice de vulnerabilidade de 54,4\%, segundo os dados pesquisados em 2010 pelo Departamento Intersindical de Estatística e Estudos Sócioeconômicos (DIEESE) ${ }^{10}$. São considerados fatores de vulnerabilidade: famílias que residem em domicílio de infraestrutura inadequada; famílias que possuem uma renda per capita inferior a um quarto de salário mínimo; mulheres que são chefe de casa, analfabetas e responsáveis pelo sustento da família com crianças de 0 a 14 anos; famílias com pessoas com 16 anos ou mais desempregados ou à procura de emprego; família com pessoas de 10 a 15 anos que trabalham; família com renda per capta inferior a meio salário mínimo e família com indivíduo portador de deficiência física ou mental. Segundo os resultados da pesquisa do DIEESE, em 2010, o Recanto das Emas apresentava um perfil populacional predominantemente de mulheres, negros e crianças e adolescentes na faixa de 6 a 15 anos, conforme os dados abaixo:

No Recanto das Emas, há $48 \%$ de homens e $52 \%$ de mulheres. Os negros são a maioria da população, representando $66 \%$ do total de habitantes. Em relação à faixa etária, há $4 \%$ de crianças com até 3 anos e $7 \%$ de crianças entre 3 e 6 anos. Crianças e adolescentes entre 6 e 15 anos são $18 \%$ dos habitantes da RA; jovens de 15 a 17 anos são de $9 \%$. Pessoas com 60 anos ou mais são $4 \%$ da população de Recanto das Emas. Quanto à posição que ocupam no domicílio, 44\% dos habitantes são "fillhos";

\footnotetext{
${ }^{10}$ Disponível em:

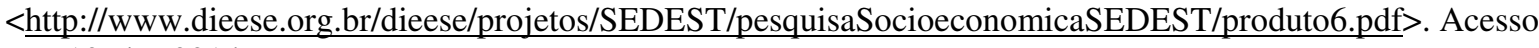
em: 10 abr. 2014
} 
$28 \%$ chefes; e 20\% cônjuges (Disponível em: <http://www.dieese.org.br/dieese/projetos/SEDEST/pesquisaSocioeconomicaSEDE ST/produto6.pdf>. Acesso em: 10 abr. 2014).

A pesquisa revela ainda que a maioria da população é de filhos, o que demanda um cuidado socioeducativo e justifica a presença de projetos sociais na comunidade. Nesse contexto, o IB atende somente crianças, adolescentes e jovens moradores do Recanto das Emas, pré-requisito para participar das atividades.

O projeto teve suas atividades iniciadas em 2001, quando o professor de música Ricardo Amorim, idealizador e coordenador atual do IB, foi convidado para dar aulas de música na Igreja Presbiteriana local. Na época, Ricardo Amorim era estudante do curso de Licenciatura em Educação Artística - Música da Universidade de Brasília. Segundo ele, a ausência de instrumentos musicais estimulou o desenvolvimento de um trabalho de música com o corpo: a percussão corporal. O trabalho musical iniciou-se a partir de um diálogo com o público interessado e após uma demonstração de percussão corporal.

\footnotetext{
O Batucar começou [...], nasceu em 2001 quando eu fui convidado pela igreja presbiteriana de Brasília pra fazer um trabalho [...] com a equipe de louvor da igreja [...] ela é uma congregação aqui, [...] da igreja presbiteriana no Recanto das Emas, [...] então quando eu cheguei. A ideia era trabalhar com prática de conjunto é, que seria formação de baixo, bateria, violão, guitarra, teclado e voz voltado para o louvor da igreja, porém a gente encontrou [...] apenas uma bateria e um violãozinho [...] pra 12 jovens que eram os meninos que compunham essa equipe de louvor... (Entrevistas, RICARDO, p. 03).
}

Hoje, o IB cresceu e desenvolve suas atividades em uma residência situada na Quadra 307 no Recanto das Emas. De acordo com informações do site da instituição, o IB é uma OSCIP voltada para a inclusão social ${ }^{11}$.

No IB são atendidas, atualmente, cerca de 100 crianças. As atividades são organizadas por grupos e ocorrem durante a semana na forma de aulas, ensaios, organização do espaço e materiais, acompanhamento pedagógico, performance, orquestra e reuniões pedagógicas realizadas depois das atividades de música.

Em busca da sustentabilidade, o IB conta com alguns apoios financeiros e apoios técnicos. Os apoios financeiros consistem em doações de pessoas físicas ou jurídicas que contribuem mensalmente para o projeto, o que gera a sustentabilidade das atividades do

\footnotetext{
${ }^{11}$ BATUCAR, Acesso em: 21 mar. 2013. Disponível <http://www.institutobatucar.org.br/005/00502001.asp?ttCD_CHAVE=14935)>.
} 
Instituto. Alguns dos patrocinadores são a Igreja Presbiteriana de Brasília (IPBsb); o Ofício Digital; a Gazeta Jurídica; o Colégio Reação; o Corpo 4 Academia; e o Zinc. ${ }^{12}$

Os apoios técnicos também consistem em doações de materiais e serviços por pessoas físicas ou jurídicas, como a Itaú Unicef; o Rumos Itaú Cultura; a Fundação Itaú Social; o Centro de Apoio de Desenvolvimento Tecnológico - UnB (CDT-UnB); a $2^{\circ}$ Igreja Presbiteriana do Recanto das Emas; o Centro de Estudos Pesquisas Educação e Cultura (Cenpec); a Incubadora de Arte e Cultura; o Núcleo Barbatuques e a Sociedade Bíblica do Brasil.

Além das parcerias, o Instituto Batucar desenvolve o "projeto multiplicadores" que consiste em incentivar, apoiar e formar crianças e jovens do Instituto em facilitadores e monitores, para replicar a metodologia utilizada e os princípios pedagógico-musicais das aulas de percussão corporal. Os multiplicadores, ao longo de sua trajetória no projeto, participaram, juntamente com os membros do Instituto, de eventos voltados para projetos sociais, são eles: o Prêmio Itaú Unicef (2011), semifinalista; o Rumos Itaú Cultural (2011); o Prêmio Anu (2010); o Prêmio Itaú Unicef (2009) e o Rumos Itaú Cultural (2008).

O projeto busca obter meios para a sua sustentabilidade através de projetos internos, como o projeto "multiplicadores", e projetos externos que consistem em participações em editais promovidos por empresas e órgãos oficiais. A sustentabilidade do IB promove a continuidade das atividades desenvolvidas no Instituto, que preza pela formação cidadã dos alunos da região do Recanto das Emas. A busca pela sustentabilidade do projeto é uma preocupação constante do administrador do IB, ex-aluno e multiplicador, Alceu Avelar, que considera um desafio a captação de recursos para que as atividades não terminem. Ele afirma :

[...] meu desafio como administrador [...] é ter recursos aqui pra que isso não feixe, [e] essas crianças não fiquem a mercê aí, afora (Entrevistas, ALCEU, p. 107).

O IB já participou de vários editais e já teve muitas parcerias, mas percebeu que os editais de apenas um ano mantêm um educador de música no IB, mas o tempo de permanência desse educador não permite a continuidade dos trabalhos desenvolvidos.

Alceu Avelar reconhece a necessidade de o projeto ser autossustentável e vê isso como um desafio, em suas palavras:

\footnotetext{
${ }^{12}$ ZINC: Loja de acessórios localiza na Asa Sul, na Asa Norte e no Sudoeste (Brasília -DF).
} 
[...] ter sua própria sustentabilidade é não depender de ninguém [para] que a gente possa ser sustentável, esse é meu desafio aqui: a sustentabilidade do Instituto [...] (Entrevistas, ALCEU, p. 108).

Os multiplicadores são parte desse trabalho de sustentabilidade e desenvolvem um papel muito importante no IB, colaborando para a sua continuidade e autonomia, especificamente no que diz respeito ao ensino de música. Eles contribuem para que não faltem educadores no projeto e para que o próprio IB possa se autossustentar.

\subsubsection{Estrutura e Organização}

A estrutura organizacional e física do IB constitui-se da parte administrativa e da parte pedagógica. Alceu Avelar é o administrador do IB e o responsável por toda a parte administrativa. Como já dito, ele começou no IB como aluno, foi multiplicador (monitor), foi educador e hoje é administrador formado. Algumas vezes, quando o IB precisa, ele também exerce a função de educador. É responsável pela manutenção do projeto, pelas questões financeiras, administração de documentos e pessoal, como contratação de professores, participações em editais e eventos socioculturais, enfim, toda a parte que envolve a organização, manutenção e administração do IB. Assim, ele afirma que:

[...] é eu que contrato é eu que vejo [o] que precisa, eu que faço o orçamento.[Eu] tenho que ir atrás pra ver o que a gente pode mudar [...] questão administrativa, dos projetos [...] eu vínculo com o contador a questão das declarações das certidões, questão [...] aqui de fluxo aqui dentro do Instituto, de manutenção de contratação de pessoal pra manutenção do Instituto e [de] alguns recursos [...] pra contratar professor. Tem a seleção, a gente vai fazendo um processo de seleção vai conversando [...] Agora a última que a gente tá se dedicando um pouco mais que é a captação de recurso [...] Aí entra nessa área [...] a gente tá estudando pra captar recursos fora dos editais [...] Que seria visitação nas empresas, [...] com pessoas físicas [que] apoiam o projeto, criam um vínculo pra que os recursos possam vir [para] o Instituto [...] e sustentar essa estrutura que nós já temos hoje [...] (Entrevistas, ALCEU, p. 101).

O administrador faz um trabalho muito importante no IB. Como o trabalho é compartilhado, o administrador é o responsável por cuidar da parte administrativa e os educadores não precisam se preocupar com essas questões. Os educadores são responsáveis somente pelas aulas, pelo planejamento e pelas reuniões pedagógicas. O que não acontecia nos projetos sociais em que atuei como educadora, pelo contrário, os projetos tinham muitas questões administrativas para resolver e estas eram atribuídas aos educadores, por não haver uma pessoa específica para tratar desses assuntos. Então, organizar passeios, ligar para empresas, arrumar salas para dar aulas eram algumas atribuições confiadas aos educadores. 
A estrutura pedagógica do IB constitui-se, assim, de um coordenador e professor de música, Ricardo Amorim, uma coordenadora pedagógica, Patrícia Amorim, uma pedagoga Giselle Luiza, um educador de música, André Soares e doze multiplicadores. Como já mencionado, os multiplicadores são os alunos que frequentam o IB e começam a ajudar os professores nas aulas, sendo monitores. As atividades de música acontecem nas salas da casa sede e em uma tenda armada em espaço aberto, onde são realizadas aulas, reuniões de pais e apresentações de saraus.

Os participantes do projeto frequentam as atividades ou oficinas três vezes por semana, como já mencionado, durante três horas e quarenta minutos, quando têm aulas de percussão corporal, violão e prática de orquestra. Esta última ocorre uma vez por semana e é desenvolvida sob a orientação de maestro da Escola de Música de Brasília. Logo após as aulas, são realizadas reuniões pedagógicas com toda a equipe, incluindo os multiplicadores, a fim de se discutirem e compartilharem orientações para o desenvolvimento das aulas e sua avaliação.

O projeto oferece as seguintes atividades pedagógico-musicais: aulas de Percussão Corporal; aulas de violão; Prática de Orquestra com aulas de violinos, violoncelo e violão. $\mathrm{O}$ IB tem ampliado sua oferta de ensino e aprendizagem de instrumentos musicais para o desenvolvimento musical dos alunos e eles têm liberdade de aprender os instrumentos disponíveis que quiserem, como afirma a multiplicadora Luciana:

Eu entrei assim de penetra, então meu primo o Alexandre, [...] me chamou aqui. [Ele] que me ensinou o baião. [...] Eu comecei [e] treinei mais coisas assim. Peguei o violão[...] depois o violino, [agora estou no] contrabaixo [...] (Entrevistas, LUCIANA, p. 185).

Na prática da percussão corporal e de instrumentos, o IB cumpre com seus objetivos de formar cidadãos responsáveis e comprometidos com a comunidade. No projeto, vivenciase o desenvolvimento do ser humano por meio da música. Isso é constatado por meio do encontro entre o ensino musical e o ensino dos valores humanos que envolvem também a participação das famílias dos alunos. Para isso, o Instituto promove saraus, quando os alunos apresentam músicas arranjadas com a percussão corporal. Além disso, eles se apresentam em escolas, igrejas, faculdades e empresas. Nesses momentos as famílias também participam e valorizam o trabalho das crianças e jovens.

Os alunos do Instituto Batucar são moradores de baixa renda do Recanto das Emas. Alguns não moram com os pais, moram com responsáveis, membros da família ou amigos. 
Alguns frequentam a Igreja Presbiteriana. São 100 alunos, com idade entre 06 e 17 anos, estudantes. Muitos conheceram o Instituto Batucar por meio da Igreja Presbiteriana, ingressaram no Instituto, destacaram-se e passaram a desenvolver um trabalho de multiplicador. Eles estão diariamente no Instituto Batucar auxiliando os educadores no trabalho com a música e participam de reuniões pedagógicas, além de se organizarem uma vez por semana a limpeza do local e a organização dos instrumentos musicais.

\subsection{PRINCÍPIOS PEDAGÓGICO-MUSICAIS: CORPO, VOZ E MOVIMENTO}

Os princípios pedagógico-musicais desenvolvidos pelo IB têm na percussão corporal o fundamento da educação musical e a ponte para a aprendizagem dos outros instrumentos oferecidos pelo Instituto. É por meio da percussão corporal que os alunos aprendem os ritmos, vivenciam a prática de conjunto e a estrutura e organização musical, como ocorre, principalmente, na roda de percussão corporal. Nessa mesma atividade, o canto é inserido, com ou sem instrumento musical.

A proposta pedagógica do IB adota um triângulo pedagógico ${ }^{13}$ que consiste em trabalhar o corpo, a voz e o movimento. Segundo as palavras do coordenador, nas atividades educativo-musicais, esses princípios são priorizados como parte essencial e fundamento do desenvolvimento musical dos alunos:

É outro princípio adotado aqui: [...] tem um triângulo que a gente trabalha como base o corpo, a voz e o movimento, isso como base para o aprendizado e o desenvolvimento musical (Entrevistas, RICARDO, p. 31).

O triângulo citado pelo coordenador do Instituto Batucar é apresentado na Figura 2, em que se identificam os princípios do IB: corpo, voz e movimento.

\footnotetext{
${ }^{13} \mathrm{O}$ triângulo pedagógico é adotado pelo Instituto Batucar nas aulas de percussão corporal como principio pedagógico (Fonte Apostila do Instituto Batucar).
} 


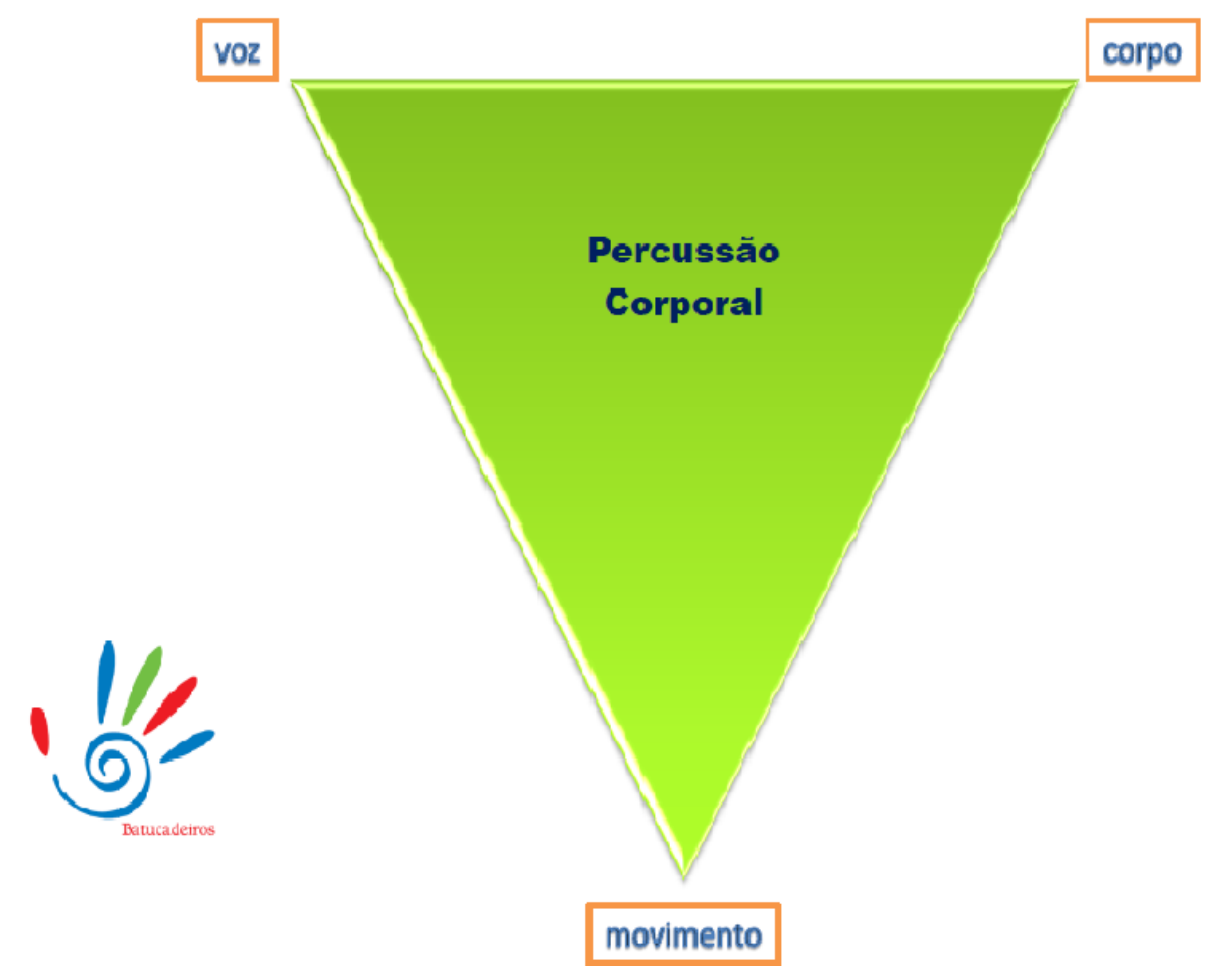

Fonte: Apostila BATUCADEIROS, 2013, p. 08.

Os princípios adotados pelo IB são a base do aprendizado musical conforme destaca o idealizador do projeto, Ricardo Amorim. Isso significa que toda prática de percussão corporal deve envolver o corpo, a voz e o movimento, por meio dos movimentos feitos com os membros do corpo, como os pés, as mãos produzindo sons ao estalar os dedos, ao bater no peito, na perna e a voz que produz sons musicais como o canto. Paralelamente à atividade musical, os alunos são orientados a serem sujeitos de sua história de vida, de sua formação pessoal, profissional e cidadã, em que a mudança social e a transformação da sua realidade são metas educativas.

A aprendizagem no IB é colaborativa: os alunos aprendem juntos e ensinam outros enquanto aprendem. Os multiplicadores auxiliam nesse aprendizado e são estimulados a se tornarem líderes e autônomos. Os exercícios pedagógico-musicais envolvem um aspecto lúdico, como, por exemplo, quando brincadeiras são realizadas ao mesmo tempo em que a música é executada. Então, músicas como "Sapo Cururu”, "Quem te ensinou a nadar", "O sapo não lava o pé”, são cantadas juntamente com a percussão corporal e junto com uma coreografia. A performance é ensinada passo a passo, iniciando com um círculo em que os 
alunos se posicionam e se movimentam, marcando o pulso como instrui o método O Passo ${ }^{14}$, executando sons no corpo e cantando a melodia.

A roda de percussão corporal no IB inicia-se com os educadores e alunos. Todos abrem a roda e dão as mãos para o colega do lado. Em seguida o educador explica como seria o exercício, como por exemplo, escolher um colega com olhar e bater uma palma como se estivesse jogando essa palma para o colega e o colega responde da mesma forma, observando o pulso. Esse exercício é chamado de "flecha" 15 e é realizado juntamente com o Passo. Este pode ser em quatro tempos, quando o pé direito vai para frente em seguida o pé esquerdo, depois o pé direito para trás e em seguida o pé esquerdo. Na sequência, um educador propõe o seguinte exercício: fazer um som ou palavra entoada para um colega e esse colega passa o som ou palavra para outro até o fim da roda. O som e/ou a palavra ficam a critério dos participantes e podem variar entre "oi”, “ei”, “dom”, “ti”, estalo de dedos, por exemplo.

Formação em roda. Inicia-se com alguém lançando uma palma para outra pessoa da roda, projetando o olhar e o direcionamento das mãos no momento da palma. A pessoa que recebe deve direcionar o mesmo som e movimento a um outro participante da roda. Primeiro momento sem pulso podendo evoluir para: com pulso, usando o passo no tempo e no contratempo; com células rítmicas (BATUCADEIROS, 2013, p. 11).

Os exercícios se desenvolvem para motivos rítmicos executados com os timbres do corpo como: "peito, peito", "palma, palma". O "peito, peito" consiste em bater as mãos alternadas, direita e esquerda, no peito, fazendo a percussão corporal e "palma, palma" consiste em bater as duas mãos. A atividade sonoro-corporal é realizada juntamente com o Passo e, com a desenvoltura do movimento, começa-se a cantar uma canção como "Atirei o pau no gato", "Caranguejo não é peixe”. Outros timbres também são explorados com o corpo, como pode ser visualizado na Figura 3:

\footnotetext{
${ }^{14}$ O método de educação musical "O Passo" foi desenvolvido por Lucas Ciavatta em 1996, é utilizado no Brasil e no exterior. Disponível em: http://www.opasso.com.br/ Acesso em 30/09/14.

${ }^{15}$ Atividade desenvolvida pelo grupo Barbatuques. Apostila: Batucadeiros Oficina de Percussão Corporal

Capacitação de Educadores, p. 11.
} 
Figura 03: Música "Caranguejo não é Peixe"
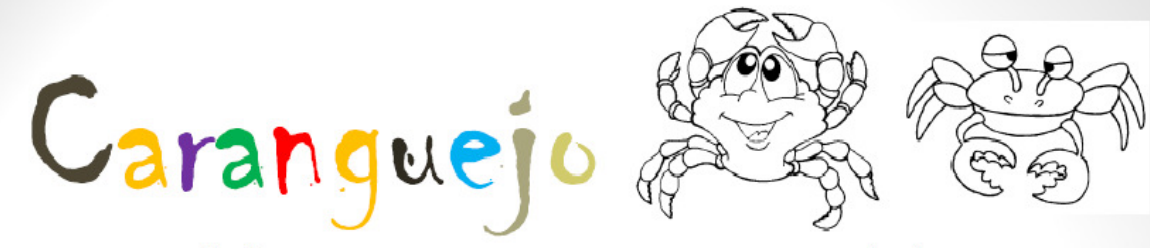

Caranguejo não é peixe Caranguejo peixe é, Caranguejo só é peixe $\mathrm{Na}$ enchente da maré
Tum tum tum tum tum tum txá txá Txá txá txá txá tum tum pá

Dom dom dom dom txi txi bô bô

Txum txum txá txá dom dom pá

Batuque-se!
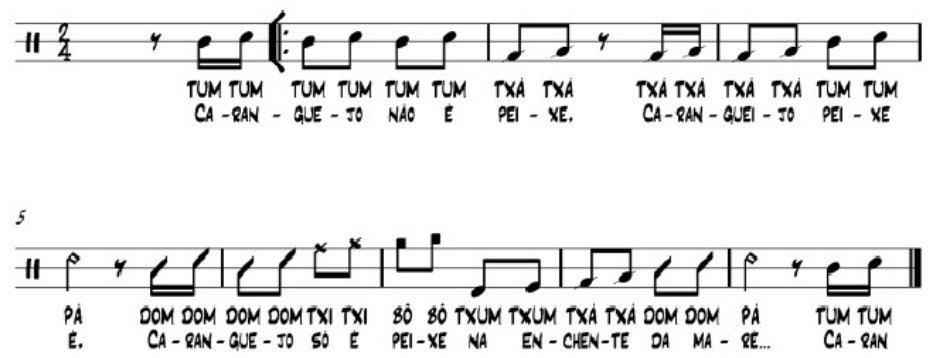

$\begin{array}{llllll}\text { PA DOM DOM DOM DOM TXI TXI } & 80 \text { 8O TXUM TXUM TXA TXA DOM DOM PA } & \text { TUM TUM } \\ \text { E. CA - RAN - GUE - JO SO EE PEI - XE NA EN - CHEN-TE OA MA - QE... } & \text { CA - QAN }\end{array}$

Caranguejo
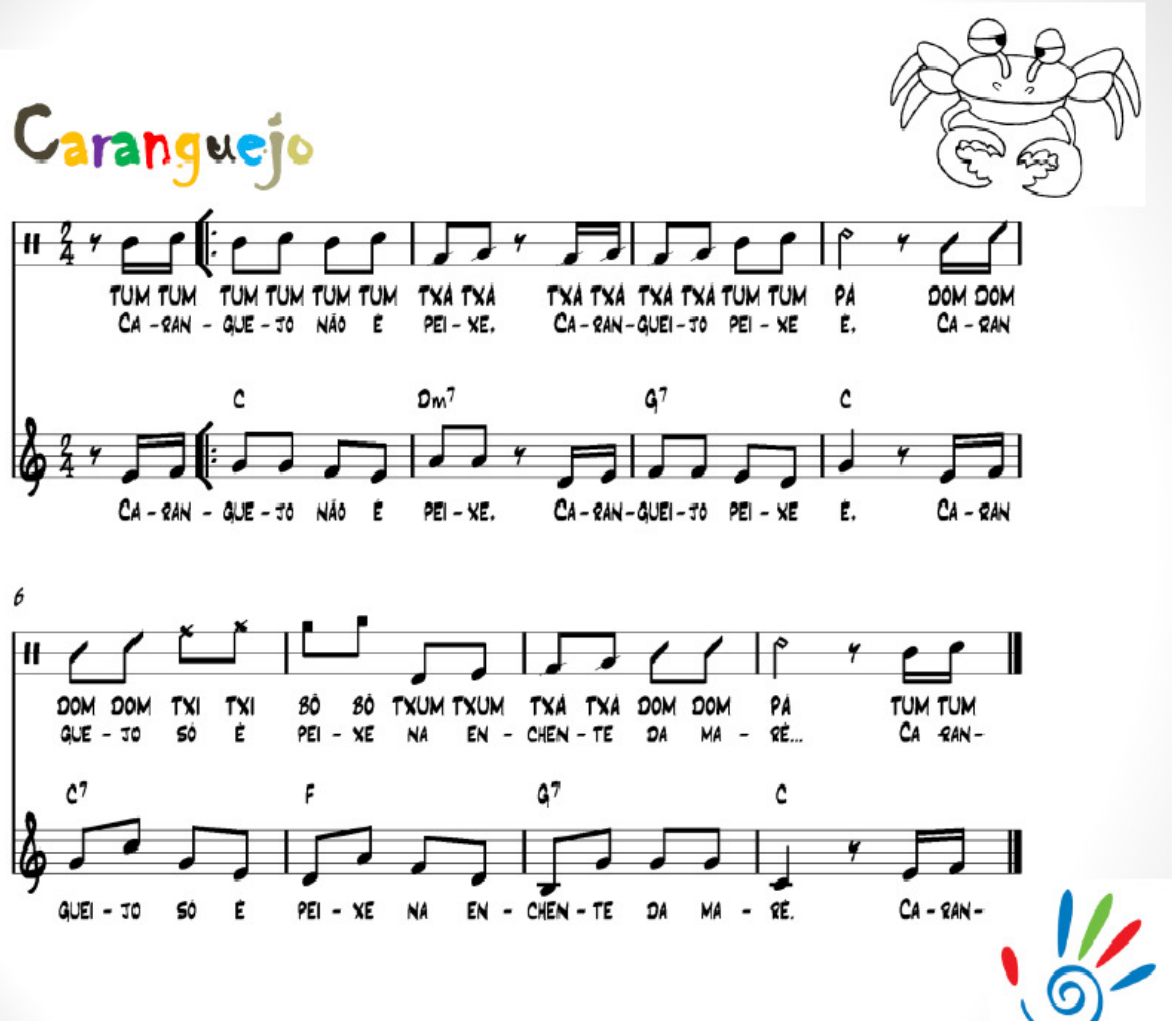

Fonte: BATUCADEIROS, 2013, p.20-21. 
A nomenclatura escrita na partitura anterior em forma de omanotopéias como "Tum, Tum, Bô, Txum, Txá, Dom, Pá” são representações sonoras criadas pelos Batucadeiros para identificar e diferenciar os sons corporais, denominada "solfejo corporal". A nomenclatura utilizada e o som corporal utilizado são apresentados na Figura 4:

Figura 04: Nomeclatura sons básicos

\section{Nomenclatura}

sons básicos

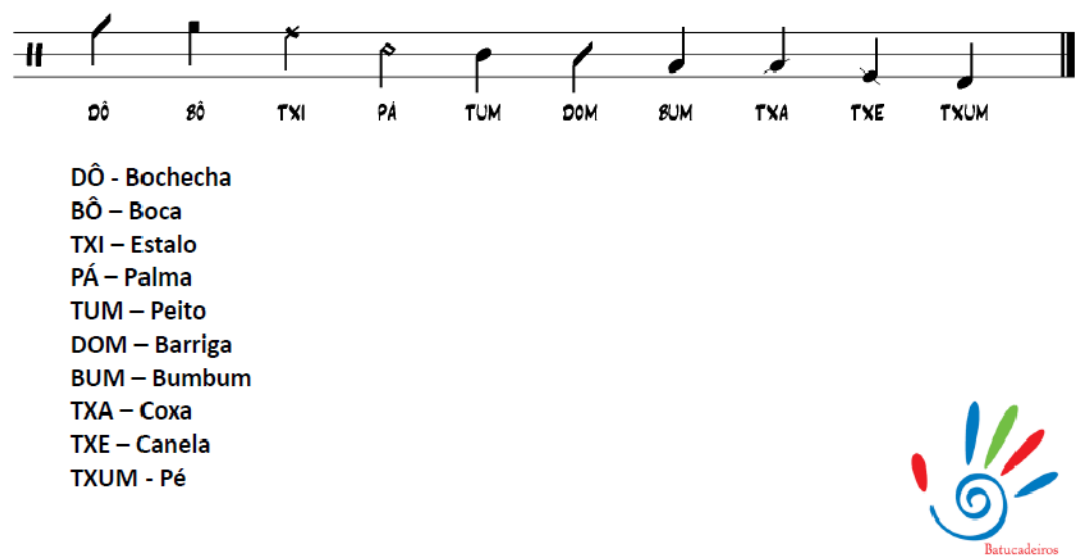

Fonte: BATUCADEIROS, 2013, p. 09.

O movimento, os sons explorados por todos na roda de percussão corporal, os valores humanos como o respeito e a amizade são elementos trabalhados por meio das atividades propostas. Os movimentos da percussão e os exercícios realizados em pares, proporcionam momentos em que se cria um clima de amizade, descontração e respeito pelos colegas. Nas atividades, os educadores orientam a interação e a colaboração, a partir de um clima agradável e feliz. Os educadores trazem em seus semblantes a serenidade e a alegria, o que proporciona um ambiente caloroso e um clima que permite a aproximação entre os alunos. Nessa interação é muito comum ver os alunos ficarem mais um tempo no IB, depois das aulas, para conversar com os educadores, o que gera um sentimento de amizade e de pertencimento ao grupo.

$\mathrm{Na}$ roda, o educador explora a interação com os alunos, possibilitando um contato mais visual e gestual do que oral. Numa das falas do coordenador do Instituto, ele explica como isso acontece: 
A gente trabalha com roda porque a roda eu posso olhar no teu olho, no olho dela e assim a gente tem um contato pessoal, humano, o contato humano bem próximo e esse trabalho da roda é ele também remete o que? A roda da ciranda, que é o princípio lúdico é a gente tenta buscar aqui, [para que] esses princípios sejam realizados no contexto com os alunos, no contexto de um encontro [...] (Entrevistas, Coordenador RICARDO, p. 33).

A roda de percussão corporal detalhada pelo coordenador Ricardo, pode ser visualizada por meio da Foto 05, apresentada abaixo:

Figura 05: Foto-A Roda de Percussão Corporal

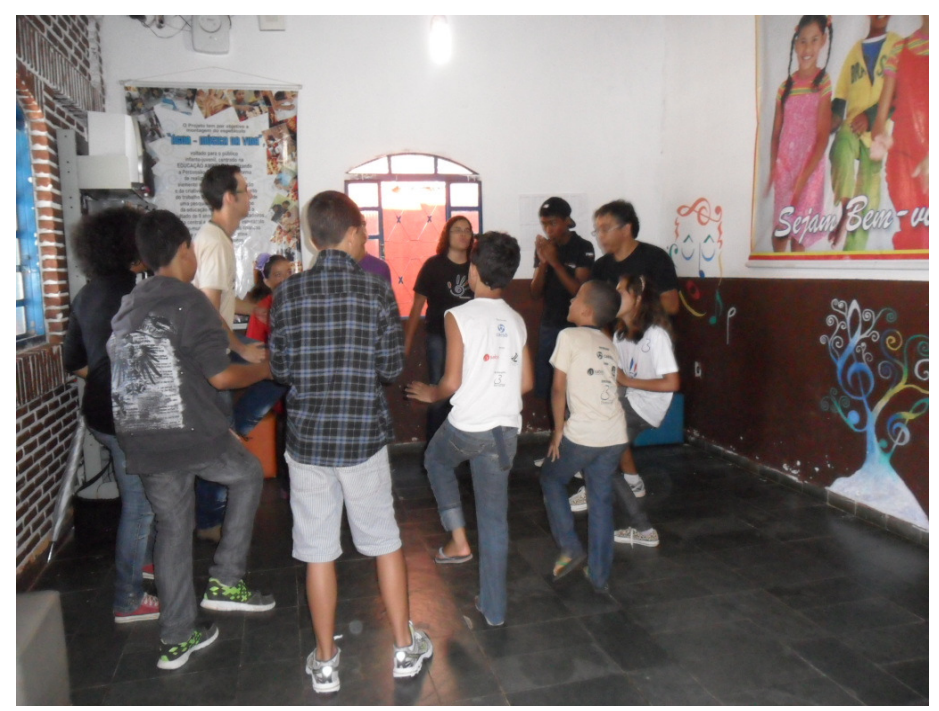

Fonte: foto tirada por mim em novembro de 2013, no Instituto Batucar.

$\mathrm{Na}$ roda de percussão corporal acontece um encontro que considera todas as informações que os alunos trazem, o que o educador André chama de "aula tribal"

[...] isso é aula tribal, a gente pensa que cada informação que cada um traz tem a mesma importância dentro da aula seja ele iniciante, ou seja, ele um que já esteja com a técnica mais apurada (Entrevistas, ANDRÉ, p. 127).

Além da amizade construída no convívio das atividades, o desempenho educacional é considerado importante. A pedagoga Giselle Luiza é responsável pelo acompanhamento pedagógico dos alunos com mais dificuldades escolares. Nesses encontros, os alunos são orientados a organizar sua vida escolar: como organizar os cadernos, como cumprir com as metas de estudo e deixar o dever de casa sempre em dia. Em suas palavras,

[...] trabalhávamos com jogos pedagógicos [...] como xadrez, muitas vezes produção de textos, produção escrita, apresentações com os adolescentes. As crianças viram e quiseram participar. [...] [Faz parte do acompanhamento pedagógico] organizar a parte da escola a parte da visita, parte do acompanhamento com as famílias, [...] 
realmente [...] buscando essa questão da escola de reforço, de dever de casa, de acompanhamento de caderno, de conversa com os pais de acompanhamento escola família e batucadeiros. (Entrevistas, GISELLE, p. 115-116).

O trabalho realizado pela pedagoga Giselle envolve não somente a questão educacional, mas também a orientação às famílias dos alunos do IB. Há um esforço para gerar um diálogo com os pais, aproximando-os da vida escolar dos filhos e do IB. Os alunos são orientados a estudar, a ter futuramente um trabalho e a levar para a vida profissional a responsabilidade e a formação cidadã que adquirem no IB. Essas características são reconhecidas na educação não formal, em que o trabalho conjunto com a comunidade é responsável pela sustentabilidade e a continuidade dos projetos. Gohn (2010, p. 34), afirma que esse tipo de trabalho voltado para a cidadania vem da intencionalidade que demarca o objetivo dentro da educação não formal.

O IB trabalha constantemente para a cidadania e a transformação social. O trabalho como educador no Instituto vai além de ensinar música. Para ser educador no Instituto, não é obrigatório aprender um instrumento musical. Há pessoas como o aluno Márcio, citado por Ricardo Amorim, que passou pelo Instituto e não conseguiu desenvolver habilidades em um instrumento, não conseguiu sequer estalar os dedos, mas conseguiu educar os alunos do projeto na informática e ser um multiplicador no projeto. Isso é afirmado pelo coordenador do projeto:

[...] a gente sabe por questões de estudo mesmo de pesquisa que isso dá resultado pra questão de cidadania, [...] pra inclusão. O Márcio, foi o único batucadeiro que passou por aqui que não batucava. Ele não conseguia estalar o dedo. Mas ele era muito bom na parte de apoio pedagógico [...] [Eu] falava "Márcio você foi o único batucadeiro que passou [no Instituto Batucar] e não tocou violão, não batucou". Mas [ele] era [um] gênio, tanto [que] ele ficou responsável pelo laboratório, que a gente tinha de informática. [Ele] fez com o primeiro semestre de bolsa dele, passou numa faculdade, $[\ldots]$ ganhou bolsa integral pro curso inteiro, segundo semestre ele foi trabalhar no site, saiu do Instituto foi trabalhar no site do SEBRAE, e hoje ele está [...] no senado, entendeu? E assim e é chefe, entendeu? Então são histórias assim muito nos padrões social [...] (Entrevistas, RICARDO, p. 27).

Nas palavras do coordenador Ricardo, percebe-se que a formação de multiplicadores está voltada para a formação cidadã e para a transformação social dos alunos, os multiplicadores colaboram com seus talentos. O projeto contribuiu para a mudança da realidade social do Márcio, no sentido de que ele atuou no projeto como multiplicador, foi incentivado a estudar com uma bolsa de estudos e conquistou seu espaço no mercado de trabalho. Segundo Gohn (2010, p. 70), a cidadania "tem que ser qualificada e construída na 
prática" pelos movimentos sociais e os valores e as diferentes visões dos projetos interferem diretamente na ação do processo participativo.

\section{3 “TRANSFORMAR VIDAS”: O OBJETIVO PRIMEIRO}

O objetivo principal do IB, portanto, é transformar para a cidadania. Segundo os educadores, se acontecer a aprendizagem musical, isso é bom, mas não é o principal. Alceu confirma:

Transformar vidas. Eu acho assim, transformar vidas é dar direção assim pras pessoas sabe? Na vida (Entrevistas, ALCEU, p.108).

No IB, os educadores orientam os alunos em suas escolhas, vocações e objetivos de vida. Isso acontece pelo fato de muitos alunos não terem uma estrutura familiar favorável e estável. Alguns não têm pais ou os pais são ausentes. Para eles os educadores são considerados conselheiros em quem eles podem confiar, com quem eles podem conversar e por quem serão ouvidos. Freire (2011, p. 111) afirma que o educador aprende a escutar e é escutando que ele aprende a falar com seus alunos.

As opções de cultura e lazer na região do Recanto das Emas são mínimos e muitos alunos do IB veem o espaço como oportunidade de desenvolver e explorar os seus conhecimentos musicais.

Participar do IB significa abrir portas para o conhecimento e para oportunidades de trabalhos em apresentações artísticas dentro e fora da cidade. Como diz Paulo, um dos multiplicadores:

[...] mas aqui você não precisa ser músico, se não sabe, aqui te dão oportunidade de você ter a música pra você se tornar e aprender. Vai também ensinar ser pessoas melhores, até nesse bate-papo aqui, a gente vai se descobrindo. Até o que a gente não sabe vai ouvindo e aprendendo. Eu continuo aqui porque [...] é a oportunidade [...] ter um futuro de emprego como músico ou ser um professor ou músico [...] (Entrevistas, PAULO, p. 184).

O multiplicador Paulo afirma que o IB oferece a eles a oportunidade de aprender música, a ter uma perspectiva de vida melhor, a ter uma profissão e a melhorar como ser humano. Esse aprendizado acontece nas conversas, nas interações, no diálogo, na roda de percussão corporal e nas reuniões pedagógicas. Isso é importante no IB. Na experiência de Paulo, a aprendizagem é contínua e é apontada como uma das características da educação não formal. 
As palavras de Paulo revelam o sonho de se tornar músico. A música resgata a dignidade humana dos envolvidos e sua autoestima. Eles se tornam sujeitos sociais e responsáveis pela sua trajetória pessoal e profissional. Hikiji (2006) discute a dimensão transformadora da música e o seu resgate social:

\footnotetext{
Qual a alquimia que opera a transformação do universo etéreo, impalpável da música em instrumento concreto de manipulação e transformação do mundo social? Quais os possíveis traçados entre a emoção musical - experiência sensível detonada pela audição e/ou produção de sons organizados - e a constituição de sujeitos sociais? Como compreender a passagem - efetuada sem maiores esforços pelos sujeitos pesquisados - da experiência musical à social, do tocar um instrumento a perceber-se cidadão? (HIKIJI, 2006, p. 71).
}

A reflexão de Hikiji é fruto de sua pesquisa no Projeto Guri, que visa transformar a vida dos alunos, como ocorre no IB. O objetivo de transformação social está associado às práticas educativas em comunidades de vulnerabilidade e situação de risco, como é o caso do IB e do Projeto Guri. Segundo os projetos pesquisados, a definição de "situação de risco" retomada aqui, é caracterizada como crianças e adolescentes inseridos em famílias desestruturadas, com ausência de pai ou de mãe, ou expostas à violência familiar e acesso ao tráfico de drogas na família. Para Hikiji, a "situação de risco" define-se como um conjunto de fatores como: carência material, violência familiar, desemprego, o crime organizado e o tráfico, ausência de lazer. Nos projetos pesquisados por ela, pode-se afirmar que "a arte 'reduz' o risco, ao promover cidadania, integração social, sociabilidade, auto-estima" (HIKIJI, 2006, p. 87).

\subsection{AUTOESTIMA: “ELES PODEM ESTAR ALI”}

O estudo da arte da música nos projetos sociais ajuda o aluno a se desenvolver e o educador tem uma importante contribuição para esse processo. Pois, por meio da música, trabalha-se a autoestima. Isso é um desafio para a maioria dos professores de música nos projetos, pois envolve ações como: promover o desenvolvimento da reflexão autônoma, despertando a sensibilidade, criatividade, autonomia de pensamento; fazer com que o aluno se sinta competente, aprendendo a se valorizar (trabalho com os cuidados com o corpo, por exemplo); promover o prazer; sentir-se importante e autoconfiante, como numa apresentação musical. Como afirma Hikiji (2006): 
$\mathrm{Na}$ análise de projetos de arte-educação realizada pela Unesco, afirma-se que a arte permite que os jovens revelem seus talentos para a sociedade, e que a "interação entre a auto-apreciação e a gratificação pelo reconhecimento social" é uma referência para a construção da auto-estima (HIKIJI, 2006, p. 93).

Tanto no IB como no projeto Guri, a música também tem essa função, de ajudar o jovem e o adolescente na construção de sua autoestima. Ela pode ser trabalhada nas aulas de música e nas apresentações musicais. No caso do IB, esse estímulo é trabalhado tanto nas aulas como nas apresentações artísticas e nos saraus. Para os integrantes, são mais que apresentações musicais, são momentos em que os alunos sentem-se importantes, momentos em que podem expressar suas emoções ao fazer música com o corpo ou com o instrumento musical. E se tornam mais importantes pelo fato de que os alunos se apresentam em lugares em que jamais imaginariam que fossem se apresentar. É o que afirma a pedagoga Giselle:

\footnotetext{
Assim [a] apresentação [...] [é] muito mais importante para os alunos, pra mostrar que eles estão andando por lugares que [não] imaginavam que [...] poderiam estar. [...] No Tribunal, no Senado, [no] TRT, já apresentou na Câmara, então assim [...] você mostrar pra eles que aquele lugar ali [...] muitas vezes não entrariam, [mas] eles estão ali [...] eles podem estar ali, então assim, principalmente na UnB [...] (GISELLE, p. 123).
}

A afirmação da pedagoga Giselle mostra a importância das apresentações musicais para os alunos do IB. Esse é um fato que transforma, no momento, sua realidade, uma realidade geralmente de exclusão. Quando eles têm a oportunidade de estar nesses locais, apresentando uma música por meio do corpo, ou por meio de instrumentos musicais, eles percebem que as situações podem ser mudadas. Seus pensamentos podem ser transformados em pensamentos positivos, confiantes e autônomos diante da vida, isso tudo alcançado pelo estímulo que o ensino de música no IB proporciona.

Estes estímulos ajudam os alunos a tornarem-se pessoas cidadãs, conscientes de suas atitudes. Para Hikiji (2006), a música é um dos fatores essenciais nesse processo. A autora afirma: "se faz música, dança, pintura, para se 'tornar cidadão"” (HIKIJI, 2006, p.96).

A música no IB também tem esse objetivo, educar para a cidadania. Essa afirmação é confirmada pelo educador André Soares, ao afirmar que eles, os educadores do IB, conseguem ver o crescimento dos alunos como cidadãos por meio da educação musical no projeto:

[...] a gente consegue ver o crescimento do aprendiz. Não só o crescimento técnico, mas o crescimento como cidadão mesmo. [...] a forma de falar muda muitas vezes. A forma de falar muda pelo ambiente que a gente tenta proporcionar pra eles, 
[como] enriquecer de todas as formas [como o] vocabulário [dos alunos] (Entrevistas, ANDRÉ, p. 134).

O educador André afirma que o trabalho da música no IB ajuda os alunos a crescer e isto é visível para ele, a melhora dos alunos em relação ao seu vocabulário por exemplo. Isso acontece porque há uma comunicação entre os educadores e os aprendizes. Eles são estimulados a falar e a se expressar melhor, por meio de algumas orientações que recebem dos educadores e dos multiplicadores, por meio de jogo de palavras, que estimulam e aumentam o vocabulário dos aprendizes, como relata André em sua história pessoal:

[...] eu entrei na Instituição eu tinha o quê? Uns 14, 15 anos e o Ricardo tinha uma brincadeira: [...], ele pegava umas palavras que eram muito difíceis de dizer, de ser falada, assim no cotidiano, que a gente quase não usaria e fazia brincadeiras [junto] com músicas. E a gente meio que ficava com essas palavras na cabeça. E uma palavra que eu lembro que ele usou muito foi "prisma". Eu nunca tinha visto falar nessa palavra, tinha ouvido falar na matemática. E aí ele começava a fazer brincadeiras com isso e a gente começava a ter essas palavras, que teoricamente não teria no nosso vocabulário. [...] E [isso] enriquece o nosso vocabulário através de brincadeiras com música, com adivinhação e isso foi enriquecedor e a gente tenta fazer isso com os alunos, os nossos aprendizes (Entrevistas, ANDRÉ, p. 134).

Brincadeiras com palavras novas por meio da música acrescentam e enriquece o vocabulário dos aprendizes, segundo o educador André Soares, responsável pelas aulas de música no IB. Ele foi um dos que presenciou e participou da atividade inicial proposta pelo coordenador do projeto e hoje passa adiante o que aprendeu e da forma que aprendeu. Esse processo demonstra como se constrói a metodologia na educação não formal e como as intencionalidades se consolidam como descreve e defende Gohn (2010).

Assim como André, no projeto Guri alguns jovens trabalham como monitores auxiliando os professores de música. Conhecer os alunos por meio do diálogo e saber ouvir os aprendizes são caminhos para que o projeto atinja o seu objetivo, como afirma Hikiji, (2006): "talvez um caminho para a concretização de objetivos mais amplos seja ouvir, além da música dos jovens guris, seus anseios” (HIKIJI, 2006, p. 99).

Pode-se considerar que, tanto no IB quanto no projeto Guri, são trabalhadas a inclusão social, a autoestima e a cidadania, como fatores que os projetos procuram desenvolver e explorar constantemente em suas atividades, além da técnica no instrumento. Ou seja, o foco não é somente a música, a música é somente um meio para que possam ser trabalhados os valores e a conscientização dos direitos humanos. Essa também é a perspectiva da pedagogia crítica e libertadora de Paulo Freire (2011). 
Os projetos sociais apontados por Hikiji (2006) convergem para as mesmas questões sociais apresentadas no IB e o trabalho é facilitado pelo interesse dos alunos. Sobre isso afirma Martinez (2013):

\footnotetext{
Ao observarmos o Instituto Batucar, percebemos que as pessoas, sejam elas crianças, adolescentes ou jovens, se reúnem para compartilhar de um mesmo interesse - a atividade musical - esse é o ponto que comunga diferentes pessoas, tornando-as um grupo (MARTINEZ, 2013, p. 106).
}

A autora observa que os alunos mostram interesse nas aulas, principalmente porque são um grupo. Os estímulos dos pares, dos educadores, no convívio com os alunos, proporcionam e valorizam o pertencimento, o que gera a alegria e o prazer em aprender, o que os torna confiantes para o seu desenvolvimento como seres humanos.

\subsection{PRÁTICAS PEDAGÓGICO-MUSICAIS}

Os planejamentos realizados pelos professores em diferentes contextos podem mudar conforme a situação de aprendizagem, as interferências externas e internas e o comportamento dos alunos. Planejar é uma atividade presente em todas as práticas educativas e acontece tanto na sala de aula quanto em outros locais,

No caso dos projetos sociais, a educação não formal é a modalidade educacional mais frequente. Neles a prática docente tem ação intencional, como afirma Morandi (2008):

\footnotetext{
A prática docente pode ser em sua dupla dimensão: agir de maneira intencional em uma situação na qual se é ao mesmo tempo o idealizador, o ator e o dirigente procedimentos por realizar; e ser confrontado com outros atores agindo, que são os alunos, e com acontecimentos problemáticos que é preciso resolver em determinada situação - o fazer próprio de cada professor (MORANDI, 2008, p.101-102).
}

A prática em sua dupla dimensão, nas palavras de Morandi (2008), apresenta uma abordagem educativa centrada na compreensão das práticas teorizadas, previstas e das práticas vivenciadas na interação e na experiência, o que gera um saber da prática. Franco (2008, p. 95) destaca a possibilidade de compreensão nas práticas educativas, ressaltando que os professores conhecem sua teoria sobre a sua prática, conhecem tanto o ensinar como o aprender e que há um diálogo significativo nessas relações capazes de uma nova compreensão do seu trabalho educativo.

Nas aulas de percussão corporal no IB, as práticas pedagógico-musicais são desenvolvidas e consolidadas como saberes. Nas práticas pedagógico-musicais observadas, 
são trabalhadas postura corporal, ritmos, dinâmicas de estrutura musical como pergunta e resposta, canto, percussão corporal e o método "O PASSO" idealizado e difundido por Lucas Ciavatta.

No caso da percussão corporal, a atividade consiste em explorar e executar diferentes sons no corpo: boca, peito, palma, barriga, estalo de dedo, pernas, pé. Sobre a percussão a multiplicadora Milena afirma que:

[...] a percussão [tem] várias formas se poder trabalhar. Até a palma desse jeito, o estalo assim [executa os sons com as mãos] fazer [um som de uma] uma caixinha... Então percussão corporal dá muitos leques (risos) (Entrevistas, MILENA, p. 183).

A percussão corporal, segundo Milena, possibilita ao aprendiz fazer vários sons, a partir de um estalo ou através de palmas e, para fazer esse som, pode-se pensar em sons produzidos por meio de objetos, como uma caixinha fazendo um chiado com a boca, faz-se uma boca de peixe e deixa só o barulho, sem som da voz.

Nas aulas de violão, os alunos aprendem postura, acordes, ritmos e ensaiam para apresentações musicais. Os alunos treinam nas aulas em círculo junto com os educadores e os multiplicadores auxiliam nesse processo. Eles sentam perto dos alunos e olham a postura correta do corpo, das mãos, dão dicas de como fazer o acorde. Eles participam do aprendizado dos alunos se colocando à disposição. Assim como no violão, o mesmo acontece com os outros instrumentos, o violoncelo e o violino. Os alunos são separados por instrumentos, organizam-se em círculo e os multiplicadores os auxiliam em suas dificuldades.

Há um quadro na sala onde os alunos de instrumentos podem visualizar os acordes para facilitar a aprendizagem. Os educadores o utilizam para explicar a formação dos acordes trabalhados nas músicas, o que pode ser visto na foto seguinte. 
FIGURA 06: Foto - Aprendizado dos acordes das aulas de teoria musical

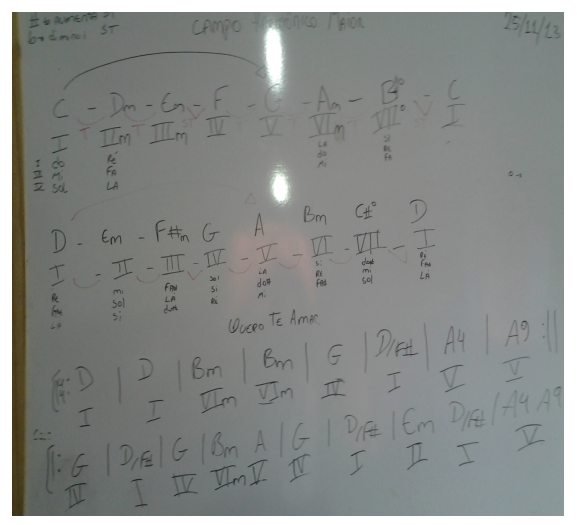

Fonte: Foto minha, trabalho de campo, 2013.

Por outro lado, na aula de prática de orquestra, eles executam arranjos musicais e repertório específico, desenvolvem leitura musical e, em um dia específico, um grupo de alunos tem aulas de performance em conjunto. Nessa aula, os alunos aprendem a postura correta do corpo, dos braços, criam e ensaiam peças para as aulas semanais no projeto. A prática de orquestra é realizada pelos multiplicadores, cada um com seu instrumento: violão, violoncelo, violino e um teclado, conduzidos por um maestro. Os alunos reúnem-se uma vez por semana para essa prática. Eles aprendem a tocar lendo a partitura e iniciam com exercícios mais fáceis até chegar a peça musical.

Tanto na aula de violão como na aula de prática de orquestra, o "educador" e os multiplicadores trabalham juntos. Formam-se grupos de alunos em que cada educador e cada multiplicador orienta, propõe exercícios e auxilia nas dificuldades com o instrumento. A postura e a autonomia dos multiplicadores trazem segurança para os alunos e motivação para a sua aprendizagem. Leonardo afirma:

[...] o que você faz e acaba se especificando naquilo, você acaba criando conhecimento a partir do conhecimento, [e] você pode passar isso pra frente [...] (Entrevistas, LEONARDO, p.180).

O multiplicador Leonardo mostrou-se bastante confiante no IB ao afirmar que ele propicia "um conhecimento", ou melhor o seu conhecimento, a partir dos conhecimentos adquiridos no seu instrumento e isso na prática. As práticas pedagógico-musicais são a "alma" do IB. Elas acontecem nas aulas, na orquestra, nos ensaios, nas apresentações musicais, dentro e fora do IB. 
Nas aulas observadas por mim, foram trabalhados exercícios como: pergunta e resposta, flecha, peça musical do grupo de percussão corporal Barbatuques, ${ }^{16}$ jogo da percussão corporal, além de aulas de instrumento, de orquestra e de ensaios para apresentações musicais. Todas essas práticas musicais começavam com uma roda: a roda de percussão corporal. A roda é estimulada pelo educador e sua função é conduzir os alunos a formar um círculo. Nessa roda todos podem se olhar, o que facilita o aprendizado por meio da observação e da percepção dos outros. Nesse sentido, Oliveira, Morais e Braun (2010), afirmam que

Sentar em roda convida a que cada aluno olhe no olho do outro, que veja e leve em conta as reações do outro diante de seus discursos. Convida a fala mais circulante e não centrada na figura docente (OLIVEIRA; MORAIS; BRAUN, 2010, p. 248).

O condutor no momento das aulas fica no meio da roda, mas a todo momento circula entre os alunos, dando-lhes a atenção necessária para estimular sua postura para o aprendizado da percussão corporal. O educador olha todos os alunos nos olhos, motivando-os a batucar, a fazer o que está sendo proposto. Às vezes, alguns alunos chegam meio sonolentos, outros, meio cansados, mas quando começa a aula, os alunos parecem acordar e se animar e, sem perceber, já se veem batucando e sorrindo uns para os outros.

A roda de percussão corporal consiste em um grande círculo em que todos dão as mãos para organizar a roda. Depois que todos estão conscientes do círculo feito, todos soltam as mãos e permanecem no mesmo lugar. É feito um alongamento e aquecimento do corpo, da voz e dos movimentos corporais. São eles: espreguiçar o corpo, bocejar, mexer com os lábios superiores e inferiores, dar pequenas batidas de leve com as mãos no peito, costas, pernas e flexionar os joelhos, fazer de conta que há uma mola no joelho e que se pode movimentá-lo para em diferentes direções.

Junto com o alongamento e aquecimento, algumas expressões surgem como motivação, elas são emitidas no momento da percussão corporal que exige dos alunos uma postura correta, concentração e swing, para que o exercício flua naturalmente, sem esforço

\footnotetext{
${ }^{16}$ Barbatuques: é um núcleo artístico e pedagógico que há quase 20 anos pesquisa e desenvolve uma linguagem pioneira de percussão corporal: a expressão musical através dos inúmeros sons que podem ser produzidos pelo corpo humano. O grupo atua há vários anos no Brasil e no mundo, realizando trabalhos com outros grupos artísticos, escolas, fundações culturais, ONGs e universidades.

Estas atividades são direcionadas às necessidades das empresas e ministradas por integrantes do Núcleo Barbatuques, sob a supervisão do seu fundador Fernando Barba.

Fonte: http://barbatuques.com.br/pt/

Acesso em 25/11/14
} 
físico. Expressões como: "Molinha no joelho", "perna flexionada" são usadas com frequência pelo educador, para facilitar a consciência rítmica corporal e a aprendizagem. Durante a atividade, o educador mostra no corpo como é essa "molinha no joelho", flexionando a perna e enfatizando o movimento "perna flexionado". Em seguida, os alunos observam e imitam.

Além das aulas de percussão corporal e instrumentos, a conversa entre os educadores e os alunos é sempre presente. Um exemplo foi observado em aula no IB quando iniciou-se a aula com os alunos sentados em círculo, nas cadeiras, embaixo da tenda (uma lona, tipo formato de circo). A coordenadora pedagógica, Patrícia Amorim, deu início à aula de música com algumas recomendações aos alunos: chegar às 7h30min para organizarem o espaço (varrer, limpar e organizar as cadeiras), para que as atividades comecem pontualmente às 8 horas. Ela também pergunta sobre o dever de casa. E acrescenta "eu acho legal vocês cuidarem desse espaço, pois ele é de vocês, não é dos professores, é de vocês que estão aqui toda a semana. Cuidem do espaço, dos banheiros. Cuidar com os papéis de balinha no chão, a gente ajuda e começa a respeitar mais o colega". Após essa introdução, os alunos se dirigem para a sala para a aula de música (DIÁRIO DE CAMPO, março, 2013, p. 07).

O exercício de promover a cidadania e a inclusão social é vivenciado no diálogo, que demonstra o cuidado e a atenção que os educadores dedicam aos alunos, considerando-os parte do IB, como aqueles que são o próprio IB. Assim, os alunos não frequentam o IB somente para ter aulas de música, eles estão todos os dias no local cuidando do espaço físico em atividades como lavar o chão, banheiros, limpar cadeiras, organizar os instrumentos e mantê-los afinados. Para essas atividades, é marcado um dia na semana para que todos participem dessa atividade, juntamente com toda a equipe, ou seja, todos são envolvidos em todas as atividades agendadas pelo IB. Muitos alunos e multiplicadores, ainda estudantes do ensino fundamental e do ensino médio da escola pública da região do Recanto das Emas, frequentam o IB à tarde ou à noite, quando estão em horário livre, somente para conversar com os educadores do IB. Então, para alguns, o local é considerado como uma outra família. Isso é confirmado através da fala da multiplicadora Vânia:

\footnotetext{
Assim acabei vindo e gostando. Não foi por acaso, porque tinha a igreja e minha mãe trabalhava lá. [...] Um dia à noite eu fui lá com ela. [...] Quando eu cheguei estava [acontecendo a] aula de percussão. Eu achei muito engraçado porque [era] uma aula bem diferente, eu nunca tinha visto aquilo. Aí meu irmão dava aula também. Eu comecei a vir e me interessei e fiquei até hoje. Eu lembro que às vezes [...] a gente passa a nossa metade do tempo aqui, acaba virando uma outra família (risos) (Entrevistas, VÂNIA, p. 163).
} 
As atividades pedagógico-musicais dos multiplicadores ocorrem também no Centro de Ensino Fundamental 113 do Recanto das Emas (C.E.F. 113/Rec Emas). Ao observar as aulas dos multiplicadores na escola, presenciei o início da atuação de alguns multiplicadores. Eles não atuavam sozinhos, inicialmente eram acompanhados pelos educadores até que se sentissem seguros. Nas aulas observadas, os multiplicadores reproduziam a metodologia vivenciada no IB: eles começavam a percussão corporal com exercícios introdutórios, alongamento, aquecimento e exercícios sonoros como o estalo, palma e peito, sons que têm ritmos variados como o funk, o samba, o baião, por exemplo. Eles podem ser visualizados na Figura 7 a seguir.

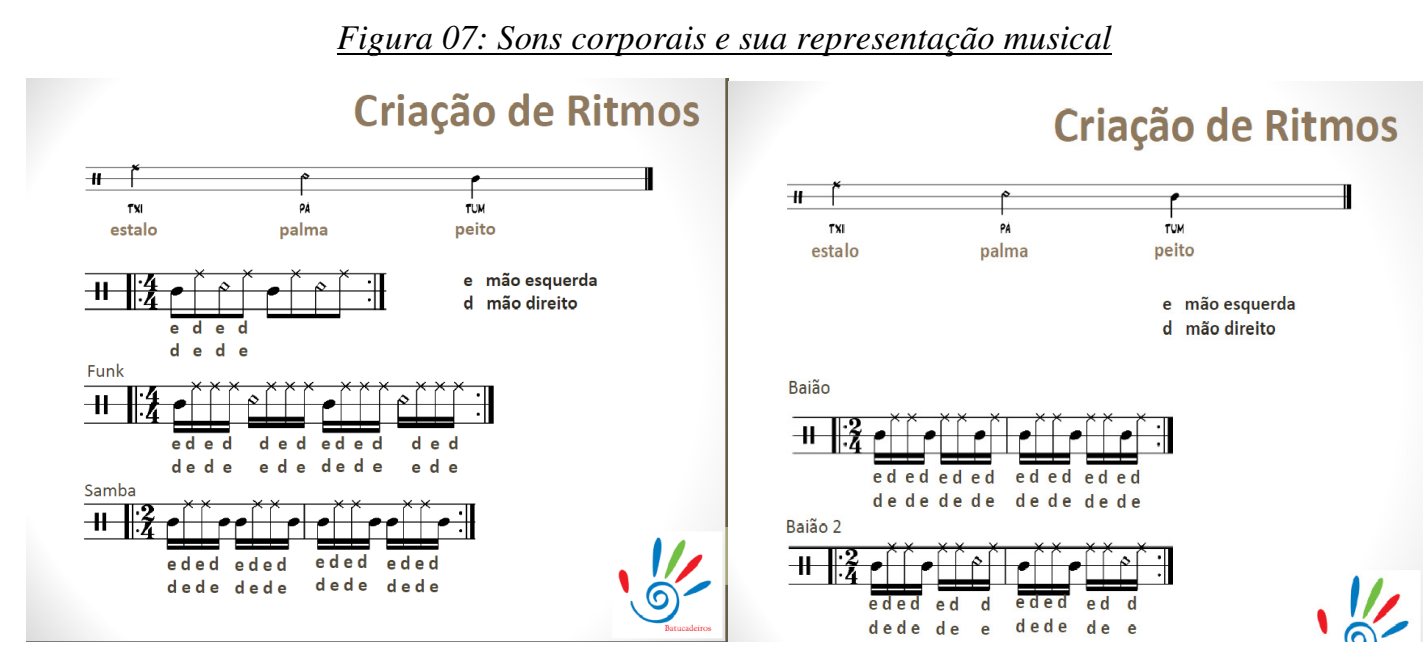

Fonte: BATUCADEIROS, 2013, p. 18-19.

$\mathrm{Na}$ aula do dia 24 de junho de 2013, no C.E.F. 113/Rec. Emas, os alunos começam a chegar e André e os multiplicadores trazem os instrumentos. Eles abrem a sala e aos poucos os alunos entram com grande euforia. Sentam e conversam uns com os outros. Enquanto isso, os multiplicadores afinam os instrumentos e pedem silêncio. Outros alunos entram na sala e chegam conversando com todos. Aos poucos os multiplicadores entregam os violões afinados para os alunos. Um multiplicador começa então a aula revisando o que foi trabalhado na aula anterior. Como nem todos lembravam a música, foi proposto que os alunos ficassem sentados um de frente para o outro: aquele que sabia tocar se sentava de frente para o aluno que não se lembrava da música, no caso "Pais e Filhos", da banda brasiliense Legião Urbana. A aula inicia-se com a prática dos acordes G (SOL Maior) e C9 (Dó Maior com nona). O multiplicador ensina com muita paciência esses acordes para aqueles que não aprenderam ainda. 
Os alunos do CEF 113/Rec. Emas são da mesma região dos alunos do IB. Apesar de ser da mesma comunidade, as aulas são muitas vezes interrompidas para chamar atenção de alunos que não estão prestando atenção ou que só querem ir para a aula para conversar, o que torna a aula mais desafiadora para os multiplicadores que estão iniciando sua aprendizagem como educadores. Ao longo das aulas e com a ajuda dos educadores do IB, os multiplicadores vão vencendo desafios como se aproximar mais dos alunos e manter a disciplina, o respeito e os valores humanos em sala de aula.

Os multiplicadores repetem os procedimentos que vivenciam nas rodas de percussão corporal no Instituto. Leonardo relata que inicia sua aula na escola com alongamento e que depois acontece um "diálogo rítmico" entre ele e os alunos. Esse diálogo consiste em uma atividade de imitação, primeiro, o educador bate uma palma e em seguida bate com a mão na boca e, em seguida, o aluno repete. E assim ele começa a fazer outros tipos de combinação de timbres da percussão corporal, passo a passo, e o aluno repete. Nesse momento não há um diálogo oral, mas um diálogo utilizando a percussão corporal. Em seguida, ele organiza a turma e inicia o ensino de uma peça de percussão corporal, ou seja, o passo a passo, e os alunos aprendem uma sequência de movimentos rítmicos com a percussão corporal. Os alunos treinam e, por fim, são reunidos para a execução da performance da peça. Com os alunos reunidos em um único grupo, o educador dá as instruções para o início da peça. Todos em silêncio concentram-se e aguardam o comando para o início. É orientado o início e todos os alunos juntamente com os multiplicadores começam a peça, que consiste em uma sequência de ritmos com o corpo. Há momentos em que os multiplicadores tomam a frente para começar uma outra sequência de ritmos na mesma peça. Alguns alunos são mais extrovertidos. Os mais introvertidos são auxiliados pelos multiplicadores, mas no geral todos eles conseguem fazer as percussões, ao observar e ouvir uns aos outros no dia a dia.

Segundo Neto (2010, p. 52), a formação do educador social é permanente e acontece na prática. Ela é contínua e a cada encontro com os educandos ou com acontecimentos cotidianos, surgem alterações e adaptações na sua forma de pensar, operar, e de ser. Os multiplicadores do IB formam-se ao ensinar, ao auxiliar os educadores, ou seja, sua formação acontece todos os dias no projeto, nas interações sociais e nas vivências cotidianas.

Eles aprendem, na prática, estratégias de ensino como: introduzir algumas brincadeiras e estimular a aprendizagem colaborativa, em que os alunos aprendem e também ensinam os colegas que estão com maiores dificuldades. Observando algumas aulas, percebi que não foi fácil para os multiplicadores controlar a disciplina dos alunos, pois muitos 
pareciam estar ali para brincar e conversar. Mas a intenção dos educadores e multiplicadores é promover disciplina e a motivação assim como ocorre com os alunos do IB.

\subsection{OS MULTIPLICADORES - APRENDER A SER EDUCADOR}

O ensino e a aprendizagem da música estão inseridos no projeto social Instituto Batucar onde as aulas geralmente acontecem em grupos e há uma interação entre aluno e professor, professor e aluno. Nos espaços de aprendizagem não formal, como é o caso dos projetos sociais, a interação entre professor e aluno é dialógica e o professor é um facilitador das atividades. Este pode ser reconhecido como educador, instrutor, oficineiro, mediador, facilitador ou multiplicador. Nesses locais, a aprendizagem é, principalmente, compartilhada e visa atender às demandas da comunidade.

Nos projetos sociais, a aprendizagem do educador também acontece com o outro. Sobre essa questão, Gohn (2010) afirma que o educador nesses espaços não formais é o "outro", aquele com quem o profissional interage e se integra. Mas para que isso aconteça é necessário que haja, por parte do profissional, uma adaptação ao meio social daquele grupo social, ou seja, daquele grupo específico, para que se possam construir vínculos sociais e o aprendizado aconteça naturalmente, por meio de uma ação compartilhada.

Morandi (2008) também reflete sobre a questão dessa intenção de educar, desse compartilhar, em que a pedagogia liga os valores ministrados à questão da preocupação com o outro.

No caso do IB a preocupação com o outro é evidente, onde aprender, ensinar e conviver socialmente são os objetivos e estão presentes no cotidiano de todos.

No IB, além de terem experiência como professores e como auxiliares dos educadores, os multiplicadores, como já dito, também ministram oficinas de música para alunos da educação integral, no projeto Mais Educação, projeto do governo do Distrito Federal, no C.E.F. 113/Rec. Emas. Assim como os educadores do Instituto, os multiplicadores consideram-se aprendizes e algumas vezes professores. Ao falar sobre sua experiência como uma multiplicadora no C.E. F. 113, Vânia relata:

\section{[...] sou mais aluna que professora (Entrevistas, VÂNIA, p.163).}

Émile relata que a oficina de música 
[...] é um compartilhamento de experiência (Entrevistas, ÉMILE, p. 188).

O educador André reconhece :

[...] então, é uma troca de experiência que a gente faz dentro da aula, e é também uma questão que não trabalha só musicalização, trabalha a interação, o social (Entrevistas, ANDRÉ, p. 129).

A fala do educador André retrata o que é a aula de música no IB. Nela não é trabalhada somente a musicalização, mas a interação social. Os alunos interagem com os educadores, dialogam, trocam aprendizados, o que gera uma troca de experiências na aula. Émile identifica um compartilhamento das experiências adquiridas no IB. Essas experiências são os conhecimentos adquiridos no Instituto e/ou referências acumuladas durante a trajetória de vida que são postas em prática no projeto.

Tanto os alunos como os multiplicadores apropriam-se do IB como parte da sua vida profissional, assim como da sua vida pessoal, como cidadão. Percebi que os multiplicadores sentem-se aprendizes, mesmo aqueles que estão há muito tempo no IB, assim como também todos os educadores do IB.

Os multiplicadores no IB são jovens alunos que depois de um tempo, adquiriram habilidades em algum instrumento e na percussão corporal como já foi enfatizado. Ao passar do tempo, eles começam a auxiliar os educadores nas aulas, por meio de atividades como afinar os instrumentos, ajudar a organizar os alunos, auxiliar em suas dificuldades, ao mesmo tempo em que os educadores estão ministrando a aula de música. Eles também ministram as aulas de música com o auxílio de um educador do IB. André, que hoje é educador começou como multiplicador.

[...] a gente começou a ter que dividir os grupos em adolescentes e crianças. Foi nessa época que eu comecei mais ou menos a passar pra parte daqui: começava a dar aula. [O] Ricardo ficava monitorando incentivando a gente para poder começar a dar essas aulas (Entrevistas, ANDRÉ, p. 125).

Essa fala retrata o momento em que o educador André iniciou sua trajetória pedagógica no IB. Ele considera o IB como um laboratório de aprendizado, em suas palavras,

Olha, o Instituto é como um grande laboratório. Tudo o que eu aprendi, [e] toda a minha forma de aula que eu tenho hoje, foi baseada no aprendizado como [...] aluno e algumas coisas que a gente foi criando junto, eu e o Ricardo. Porque eu nunca tive 
uma aula particular assim individual, eu já tive aula na instituição no começo mais nunca foi uma aula individual [...] (Entrevistas, ANDRÉ, p.136-137).

O educador André coordena, juntamente com o coordenador do IB, o grupo de performance. Nele são trabalhadas peças para as aulas no IB. O grupo é composto por alunos e multiplicadores. Os erros que os alunos cometem em um exercício de percussão corporal são aproveitados e transformados em uma peça para percussão corporal.

$\mathrm{Na}$ entrevista realizada com os multiplicadores, perguntei-lhes como eles haviam se tornado multiplicadores. A sensação que eles me passaram é que eles nem perceberam essa passagem de aluno para multiplicador. Uma das falas confirma essa sensação:

"Eu entrei foi o um mês, tava um mês assim, vinha à noite [para o] ensaio, [...] todo mundo assim e eu fiquei só foi uma peça, fiquei só [...] e aí foi” (Entrevistas, RAÍSSA, p. 162).

Portanto, o papel dos educadores é muito importante para o aprendizado, as interações, a autoestima dos alunos e para que a inclusão social aconteça no IB. As crianças demonstram gratidão pelo carinho, amor e atenção dos educadores. Isso fica evidente quando a aula acaba: todos os alunos são acostumados a abraçar os educadores, conversar e alguns ainda ficam no IB conversando depois das aulas e dos ensaios.

\subsection{1 “Ôxe aprende demais moço!’: Aprender e ensinar na prática}

Ao entrevistar um multiplicador do IB sobre o que eles pensam sobre aprender e ensinar, Leonardo inicia sua resposta da seguinte forma:

\footnotetext{
"Ôxe aprende demais moço! O aprendizado com um aluno meu... [Ele] falou assim: 'ô tio você não sabe tocar é nada!' [risos] [...] aprendi com ele que, tipo assim, pra ser professor..., eu falei: cara tem que ter a mente aberta pra tudo, sabe?"(LEONARDO, p. 191).
}

O multiplicador Leonardo afirma que o educador precisa estar com a mente livre para ouvir, disposto a aprender com o próprio aluno. Essa afirmação traz reflexões pertinentes sobre a formação do educador nos dias atuais por meio da prática na interação com o aluno, compartilhando e construindo saberes na sua prática educativa.

Azevedo (2007) entende que a formação é "um processo contínuo de desenvolvimento humano e profissional, que compreende uma história pessoal; uma aprendizagem docente em cursos especializados no início e durante a carreira; e uma 
experiência e prática na profissão" (AZEVEDO, 2007, p. 31). O profissional forma-se em cursos, através da sua prática docente e com a sua experiência pessoal e pedagógica. Segundo a autora, a formação docente formal e pessoal promove a sua qualificação. No IB não ocorre uma formação docente institucionalizada e reconhecida profissionalmente como a que se desenvolve em cursos de licenciatura. Contudo, há uma formação para a ação educativa que visa a replicação e ampliação da ação social do projeto. A formação ocorre na vivência dos princípios e práticas pedagógico-musicais do projeto sob orientação dos coordenadores, pedagogas e educadores do IB. Nesse processo, da experiência cotidiana e da história pessoal de cada um, são construídos saberes.

Os integrantes do IB, educadores e multiplicadores relatam uma experiência musical associada à família e à Igreja. Eles trouxeram para o Instituto suas experiências musicais como professores de música particular e apresentações em bandas, como equipe de louvor da igreja, além de terem influências familiares, irmãos músicos e estudos em escolas de música de sua cidade. Os saberes da experiência dos multiplicadores se constituem em suas experiências pessoais e nos saberes com todos os alunos e educadores do IB, colaborativamente. Eles aprendem a postura, a coordenação motora, os movimentos propostos pelos educadores. Também adquirem valores humanos por meio dos quais aprendem a conviver e interagir com todos. Eles convivem constantemente com a experiência de ser professor no projeto e ao mesmo tempo afirmam serem aprendizes desse processo:

[...] é a gente vive constantemente experimentando ser aprendiz e ser professor, ser aprendiz e ser professor [...] (Coordenador RICARDO, p. 42).

Todos se encontram em processo de aprendizagem no IB, pois ao ensinar os alunos inseridos no projeto, todos são também aprendizes. Patrícia Amorim destaca esse princípio:

[...] aqui dentro a gente trabalha dessa forma né: que todo mundo ensina, todo mundo aprende [...]. Você tem capacidade pra ensinar, até a pequenininha de 06 anos que é a idade mínima que nós temos aqui (Entrevistas, PATRÍCIA, p. 84).

O processo de ensinar e aprender envolve a participação dos multiplicadores, que são formados durante o processo em que estão sendo integrados ao grupo. Suas famílias inscrevem seus filhos e existe uma lista de espera no IB. Quando são chamados para frequentar o Instituto, participam das atividades desenvolvidas por meio da música. A partir de então, começam a desenvolver habilidades musicais em algum instrumento e começam a 
participar do processo de aprender a ensinar outras pessoas. A multiplicadora Ana afirma ao se referir à sua formação como multiplicadora:

"Ué a gente a gente treinou tudo aqui! (risos) a gente não tem aula diretamente como multiplicadores..."(Entrevistas, ANA, p. 182).

O processo de se tornar multiplicador dentro do IB acontece na prática diária, no contato, nas aulas de música, na interação com os alunos, na observação e na imitação em que os educadores são os exemplos a serem seguidos. Assim como defende Kleber (2006d, p. 84), ser multiplicador no IB não se resume em saber ensinar e aprender música, mas envolve a convivência com a família, com a escola, os encontros no IB, os ensaios, os saraus e as apresentações artísticas na cidade. Todos esses aspectos caracterizam o IB e retratam a sua história e os aprendizados diários refletidos na vida de cada integrante.

Segundo Ricardo Amorim, o projeto multiplicadores começou quando os melhores alunos, tanto na percussão corporal, como nos instrumentos, começaram a atuar como facilitadores. Houve então uma preocupação com a formação de multiplicadores.

[...] então a gente começou a formação de multiplicadores que foi também muito no começo, acho que 2004, por aí a gente já estava com essa ideia de bolsista e trabalhando pra que esses bolsistas fossem remunerados. Então a gente teve um grupo muito legal de adolescentes que foram um dos primeiros que estavam comigo em 2001, 2002, [...] eles começaram a ganhar a bolsa e assumir essa liderança dentro da proposta do projeto. Então tinha dever de casa, tinha o monitor de percussão corporal. A gente começou a criar, com os projetos entrando, [...criamos] os dias de atendimento, então começou a ter atendimento de manhã, de tarde (Entrevistas, Coordenador RICARDO, p. 09-10).

Os atendimentos foram crescendo no projeto. Giselle, por exemplo, começou como aluna no Instituto e contribuiu tornando-se uma multiplicadora, auxiliando tanto no acompanhamento pedagógico como na percussão corporal.

$\mathrm{Na}$ foto a seguir, Giselle filma uma peça criada no momento pelos educadores e multiplicadores: 
Figura 08: Foto - Gravação de uma peça

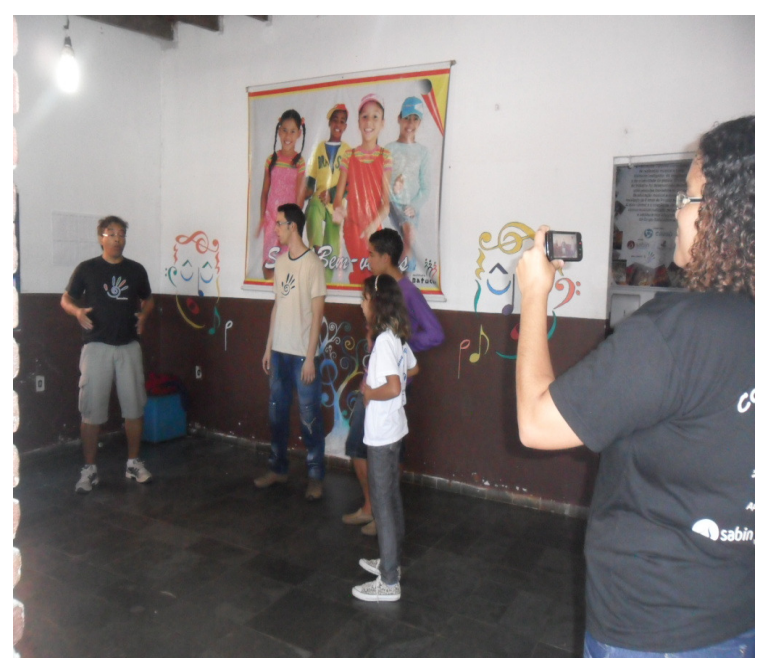

Fonte:Foto minha, trabalho em campo

Patrícia relata como foi o processo de formação da Giselle como multiplicadora dentro do IB:

E aí ela [Giselle] começou a atender e começou a dar certo e aí ela começou a [...] fazer percussão corporal junto com [...] outra aluna da época, a Joelma. Elas começaram a atender no domingo à tarde também com percussão corporal, [para] os pequenos, e durante a semana a Giselle fazia esse atendimento de jogos pedagógicos, de jogos lúdicos e também [...] percussão corporal (Entrevistas, PATRÍCIA, p. 67).

O acompanhamento pedagógico faz parte das atividades desenvolvidas pela pedagoga Giselle, que aprendeu na prática a acompanhar crianças com dificuldades escolares e a ensinar percussão corporal. Em sua entrevista, ela relatou que quase não percebeu sua transição de aluna para educadora no IB. Durante esse processo de acompanhamento pedagógico, foram encontrados alguns problemas como a falta de apoio das famílias dos alunos atendidos. Com a orientação pedagógica, os pais passaram a discutir a responsabilidade educacional com os educadores do IB. Contudo, esse trabalho começou a prejudicar a participação dos pais na escola, pois, alguns pais começaram a deixar de participar das reuniões escolares dos seus filhos, porque esperavam que os educadores do IB fossem às reuniões para avaliarem os efeitos que o acompanhamento pedagógico estava produzindo na vida dos atendidos.

Esse problema trouxe reflexões e questionamento para os coordenadores do IB. Em virtude do acontecido, decidiu-se realizar um novo projeto em que a família pudesse 
conscientizar-se do seu importante papel no desenvolvimento cognitivo do seu filho, assim como da importância de sua presença na vida escolar da criança.

[...] aí foi quando a gente esse ano de 2013, a gente lançou o desafio "pais presentes filhos inteligentes". Então que projeto é esse, ainda tá muito no comecinho, a gente ainda tá começando, a gente ainda tá dando um suporte de apoio pedagógico, [...] duas vezes na semana [...] é um desafio pra nós também [...] (Entrevistas, Coordenadora Pedagógica PATRÍCIA, p. 69).

A partir desse fato, o IB aproximou a família tanto para o filho, como para o IB. As famílias passaram a ser mais participativas na vida do filho. E esse apoio, tanto familiar quanto do IB, contribuiu para que o aluno tivesse prazer em estudar. Para Cortella (2002), "a educação é um fenômeno existencial" (p. 97): ela acontece em toda a nossa existência, do nascer à morte e também é vital, pois acontece enquanto existimos. E assim como temos possibilidades de aprender, também temos a necessidade de estar sempre aprendendo.

A percussão corporal no IB atrai, fascina e motiva os multiplicadores. Ser multiplicador é mais do que divulgar o trabalho, é compartilhar alegria e prazer. Leonardo demonstra a "magia" que percebe na percussão:

\footnotetext{
A percussão faz o seguinte com a gente, você chega lá querendo fazer só uma coisinha, só uma coisinha se faz assim ó, [bate palma] [...] isso aqui é mágico! (Risos) [...] [você] pode copiar do seu amigo, pode imitar, [você] pode se entregar. Então quando eu comecei a aprender a percussão foi essa coisa mágica, que você pode contribuir [com o] você pode dar, o que você faz pode virar peça, a minha primeira aula foi assim [...] (Entrevistas, LEONARDO, p. 167-168).
}

As oficinas de música acontecem em grupo e, nesse grupo, todos aprendem uns com os outros. Para os multiplicadores, a percussão corporal é algo inovador e eles consideram música os sons que eles fazem com o corpo. Os multiplicadores têm consciência das habilidades que são desenvolvidas na percussão corporal como a coordenação motora por exemplo. É o que relata a multiplicadora Roseli:

“[...] você desenvolve sua coordenação [e] não só a coordenação [e] o controle do corpo, [...] o cérebro também desenvolve muito, [você] aprende as coisas mais rápido! [...] A percussão é uma coisa inovadora [...]” (Entrevistas, ROSELI, p. 166).

Segundo a multiplicadora, o estudo da percussão corporal fez com que ela aprendesse mais em relação à sua coordenação motora, por meio dos ritmos que são utilizados nesse tipo de exercício. Ela afirma ter aprendido mais rápido os exercícios considerando um controle tanto do seu corpo como do cérebro. 
Nesse sentido, o compromisso com as oficinas, tanto da parte dos educadores como dos multiplicadores do projeto, demonstra autonomia no ensino da música nesse local, assim como a satisfação e a alegria em trabalhar no Instituto, mostrando prazer em ensinar e aprender.

A experiência no Batucar é replicada e transferida para as oficinas de música no C.E.F. 113. Assim, a metodologia vai se consolidando:

[...] É a gente [...] faz o aquecimento, alonga [...] Depois [...] antes de passar o conteúdo todo, a gente só faz o que a gente chama [de] pergunta e resposta, [...] a gente vai colocando [o] mi, [o] fá, [e eles] repetem [no instrumento] e cada um faz o seu e depois faz passo a passo a peça. Como eu [estou] geralmente com a Virgínia, a gente pega divide cada [aluno]. [...] Depois a gente reúne todo mundo, [...] os que sabem e os que não sabem [...] (Entrevistas, LEONARDO, p. 160).

Ao conversar com os educadores e coordenadores, pude constatar que todos têm um sonho em comum, todos têm o desejo, uma perspectiva futura de um IB com o seu próprio espaço, com todos os seus recursos materiais e estrutura física apropriada. Como afirma Ricardo Amorim:

A gente tá caminhando pra uma Universidade Livre de Música, experimentação musical [...] (Entrevistas, Coordenador RICARDO, p.59).

O administrador do IB, Alceu também relata os projetos futuros para o IB:

[...] ideia de tornar um ponto de cultura do Recanto das Emas, e além [do] ponto de cultura, eu acho que a gente vai caminhar pra uma universidade mesmo, uma escola de música também, então porque a gente não pode separar [...] a nossa prática que é música, com aquilo que a gente quer fazer, que é promoção de cultura, com a transformação de vida, essas coisas vem através da música, então acho que vai ter, eu acho que vou ter duas frentes e um lugar só entende? (Entrevistas, ALCEU, p. 109).

Ele complementa:

“[...] o sonho é que [...essa] estrutura ideal seria uma estrutura de escola mesmo, de universidade, de salas, de bastante salas, varandas, área de lazer, de ventilação de iluminação mesmo solar mesmo natural [...]” (Entrevistas, ALCEU, p. 103).

Um grande ideal e perspectiva de Patrícia Amorim é remunerar melhor os educadores do projeto, aumentar a equipe e trazer de volta educadores que passaram pelo projeto como assistentes sociais e outros professores. Enfim, ela gostaria de mudar a situação financeira do IB, que apesar de ter algumas parcerias, precisa contar com o apoio da Igreja e 
com a ajuda de algumas famílias de alunos do Instituto, que contribuem livremente para o projeto.

Além da sustentabilidade do projeto, uma outra perspectiva futura é a gestão participativa que já se iniciou com "a mesa", momento em que todos os educadores e multiplicadores se reúnem para discutir as oficinas, os trabalhos e os projetos do Instituto. $\mathrm{Na}$ mesa, os multiplicadores são orientados quanto à sua prática e assuntos voltados para a educação musical. São discutidos os problemas encontrados e possíveis soluções, trata-se a respeito do comportamento dos alunos, além de se colocar em pauta assuntos relacionados aos trabalhos do IB, tanto internamente como externamente. Também é durante esse momento que o grupo conversa a respeito das apresentações artísticas. Nesse trabalho da "mesa" há crianças e adolescentes. Ricardo Amorim relata o início desse trabalho importante dentro do IB:

\begin{abstract}
A gente quer estender esse trabalho aqui pras crianças. A gente começou com os adolescentes porque é um grupo de foco nosso, assim, então, começamos [em] janeiro eu, Giselle, Alceu e André, que fazíamos a base do trabalho, [...] do Batucar, [onde] assumimos as responsabilidades institucionais. Depois trouxemos os adolescentes, multiplicadores, mas a meta nossa é que tenhamos as crianças, [...] na parte do gerenciamento, [da] gestão do projeto (Entrevistas, Coordenador RICARDO, p.37).
\end{abstract}

O que o coordenador Ricardo propõe é a gestão participativa no IB, que consiste em preparar todos os integrantes para que sejam responsáveis pela instituição. O objetivo é que essa responsabilidade seja dividida entre todos os participantes do projeto, em que todos sejam capazes e tenham autonomia para liderar o IB.

O Capítulo 5 apresentou o IB como campo educativo em que prioriza-se o ensino da música, sua estrutura e organização, os princípios pedagógicos-musicais que orientam as atividades. Verificou-se que o projeto, por meio da educação musical, com o ensino de percussão corporal e de outros instrumentos oferecidos, contribui para a transformação social dos atendidos. As práticas pedagógicas-musicais são desenvolvidas por todos, educadores e multiplicadores do IB. Eles são preparados e formados a cada encontro, na reunião pedagógica, nos ensaios, nas apresentações artísticas, são capacitados para resolver conflitos no dia a dia, como a falta de recursos para o projeto, por exemplo. O espaço IB contribui significativamente para a educação cultural de crianças e adolescentes que não têm acesso fácil a esse tipo de educação. O projeto disponibiliza aos alunos o acesso à percussão corporal e a aulas de instrumento. 


\section{CONSIDERAÇÕES FINAIS}

A pesquisa se concentrou no Instituto Batucar, que se define como um espaço educativo na modalidade não formal, em que a percussão corporal é o fio condutor dos objetivos de inclusão e transformação social. Além das práticas musicais, o projeto ajuda no desenvolvimento da autoestima dos alunos e promove a inclusão social e a cidadania. A sustentabilidade do projeto envolve a formação de multiplicadores, que se comprometem com os objetivos da instituição e participam de reuniões pedagógicas. A aprendizagem docente é contínua e ocorre na prática e para a prática.

A pesquisa teve como objetivo geral compreender a atuação dos multiplicadores no Instituto Batucar e, para que atingisse esse objetivo, foi adotada uma abordagem qualitativa com entrevistas semiestruturadas individuais e coletivas com observação participante. $\mathrm{O}$ contato direto com o IB e seus multiplicadores possibilitou compreender como o educador social se forma e atua no projeto, o que trouxe respostas para os objetivos específicos da pesquisa que foram: descrever e analisar as práticas musicais desenvolvidas no Instituto Batucar; identificar as estratégias pedagógico-musicais dos multiplicadores; e conhecer como os multiplicadores percebem sua atuação no projeto.

Ao analisar as práticas musicais desenvolvidas no projeto, foi possível observar que as aulas são em grupo e, em círculo, os alunos aprendem por meio da observação e da imitação, tendo como referência o educador que está orientando os exercícios. A prática tem como fio condutor a percussão corporal, por meio da qual os alunos aprendem vários ritmos que utilizam para tocar instrumentos musicais. No Instituto, além das aulas de percussão corporal, são oferecidas aulas de violão, violoncelo, violino, canto, além de aulas de orquestra com um maestro e ensaios do grupo de performance.

Além das aulas de música no projeto, acontecem semanalmente atividades como reuniões pedagógicas e organização do espaço, como limpeza e manutenção de instrumentos musicais. Nas reuniões pedagógicas são discutidas as aulas com os educadores e os multiplicadores. O coordenador os orienta, esclarecendo dúvidas, oferecendo dicas e conversando sobre as práticas do ensino da música no Instituto. Nessas reuniões, todos são informados quanto a passeios e apresentações artísticas, além de participarem de discussões a respeito do planejamento futuro do projeto, que envolvem temas como a aquisição de recursos para a manutenção e continuação das atividades, por exemplo. Na mesma reunião é decidido o dia da limpeza do espaço e o que precisa ser feito. 
A reunião pedagógica no Instituto Batucar é chamada pelos educadores de "a mesa". Nela, além das discussões sobre os processos pedagógicos e partilhas das vivências no local, é enfatizada pelo coordenador do Instituto a liderança dos multiplicadores no projeto. Os multiplicadores são orientados a participar do Instituto, a se apropriar do Instituto não somente como aprendizes, mas como futuros coordenadores do projeto, futuros líderes, capazes de assumir compromissos que exigem maiores responsabilidades. Os multiplicadores são constantemente incentivados a liderar, tanto que em cada reunião um dos multiplicadores é escolhido para coordenar o momento.

Ao identificar as estratégias pedagógico-musicais dos multiplicadores, foi possível perceber que eles atuam auxiliando os educadores nas aulas no projeto e na escola pública situada na mesma comunidade. No Instituto Batucar eles auxiliam nas aulas, principalmente, aqueles alunos que apresentam maiores dificuldades nos instrumentos, organizam os alunos em grupos e repassam orientações da forma que aprenderam no Instituto Batucar. A sua atuação na escola é marcada por desafios pois estão no início de sua atuação como educadores e ainda têm pouca experiência na gestão de sala de aula. Fica evidente a dificuldade em lidar com a disciplina dos alunos, uma vez que eles apresentam comportamento distinto dos alunos no Instituto Batucar. No Instituto Batucar os valores de respeito mútuo e de colaboração são trabalhados no dia a dia, os alunos já têm consciência do que se pode e do que não se pode fazer ou falar. Na escola, esses valores precisam ser construídos, o que exige a aquisição de saberes relacionados a interação e a formação cidadã. Assim, apesar dos "multiplicadores" priorizarem a educação vivenciada no IB como a ideal, como aquela que vai fazer diferença na vida dos alunos, a escola demanda outras estratégias e uma forma de condução das atividades que é aprendida na experiência direta na sala de aula e no contato com os alunos.

A aprendizagem docente dos multiplicadores, tanto no Instituto Batucar como na escola, é sistematizada e discutida nas reuniões pedagógicas quando eles expressam suas dificuldades e refletem sobre as suas ações, decisões e sucessos ao dar aulas na escola e no IB. As estratégias pedagógico-musicais dos multiplicadores são orientadas pelos integrantes do IB nessas reuniões. Eles conduzem os multiplicadores a uma gestão participativa, onde todos fazem parte do Instituto e se apropriam desse espaço, considerando-o como um laboratório de aprendizagem. Na pesquisa foi possível verificar a importância da aprendizagem colaborativa, manifestada na alegria dos educadores e dos alunos e no prazer em compartilhar os conhecimentos produzidos e adquiridos juntos. O cotidiano no projeto, o ser aluno e ser professor, é considerado por todos como um grande laboratório de aprendizagem docente. 
Ao conhecer como os multiplicadores percebem sua atuação no projeto fiquei surpresa em observar que alguns deles não diferenciam o aprender do ensinar. Esse sentimento está relacionado com a forma como o coordenador do IB conduz as atividades no projeto. O fato de não diferenciar o ser aluno do ser multiplicador é algo natural no Instituto, não é estranho para os integrantes do IB. Em sua atuação, todos os educadores se consideram aprendizes.

Isso demostra no projeto o educador não é centro, ou o mais importante no processo pedagógico musical, ou seja, o dono do saber. No Instituto Batucar, formam-se pessoas que sabem compartilhar conhecimentos, ideias. São orientadores, profissionais capazes de trabalhar os valores humanos com os alunos, pessoas que não são apenas multiplicadores, mas são amigos, são alunos dispostos a compartilhar seus saberes e suas experiências.

O Instituto Batucar orienta os multiplicadores para promoverem a cidadania e a transformação social, por meio das ações pedagógicas tendo a música como um meio, valorizando o ser humano como parte do projeto como é o caso dos multiplicadores. O projeto multiplicadores promove a cidadania, proporciona ao jovem a oportunidade de ter experiências no ensino da música e acompanha sua trajetória com orientações que o preparam para a vida profissional, assim como vocacional.

A partir dessas conclusões, considerei ter contribuído para futuros estudos sobre a educação musical no contexto dos projetos sociais. Os dados podem fomentar as discussões sobre a formação de professores para atuar em projetos sociais, contribuindo para o campo da educação não formal. As estratégias pedagógicas desenvolvidas no IB podem também contribuir para a formação de educadores, principalmente, no que se refere a experiência prática e a aprendizagem docente no contato direto com o fazer musical.

Alguns temas sobre os quais tenho refletido, no decorrer do trabalho podem ser questões possíveis para a realização de outras pesquisas. Entre eles, a investigação da profissionalização e continuidade da profissão como professor de música no projeto ou em outros locais. Pode-se questionar até que ponto a música como profissão acompanha os multiplicadores em sua trajetória futura, ou o que os leva a continuarem trabalhando como professores de música, como isso acontece e qual a influência que sua formação como professores no projeto pode ter em sua vida profissional. 


\section{REFERÊNCIAS BIBLIOGRÁFICAS}

ALMEIDA, Cristiane Maria Galdino. Educação não-formal e atuação profissional: Um survey em oficinas de música em Porto Alegre - RS. 2005. 168 f. Dissertação (Mestrado) Universidade Federal do Rio Grande do Sul, Porto Alegre, 2005.

ALVES-MAZZOTTI, Alda Judith. Usos e Abusos dos Estudos de Caso. Programa de PósGraduação em Educação, Universidade Estácio de Sá - Rio de Janeiro. Cadernos de Pesquisa, Rio de Janeiro, v. 36, n. 129, p. 637-651, set./dez. 2006. Disponível em: <www.scielo.br/pdf/cp/v36n129/a0736129.pdf>. Acesso em: 25mar. 14.

ANDRADE, Miriam Gomes Vieira de. Organizações do Terceiro Setor: Estratégias para Captação de Recursos junto às empresas privadas. 2002. 146 f. Dissertação (Mestrado em Engenharia de Produção) - Universidade Federal de Santa Catarina, Florianópolis, 2002.

ANDRÉ, Marli Eliza D. A. de. Etnografia da Prática Escolar. 5ª Ed. São Paulo: Papirus, 2000.

ARROYO, Margarete (org). Jovens e músicas: Um guia bibliográfico. São Paulo: Unesp, 2013.

ASHOKA EMPREENDEDORES SOCIAIS; MCKINSEY \& COMPANY, Inc.

Empreendimentos sociais sustentáveis: como elaborar planos de negócio para organizações sociais. São Paulo: Petrópolis, 2001.

AZEVEDO, Maria Cristina de Carvalho Cascelli de. Os Saberes Docentes na Ação

Pedagógica dos Estagiários de Música: Dois estudos de Caso. 2007. 449 f. Tese (Doutorado em Música) - Universidade Federal do Rio Grande do Sul, Porto Alegre, 2007.

BARBATUQUES. Fernando Barba. Barbatuques.

Disponível em: <http://barbatuques.com.br/pt/>.

Acesso em 25 nov. 2014

BARBOSA, Luiz Gustavo M. Os impactos econômicos do turismo e sua implicação nas políticas públicas: o caso do município de Macaé-RJ, Brasil. In: VII Congreso Internacional del CLAD sobre la Reforma del Estado y de la Administración Pública. Lisboa, Portugal, 8-11 Oct. 2002.

BARBOSA, Neide dos Santos. Educação musical no projeto social: desafios e possibilidades. In: XX CONGRESSO NACIONAL DA ASSOCIAÇÃO BRASILEIRA DE EDUCAÇÃO MUSICAL. Anais. Vitória: ABEM, nov. 2011, p. 877-885.

BOGDAN, Robert; BIKLEN, Sari. Investigação qualitativa em Educação: fundamentos, métodos e técnicas. In: Investigação qualitativa em educação. Portugal: Porto Editora, 1994, p. 15-80.

BRASIL, Presidência da República. Lei Federal no 8069, de 13 de julho de 1990. Dispõe sobre o Estatuto da Criança e do Adolescente e dá outras providências. Diário Oficial da União, Brasília, DF, 16 jul. 1999. Disponível em:

$<$ http://www.planalto.gov.br/ccivil_03/leis/18069.htm>. Acesso em: 17jun. 2013. 
BRASIL, Presidência da República. Lei Federal n ${ }^{\circ}$ 9.790, de 23 de março de 1999. Dispõe sobre a qualificação de pessoas jurídicas de direito privado, sem fins lucrativos, como Organizações da Sociedade Civil de Interesse Público, institui e disciplina o Termo de Parceria, e dá outras providências. Diário Oficial da União, Brasília, DF, 24 mar. 1999. Disponível em: < http://www.planalto.gov.br/ccivil_03/leis/19790.htm>. Acesso em: 23 mar. 2013.

CALLEGARI, Paula Andrade. A relação indivíduo-música na perspectiva dos significados musicais de Lucy Green: um estudo de caso em um projeto social. 2008. 139 f. Dissertação (Mestrado em Música) - Universidade de Brasília, Brasília, 2008.

CIAVATTA, Lucas. O Passo. Música e Educação.

Disponível em:<http://www.opasso.com.br/>.

Acesso em: 30 set. 2014.

. O Passo. Apostila de curso.

Disponível em: <http://www.ufpi.br/arquivos/File/Editais\%202013/ApostiladeCurso.pdf>. Acesso em: 12 set. 2014.

COHEN, Louis; MANION, Lawrence. Research Methods in Education. Fourth edition. London and New York: RoutledgeFalmer, 1997.

CORTELLA, Mário Sérgio. Aprendendo na escola e na ONG. In: Muitos Lugares para Aprender (2002) - Centro de Estudos e Pesquisas em Educação, Cultura e Ação Comunitária - CENPEC - São Paulo; CENPEC / Fundação Itaú Social / Unicef, 2003.

CRUVINEL, Flávia Maria. Educação Musical e Transformação Social: uma experiência com o ensino de cordas. Goiânia: Instituto Centro-Brasileiro de Cultura, 2005. 255 p.

DIAS, Cláudia Augusto. Grupo Focal: técnica de coleta de dados em pesquisas qualitativas. Informação \& Sociedade: Estudos, Universidade Federal da Paraíba. Programa de Pós-Graduação em Ciência da Informação, v. 10, n. 2, 2000. Disponível em: $<$ v.10 n.2 2000 > <http://periodicos.ufpb.br/ojs/index.php/ies/article/view/330/252>. Acesso em: 21jul. 2014

DIEESE. Pesquisa Socioeconômica em Territórios de Vulnerabilidade Social no Distrito Federal. Fev. 2011. Disponível em: <http://www.dieese.org.br/dieese/projetos/SEDEST/ pesquisaSocioeconomica SEDEST/produto6.pdf>. Acesso em: abr. 2014.

DUSILEK, Darci. A arte da Investigação Criadora. Introdução à Metodologia da Pesquisa. 8 a ed. Rio de Janeiro: JUERP, 1986.

FERRAREZI, Elisabete; REZENDE, Valéria. OSCIP - Organização da sociedade civil de interesse público: a Lei 9.790/99 como alternativa para o terceiro setor. Brasília: Comunidade Solidária, 2001. 108 p.

FLEURY, Heloisa Junqueira; MARRA, Marlene Magnabosco. Intervenção Grupal na Educação. São Paulo Editora: Agora, 2005.

FRANCO, Maria Amélia do Rosário Santoro. Pedagogia como ciência da educação. $2^{\mathrm{a}}$ Ed. Ver. Ampl.- São Paulo: Cortez, 2008. 
FREIRE, Paulo. Pedagogia da autonomia: saberes necessários à prática educativa. $43^{\mathrm{a}}$ ed. São Paulo: Paz e Terra, 2011.

. Pedagogia do Oprimido. Rio de Janeiro: Paz e Terra, 1987.

GADOTTI, Moacir. A questão da educação Formal/não-formal. INSTITUT

INTERNATIONAL des DROITS de L'ENFANT (IDE). Sion (Suisse), 18 au 22 octobre 2005. Disponível em: <http://www.virtual.ufc.br/solar/aula_link/llpt/A_a_H/estrutura_politica _gestao_organizacional/aula_01/imagens/01/Educacao_Formal_Nao_Formal_2005.pdf>. Acesso em: 28set. 2014.

GARCÍA. Carlos Marcelo. La profesión docente en momentos de cambios. ¿Qué nos dicen los estudios internacionales? ESTUDIOS E INVESTIGACIONES. In:

CEE Participación Educativa, nº 16, p. 49-68, marzo 2011.

GIL, Antônio Carlos. Como Elaborar Projetos de Pesquisa. $4^{\text {a }}$ Ed. São Paulo: Atlas, 2002.

GOHN, Maria da Glória. Educação não formal e o educador social: atuação no desenvolvimento de projetos sociais. São Paulo: Cortez, 2010.

HIKIJI, Rose Satiko Gitirana. A Música e o Risco. Etnografia da Performance de Crianças e Jovens Participantes de um Projeto Social de Ensino Musical. São Paulo: Editora Universidade de São Paulo, 2006. 256 p.

INSTITUTO BATUCAR. Batucadeiros Oficina de Percussão Corporal Capacitação para Educadores. Módulo I. Apostila, 21 p/ 2013.

Instituto Batucar. Disponível em:

$<$ http://www.institutobatucar.org.br/005/00502001.asp?ttCD_CHAVE=14935)>.

Acesso em: 21 mar. 2013.

KLEBER, Magali O. Educação musical: novas ou outras abordagens - novos ou outros protagonistas. Revista da ABEM, Porto Alegre, v 14, n ${ }^{\circ}$ 14, p. 91-98, 2006 a.

- A Rede de Sociabilidade em Projetos Sociais e o processo pedagógico-musical. Revista ABEM, Londrina, v. 19, nº 26 p. 37-46, jul./dez. 2011b.

- A prática da educação musical em OnGs: dois estudos de caso no contexto urbano Brasileiro. 2006. 334f. Tese (Doutorado em Música), Universidade Federal do Rio Grande do Sul, Porto Alegre, 2006c.

- Educação Musical e ONGs: dois estudos de caso no contexto Urbano Brasileiro.Em Pauta, v. 17, no 29, p. 113-138, jul./dez., 2006d. Disponível em $<$ http://www.ufrgs.br/cotidiano/fl_adm/uploads/fck/youblisher_com-885788Educa_o_musical_e_ONGs_dois_estudos_de_caso_no_contexto_urbano_brasileiro.pdf>. Acesso em: 21 out. 2012.

LUDKE, Menga; ANDRÉ, Marli E. D. A. Pesquisas em educação: abordagens qualitativas. São Paulo: Ed. Pedagógica e Universitária, 1986. 99 p. 
MARTINEZ, Andréia Pereira de Araújo. "O que é, o que é?" Princípios Norteadores para uma prática educativa de atividade musical com crianças. 2013. 150 f. Dissertação (Mestrado) - Universidade de Brasília - Faculdade de Educação, Brasília, 2013.

MEDEIROS, Maria Augusta dos Santos. Relações entre a professora de música e os alunos-presidiários: um estudo de caso etnográfico em Santa Maria - RS. 2009. 1v. 153 p. Dissertração (Mestrado). Universidade Federal de Santa Maria - Educação, Santa Maria, 2009.

MENEZES, Evandro Carvalho de. A Educação Musical na ONG Corpo Cidadão. Dissertação (Mestrado em Música). 2009. 162 p. Universidade Federal de Minas Gerais, Escola de Música, Belo Horizonte, 2009.

MONTANDON, Maria Isabel. Perguntas que respondem: preparando o entrevistador para a pesquisa qualitativa. In: CONGRESSO NACIONAL DA ABEM, n. 28, 2008, Salvador. Anais. Salvador: UFBA, 2008. p. 341-343.

MORANDI, Franc. Introdução à Pedagogia. São Paulo: Ática, 2008. 136 p.

MOSKOVICS; Jenny Milner. CALVETTI; Prisla Ücker. Formação de Multiplicadores para a Prevenção das DST/ AIDS numa Universidade Espanhola.Psicologia Ciência e Profissão, v. 1, no 28, p. 210-217. 2008. Disponível em:

$<$ http://pepsic.bvsalud.org/pdf/pcp/v28n1/v28n1a16.pdf $>$.

Acesso em: 03 nov. 2014.

NETO, João Clemente de Souza. Pedagogia Social: A Formação do Educador Social e seu Campo de Atuação. In: Cadernos de Pesquisa em Educação PPGE-UFES. Vitória, v.16, n. 32, jul./dez. 2010, p. 29-64.

OLIVEIRA, Cristiane Gomes de; MORAIS, Jacqueline de Fátima dos Santos; BRAUN, Patrícia. Rodas em sala de aula: alguns aspectos relativos ao ensino e aprendizagem no cotidiano do Ensino Fundamental. In: Cadernos do Aplicação. Porto Alegre, v. 23, n. 1, jan./jun. 2010.

PEDROSO, Sandra Helena Gonzaga; ROCHA, Marcius Hollanda Pereira da. Projetos Sociais com Foco no Sistema de Gestão. In: VI Congresso Nacional de Excelência em Gestão, 2010. Anais. Niterói, RJ, 5-7 ago. 2010, p. 01-16.

PENNA, Maura; BARROS, Olga Renalli Nascimento; MELLO, Marcel Ramalho. Educação musical como função social: qualquer prática vale? Revista da ABEM. Londrina, v 20, n. 27 , p. $65-78$, jan/jun. 2012.

SOUZA, Jussamara. Educação Musical e práticas sociais. In: Revista da ABEM. Porto Alegre, n. 10, p. 07-11, mar. 2004.

STEPHANOU, Luis; MULLER, Lúcia Helena; CARVALHO, Isabel Cristina de Moura. Guia para a elaboração de projetos sociais. Porto Alegre: Ed Sinodal e Fundação Luterana de Diaconia, 2003. 
TORRES, Grace. O Projeto Canja da Viola: uma comunidade de prática musical. 2008. 114 f. Dissertação (Mestrado em Programa de Pós-Graduação em Música) - Universidade Federal do Paraná, Curitiba, 2008.

UNESCO. Inclusão Social no Brasil. S/d a. Disponível em:

$<$ www.unesco.org/new/pt/brasilia/social-and-human-sciences/social-inclusion/ $>$.

Acesso em 28 abr. 2014.

- Direitos Humanos no Brasil. S/D b. Disponível em:

$<$ www.unesco.org/new/pt/brasilia/social-and-human-sciences/human-rights/>.

Acesso em 28 abr. 2014.

Disponível em:

. Sobre a Representação da UNESCO no Brasil. S/D c.

$<$ www.unesco.org/new/pt/brasilia/about-this-office/>.

Acesso em 28 abr. 2014.

VALLADARES, Licia. Os dez mandamentos da observação participante. Rev. bras. Ci.

Soc., São Paulo, v. 22, n. 63, Feb. 2007. Disponível em: <http://www.scielo.br/scielo.php? script=sci_arttext\&pid=S0102-69092007000100012\&lng=en\&nrm=iso $>$. Acesso em: 17 jul. 2014. 
APÊNDICES 


\title{
APÊNDICE A - Carta de apresentação de pesquisadora
}

\author{
À direção/Coordenadores/Administração do Instituto Batucar \\ Prezados
}

Venho por meio desta, encaminhar mestranda Josilaine de Castro Gonçalves, matrícula 120178982, do curso de Mestrado em Música do Programa de Pós-graduação Música em Contexto do Departamento de Música da Universidade de Brasília, solicitar autorização para que a pesquisadora possa realizar pesquisa de campo nesse Instituto com fins de coletas de dados para sua Dissertação de Mestrado. A pesquisa intitulada “TODO MUNDO APRENDE, TODO MUNDO ENSINA": O PROJETO MULTIPLICADORES DO INSTITUTO BATUCAR visa compreender o processo de aprender a ensinar no contexto do projeto, considerando a voz dos seus profissionais, professores, monitores ou multiplicadores. Nesse sentido, a mestranda necessita entrevistar representantes da administração, coordenadores, professores e multiplicadores, bem como filmar as atividades pedagógico-musicais. É importante destacar que o nome dos sujeitos participantes da pesquisa não será identificado preservando o anonimato dos participantes.

Colocamo-nos à disposição para quaisquer esclarecimentos

Agradeço a atenção dispensada com a pós-graduanda,

Atenciosamente,

Brasília, 18 de novembro de 2013

Maria Cristina de Carvalho Cascelli de Azevedo (151815)

Tel: 91191319 / 31071110 


\section{APÊNDICE B - Carta de solicitação de autorização para observação e filmagem}

À direção da escola Centro de Ensino Fundamental 113

Prezada diretora,

Eu, Josilaine de Castro Gonçalves, matrícula UnB: 120178982, mestranda do Programa de Pós-graduação Música em Contexto da Universidade de Brasília, sob orientação da prof ${ }^{\mathrm{a}}$ Dr $^{\mathrm{a}}$ Maria Cristina de Carvalho Cascelli de Azevedo, venho por meio desta, solicitar autorização para observar e filmar as aulas de música que os Batucadeiros ministram neste estabelecimento de ensino, nas turmas do Ensino Fundamental, durante os meses de novembro e dezembro. As observações e filmagens fazem parte da coleta de dados de minha pesquisa de mestrado, que tem por objetivo investigar a atuação dos multiplicadores do Instituto Batucar. As gravações serão utilizadas somente com fins acadêmicos e científicos (apresentação em congressos e palestras acadêmicas) e didáticos (arquivo de vídeos).

Nesse sentido, solicito permissão para a realização dessa atividade e me coloco a disposição para possíveis esclarecimentos.

Atenciosamente, 


\section{APÊNDICE C - Carta de cessão de direito}

\section{CARTA DE CESSÃO DE DIREITO}

$\mathrm{Eu}$, casado(a), carteira de identidade número
que cedo os direitos de minhas entrevistas gravadas nos dias , ( ) solteiro(a), ( )

transcritas e revisadas por mim, para Josilaine de Castro Gonçalves, matrícula UnB: 120178982, carteira de identidade número 2014270/SSP-DF, podendo as mesmas ser utilizadas integralmente ou parcialmente, sem restrições de prazos e citações, desde a presente data. Da mesma forma, autorizo o uso das citações desde que a minha identidade seja mantida em sigilo.

Abdicando igualmente dos direitos dos meus descendentes sobre a autoria das ditas entrevistas, subscrevo o presente documento.

Data:

Assinatura 


\section{APÊNDICE D - Autorização de participação de menor em entrevista}

\section{AUTORIZAÇÃO}

Autorizo meu filho a

participar da entrevista organizada pela mestranda Josilaine de Castro Gonçalves, matrícula UnB: 120178982, como parte de sua pesquisa de mestrado pelo Programa de Pós-Graduação Música em Contexto da Universidade de Brasília - UnB. Autorizo também a utilização das gravações e imagens obtidas pela mestranda para fins de registro e trabalhos acadêmicos.

A pesquisadora deverá preservar a identidade de todos os alunos participantes dos grupos de entrevistas, não mencionando seus nomes durante a análise dos dados.

Idade do aluno:

Grau de parentesco do responsável:

Brasília, de Novembro de 2013. 


\section{APÊNDICE E - Roteiro para entrevista (Coordenador)}

O INSTITUTO BATUCAR (Origem, atualidade/Princípios, perspectivas)

1 - Como começou o Instituto Batucar?

2 - Como era a estrutura organizacional? (Quantidade de professores, voluntários, alunos, recursos didáticos...).

3 - Como eram as aulas? (Metodologia)

4 - Fale sobre as facilidades que você encontrava no Instituto Batucar.

5 - Fale sobre as dificuldades que você encontrava no Instituto Batucar.

6 - Qual era a sua perspectiva sobre o impacto que o Instituto Batucar causaria nas crianças atendidas?

7 - Ao perceber as atividades acontecendo quais os resultados você percebia nas crianças atendidas?

\section{OBJETIVOS/PRINCÍPIOS}

1 - Quais são os objetivos do Instituto Batucar?

2 - Que princípios educacionais e musicais o Instituto Batucar adota?

3 - Como esses princípios são trabalhados com os alunos?

4 - Como eles respondem?

ATUAL

1 - Que tipo de mudanças tem ocorrido no Instituto Batucar?

3 - Como o aluno se torna multiplicador?

2 - Qual o papel dos multiplicadores no Instituto Batucar? Quando, onde e como atuam?

4 - Como os multiplicadores são formados?

5 - Qual a contribuição que eles oferecem ao Instituto Batucar?

6 - Como você percebe a passagem dos alunos aprendiz para professor?

7 - Quais as facilidades e quais as dificuldades que eles apresentam durante esse processo de transição? (aprendiz/professor)

8 - Como são resolvidos/trabalhados/explorados as dificuldades e facilidades dos multiplicadores? 
1 - Como é realizada a preparação das aulas? Como são avaliadas? O que deu certo? O que não deu?

2 - Explique mais a metodologia utilizada nas aulas, baseia em método? Desenvolve procedimentos próprios?

3 - Quais são as suas influências no Instituto Batucar, suas fontes?

\section{PROFESSOR/ MULTIPLICADORES}

1 - O que é ser um professor/ multiplicador no Instituto Batucar?

2 - Quais as características observadas de um aluno que poderá ser um multiplicador?

3 - Qual a diferença entre o professor de música e o multiplicador no Instituto Batucar?

Quais? Por quê?

4 - Quem são os professores/multiplicadores (quantidade) no Instituto Batucar?

5 - Que critérios são utilizados para a contratação de professor?

6 - Quando o multiplicador se torna um professor dentro do Instituto?

7 - O multiplicador é importante para o Instituto Batucar? Por quê?

Como é feita a remuneração professor/multiplicador?

8 - Como é feito o trabalho individual e coletivo no Instituto Batucar?

\section{APRESENTAÇÕES}

1 - Como os alunos são preparados para as apresentações?

2 - Como os alunos respondem a esse processo?

3 - Qual a sua expectativa antes e durante as apresentações?

4 - Que comportamentos eles apresentam durante esse processo?

5 - Que característica principal você percebe nos alunos durante uma apresentação?

6 - O que eles comentam depois de uma apresentação?

7 - Como esse momento é visto pelo Instituto Batucar?

\section{PERSPECTIVAS}

1 - Quais são os projetos para o futuro do Instituto Batucar?

2 - Gostaria de mudar algo no Instituto Batucar? O que? E Por quê? 


\section{APÊNDICE F - Roteiro para entrevista (Coordenadora Pedagógica)}

O INSTITUTO BATUCAR (Origem, atualidade/Princípios, perspectivas)

1 - Conte sua trajetória no projeto.

2 - Qual o seu papel no Instituto Batucar?

3 - Conte como eram as aulas? (Metodologia)

4 - Fale sobre os pontos fortes que você encontrava no Instituto Batucar.

5 - Fale sobre os pontos fracos que você encontrava no Instituto Batucar.

6 - Qual era a sua perspectiva sobre o impacto que o Instituto Batucar causaria nas crianças atendidas?

7 - Ao perceber as atividades acontecendo quais os resultados você percebia nas crianças atendidas?

\section{ATUAL}

1 - Como você vê as mudanças que tem ocorrido no Instituto Batucar?

3 - Como você vê o aluno que se torna um multiplicador?

4 - Como você percebe a passagem dos alunos aprendiz para professor?

5- Quais os pontos fortes e quais os pontos fracos que eles apresentam durante esse processo de transição? (aprendiz/professor)

6 - Como são resolvidos/trabalhados/explorados os pontos fracos e os pontos fortes dos multiplicadores?

\section{AULA}

1 - Como é realizada a preparação das aulas? Como são avaliadas? O que deu certo? O que não deu?

2 - Como você percebe a metodologia utilizada nas aulas, baseia em método? Os procedimentos que são desenvolvidos?

3 - Quais são as suas influências no Instituto Batucar, suas fontes?

\section{PROFESSOR/ MULTIPLICADORES}

1 - Na sua visão o que é ser um professor/ multiplicador no Instituto Batucar?

2 - Quais as características que você observa em um aluno que poderá ser um multiplicador? 
3 - Você percebe a diferença entre o professor de música e o multiplicador no Instituto Batucar? Quais? Por quê?

4 - Como você vê a importância do multiplicador para o Instituto Batucar? Por quê?

5 - Como é feito o trabalho individual e coletivo pelos professores no Instituto Batucar?

\section{APRESENTAÇÕES}

1 - Como você percebe a preparação dos alunos para as apresentações?

3 - Qual a sua expectativa antes e durante as apresentações?

4 - Como você percebe os comportamentos que os alunos apresentam durante esse processo?

5 - Que característica principal você percebe nos alunos durante uma apresentação?

\section{PERSPECTIVAS}

1 - Quais são os projetos para o futuro dentro do Instituto Batucar?

2 - Gostaria de mudar algo no Instituto Batucar? O que? E Por quê? 


\section{APÊNDICE G - Roteiro para entrevista (Administrador)}

I ATIVIDADE COMO ADMINISTRADOR: entrada e contato com o projeto.

1- Como administrador, quais são suas atividades no Batucar?

2 - Conte como foi seu primeiro contato com o projeto e como começou e tem sido sua participação como administrador?

3 - Que mudanças foram realizadas no projeto desde o início da sua participação? Por quê? Até que ponto essas mudanças foram positivas para o projeto?

4 - Como você vê a estrutura e organização do projeto? O que funciona melhor e por quê? O que você acha que precisa ser modificado?

II O PROJETO BATUCAR - desafios e avanços

1- Para você quais são os pontos fortes e fracos do Batucar?

2- Para você quais são os desafios de administrar um projeto social em música como o Batucar?

\section{CONCEPÇÕES E PERCEPÇÃO SOBRE O PROJETO}

1- Para você qual o principal objetivo do projeto?

2 -Na sua opinião, qual a contribuição do projeto para a vida dos alunos?

3- Na sua opinião, quais são as perspectivas futuras para o projeto? O que você mudaria ou não mudaria?

4- O que você tem aprendido como administrador do projeto?

5 -Fique livre para acrescentar mais alguma informação ou esclarecimento. 


\section{APÊNDICE H - Roteiro para entrevista (Educadores de música)}

O INSTITUTO BATUCAR (Origem, atualidade/Princípios, perspectivas)

1 - Conte sua trajetória no projeto.

2 - Qual o seu papel no Instituto Batucar?

3 - Conte como eram as aulas? (Metodologia)

4 - Fale sobre os pontos fortes que você encontrava no Instituto Batucar.

5 - Fale sobre os pontos fracos que você encontrava no Instituto Batucar.

6 - Qual era a sua perspectiva sobre o impacto que o Instituto Batucar causaria nas crianças atendidas?

7 - Ao perceber as atividades acontecendo quais os resultados você percebia nas crianças atendidas?

\section{ATUAL}

1 - Como você vê as mudanças que tem ocorrido no Instituto Batucar?

3 - Como você vê o aluno que se torna um multiplicador?

4 - Como você percebe a passagem dos alunos aprendiz para professor?

5- Quais os pontos fortes e quais os pontos fracos que eles apresentam durante esse processo de transição? (aprendiz/professor)

6 - Como são resolvidos/trabalhados/explorados os pontos fracos e os pontos fortes dos multiplicadores?

\section{AULA}

1 - Como é realizada a preparação das aulas? Como são avaliadas? O que deu certo? O que não deu?

2 - Como você percebe a metodologia utilizada nas aulas, baseia em método? Os procedimentos que são desenvolvidos?

3 - Quais são as suas influências no Instituto Batucar, suas fontes?

\section{PROFESSOR/ MULTIPLICADORES}

1 - Na sua visão o que é ser um professor/ multiplicador no Instituto Batucar?

2 - Quais as características que você observa em um aluno que poderá ser um multiplicador? 
3 - Você percebe a diferença entre o professor de música e o multiplicador no Instituto Batucar? Quais? Por quê?

4 - Como você vê a importância do multiplicador para o Instituto Batucar? Por quê?

5 - Como é feito o trabalho individual e coletivo pelos professores no Instituto Batucar?

\section{APRESENTAÇÕES}

1 - Como você percebe a preparação dos alunos para as apresentações? Qual a importância das apresentações para o projeto?

2 - Qual a sua expectativa antes e durante as apresentações?

3 - Como você percebe os comportamentos que os alunos apresentam durante esse processo?

Como os alunos reagem a apresentação antes, durante e depois das apresentações.

4- Que característica principal você percebe nos alunos durante uma apresentação?

\section{PERSPECTIVAS}

1 - Quais são os projetos para o futuro dentro da sua aula no Instituto Batucar?

2 - Gostaria de mudar algo na sua aula que ainda não conseguiu? O que? E Por quê? 


\section{APÊNDICE I - Roteiro para entrevista focal com os Multiplicadores do Instituto}

\section{Batucar}

\section{APRENDER/ENSINAR}

1. O que vocês acham que é aprender percussão corporal?

2. Como vocês aprenderam? (percussão corporal/violão...)

3. Como se ensina percussão corporal?

4. Percussão corporal é música?

5. Na aula de Percussão Corporal em que se deve prestar atenção?

6. Olha o pessoal disse que aprender Percussão Corporal é ter bastante coordenação motora. $\mathrm{O}$ que vocês pensam sobre isso?

( )concordo ( ) concordo parcialmente ( ) não concordo

\section{A PRÁTICA EM SALA DE AULA}

1. Quem aqui pode falar como é uma aula de Percussão Corporal/violão?

2. Agora me diz o que vocês acham?

3. Quando vocês estão em sala de aula, os alunos todos aprendem com facilidade?

4. Como é ensinar na escola? Ensinar é difícil? Quem concorda e porque?

5. Como vocês se tornaram multiplicadores?

6. Qual é a postura do professor para ensinar? Como ele deve fazer?

7. Porque vocês vieram para o Instituto Batucar e porque continuam? Eu queria ouvir a história de cada um como multiplicador.

8. "Eu me sinto professor." Como é isso? Para ensinar é preciso pensar em ensinar?

9. Quem aqui se sente professor e por quê?

10. Porque eu ensino os alunos aprendem? 